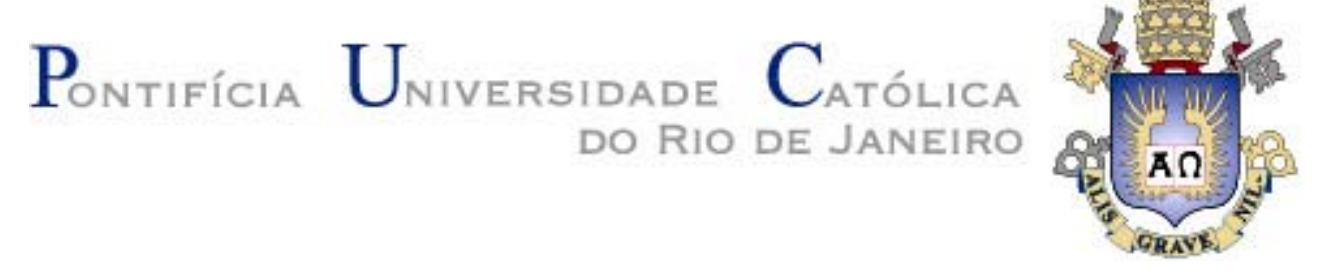

Florence Vidal Perfeito

Variações em Rotinas Organizacionais:

O Caso de um Instituto de Tecnologia e Inovação

Dissertação de Mestrado

Dissertação apresentada ao Programa de Pósgraduação em Administração de Empresas da PUCRio como requisito parcial para obtenção do título de Mestre em Administração de Empresas

Orientadora: Profa. Sandra Regina da Rocha-Pinto

Rio de Janeiro

Abril / 2016 


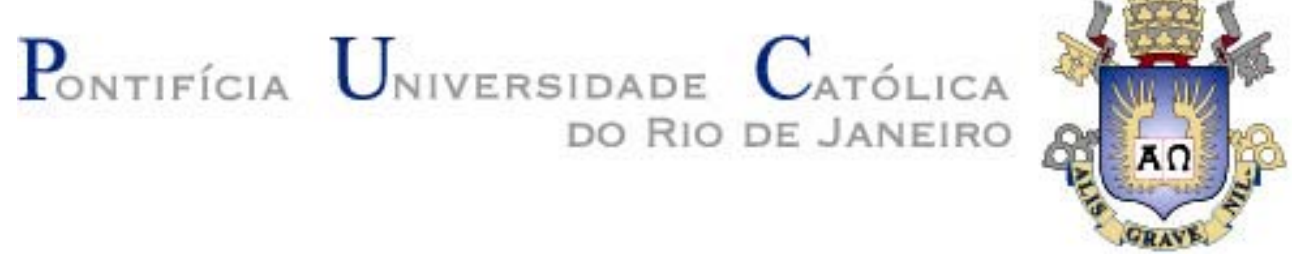

Florence Vidal Perfeito

\title{
Variações em Rotinas Organizacionais: o \\ Caso de um Instituto de Tecnologia e Inovação
}

Dissertação apresentada como requisito parcial para obtenção do grau de Mestre pelo Programa de PósGraduação em Administração de Empresas do Departamento de Administração da PUC-Rio. Aprovada pela Comissão Examinadora abaixo assinada.

\author{
Profa. Sandra Regina da Rocha Pinto \\ Orientadora \\ Departamento de Administração - PUC-Rio \\ Profa. Andrea Cherman \\ Departamento de Administração - PUC-Rio
}

Prof. Lincoln Silva Gomes

Centro de Tecnologia Senai - Solda

Profa. Mônica Herz

Vice-Decana de Pós-Graduação do CCS - PUC-Rio

Rio de Janeiro, 07 de abril de 2016 
Todos os direitos reservados. É proibida a reprodução total ou parcial do trabalho sem autorização da universidade, da autora e da orientadora.

Florence Vidal Perfeito

Graduada em Administração com ênfase em Marketing, pela ESPM-RJ, e Pós-Graduada em Gestão de Negócios com foco em Sustentabilidade, pela Universidade Federal Fluminense, com vivência internacional na Braunschweig University of Technologye, na Alemanha. Desde 2003 atua em projetos de planejamento e melhoria da gestão e do desempenho organizacional integrado em empresas de grande porte, com atuação em segmentos industriais, comerciais e educacionais, tendo desenvolvido visão sistêmica para a gestão e foco estratégico de negócios. Atualmente é especialista em planejamento, processos e modelagem de novos negócios na área de tecnologia e inovação de uma grande federação de indústrias, provendo às áreas de negócio o uso de metodologias capazes de ampliar a eficiência da gestão e alinhamento com as estratégias organizacionais.

Ficha Catalográfica

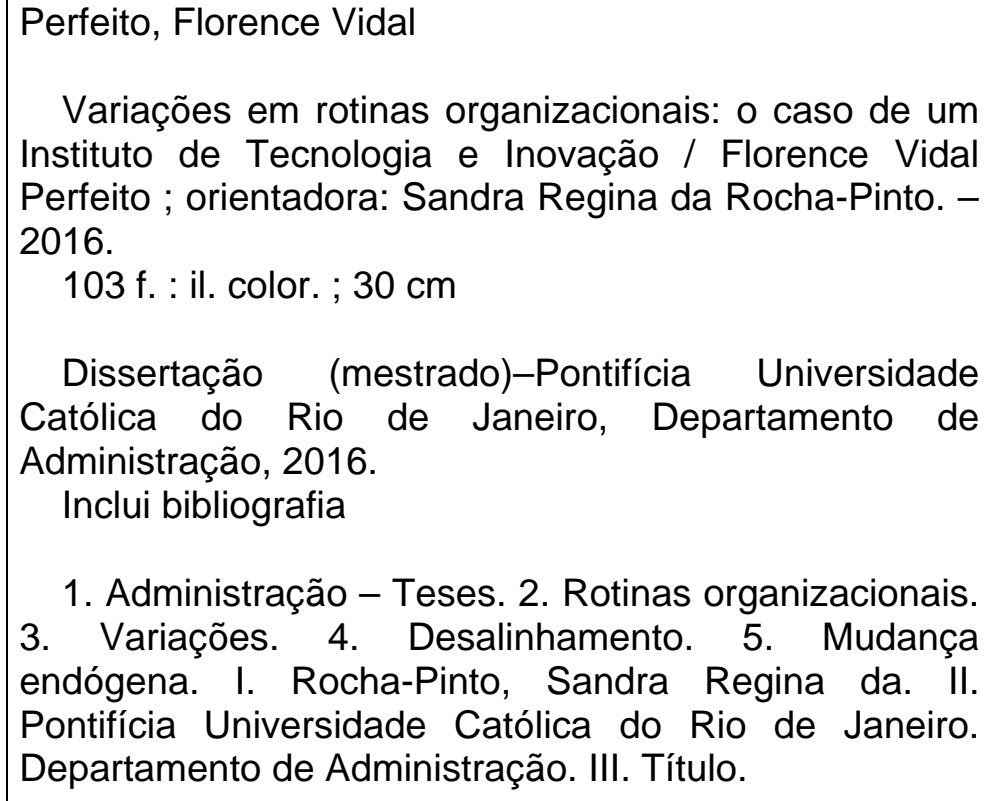
Instituto de Tecnologia e Inovação / Florence Vidal Perfeito ; orientadora: Sandra Regina da Rocha-Pinto. 2016.

103 f. : il. color. ; $30 \mathrm{~cm}$

Dissertação (mestrado)-Pontifícia Universidade Católica do Rio de Janeiro, Departamento de Administração, 2016.

Inclui bibliografia

1. Administração - Teses. 2. Rotinas organizacionais. 3. Variações. 4. Desalinhamento. 5. Mudança endógena. I. Rocha-Pinto, Sandra Regina da. II. Pontifícia Universidade Católica do Rio de Janeiro. Departamento de Administração. III. Título. 
“À minha família, cujo acolhimento emocional de força e apoio, permitiu-me continuar na busca pelo conhecimento..." 


\section{Agradecimentos}

À Professora Sandra Regina que me conduziu bravamente, respeitando o meu tempo e alinhando nossos interesses.

Aos participantes desta pesquisa e a todos os gestores da Organização S, que me acolheram e permitiram, destemidamente, que as investigações acontecessem, demonstrando curiosidade nos resultados práticos para a melhoria dos processos.

Ao grande amigo Paulo e aos demais amigos que estiveram comigo, conduzindo sempre para a escolha dos melhores caminhos. Aos colegas de aula e aos amigos que fiz na PUC, Erick, Bettysa e Carina, cujos laços de amizade perpetuaram.

Ao meu amado companheiro Marcelo, que esteve comigo em todos os momentos, compreensivo e resiliente...amor, sem você nada seria!!

Aos meus pais amados, meu verdadeiro porto seguro, embora distantes, absolutamente sempre presentes. À minha sogra querida, que revisou, incansavelmente, os meus escritos. Ao meu cunhadinho, André, que me incentivou a fazer o mestrado.

Aos meus sobrinhos Vivi, Laurinha e Enrico, espero poder deixar um bom exemplo de dedicação, muito embora seja cedo para vocês avaliarem.

Aos professores membros da banca, Professora Andrea Cherman, Professora Alessandra da Costa e Professor Lincoln Gomes, valeu muito pelas dicas.

A todos os professores do mestrado profissional que contribuíram para o meu aprendizado e evolução. Aos secretários Fabio Etiene e Teresa Campos, por todos os "galhos" quebrados. Todos foram fundamentais.

A Deus, sobretudo, que ofereceu as condições necessárias durante esta jornada em busca pelo saber. 


\section{Resumo}

Perfeito, Florence Vidal; Pinto, Sandra Regina da Rocha. Variações em Rotinas Organizacionais: $O$ Caso de um Instituto de Tecnologia e Inovação. Rio de Janeiro, 2016. 103p. Dissertação de Mestrado Departamento de Administração, Pontifícia Universidade Católica do Rio de Janeiro.

A empresa transforma os seus recursos a partir de rotinas organizacionais, cujas abordagens teóricas têm possibilitado o entendimento do desempenho do negócio, uma vez que elas carregam consigo o poder de transformação. Nesse sentido, esta pesquisa buscou compreender os motivos que justificam as variações nas rotinas organizacionais, dentro do contexto das compras de insumos químicos para um Instituto de Tecnologia e Inovação do Rio de Janeiro. Adotou-se como metodologia o estudo de caso único. A coleta de dados ocorreu entre 24/08/2015 a 29/01/2016 e baseou-se em evidências primárias, com entrevistas de 18 pessoas, por meio de um roteiro semiestruturado, além da análise de mais de 30 documentos e observações empíricas. Os resultados encontrados sugerem falta de integração e desalinhamento de interesses, conceitos e necessidades entre as áreas e atores participantes, incentivando a manutenção de rotinas organizacionais com estruturas e fundamentos inadequados para atender a todos os propósitos da empresa. Estes problemas geraram uma variação prejudicial à produtividade do negócio. Porém, também, permitiram a criação de novos padrões mais adaptados ao contexto e capazes de garantir agilidade para as rotinas de compra, corroborando com a ideia da flexibilidade positiva nas rotinas organizacionais, que provocam a mudança endógena preconizada pela teoria. Desta forma, sugerese ampliar o nível de comprometimento da organização com o negócio a partir da adequação das rotinas organizacionais de compra, incorporando os novos padrões para fomentar a inovação dos processos institucionais, além de oferecer à organização a oportunidade de obter desempenho superior e vantagem competitiva.

\section{Palavras-chave}

Rotinas organizacionais; variações; desalinhamento; mudança endógena. 


\section{Abstract}

Perfeito, Florence Vidal; Pinto, Sandra Regina da Rocha (Advisor). Variations in Organizational Routines: the Case of an Innovation Technology Institute. Rio de Janeiro, 2016. 103p. MSc. Dissertation Departamento de Administração, Pontifícia Universidade Católica do Rio de Janeiro.

The company transforms its resources from organizational routines, whose theoretical approaches have enabled the understanding of business performance, since they carry with them the power of transformation. In this sense, this research sought to understand the reasons for variations in organizational routines, within the context of purchases of chemical inputs for an Institute of Technology and Innovation. The method chosen was the single case study. Data collection took place between 8/24/2015 to 1/29/2016 and was based on primary evidence, with interviews of 18 people, through a semi-structured script, in addition to the analysis of more than 30 documents and artifacts and empirical observations. The results suggest lack of integration and misalignment of interests, needs and concepts between the areas and participating actors, encouraging the maintenance of organizational routines with inadequate structures and foundations to serve all the purposes of the company. These problems have created a variation detrimental to business productivity. However, it also allowed the creation of new standards more adapted to the context and able to guarantee agility for purchasing routines, corroborating with the idea of positive flexibility in the organizational routines that cause endogenous change advocated by the theory. In this way, it is suggested to extend the level of commitment of the Organization to the business from the adequacy of the organizational routines of purchase, incorporating the new standards to encourage innovation of the institutional processes, in addition to providing the organization with the opportunity to obtain superior performance and competitive advantage.

\section{Keywords}

Organizational routines; variations; misalignment; endogenous change. 


\section{Sumário}

1. O problema 13

1.1. Introdução 13

1.2. Objetivos 16

1.3. Delimitação do estudo 16

1.4. Relevância do estudo 17

$\begin{array}{ll}\text { 1.5. Estrutura do Trabalho } & 18\end{array}$

2. Referencial Teórico 20

2.1. Rotinas Organizacionais 20

2.2. Os aspectos da Rotina Organizacional 23

2.3. Relação dinâmica e a Variação das Rotinas Organizacionais 29

2.4. O Papel das Rotinas Organizacionais 33

2.5. Transferência de Conhecimento sobre Rotinas Organizacionais 35

3 . Metodologia da Pesquisa $\quad 39$

3.1. Tipo de pesquisa - fins e meios 39

3.2. Seleção dos sujeitos 40

3.3. Fontes de Evidências 41

3.3.1. Procedimentos e Instrumentos de Coleta de Dados 42

3.4. Trabalho de Campo 43

3.5. Tratamento dos Dados e Procedimentos de Análise 44

3.5.1. Banco de Dados 45

3.6. Limitações do Método 45

4 . Estudo de Caso 47

4.1. A Empresa Objeto de Estudo $\quad 47$

4.2. O Contexto Organizacional 48 
5 . Análise dos Resultados 53

5.1. Alinhamento de papéis, conceitos e interesses 54

5.2. Estruturação das Rotinas Organizacionais 59

5.3. Relação entre os aspectos ostensivo, performativo e artefatos 72

5.4. Transferência de conhecimento sobre a Rotina Organizacional $\quad 77$

5.5. Integração inter e intra áreas e equipes 81

5.6. Variação das rotinas organizacionais, implicações e tratamento 85

6. Considerações Finais $\quad 89$

6.1. Conclusão 89

6.2. Limitações e Pesquisa Futura 93

7. Referências Bibliográficas 95

APÊNDICE A - Lista de artefatos investigados 100

APÊNDICE B - Roteiro da entrevista 101

APÊNDICE C - Variações das rotinas e justificativas 102

ANEXO A - Processo Organizacional de Compras 103 


\section{Lista de figuras}

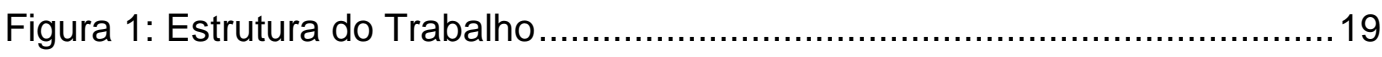

Figura 2: Partes da Rotina Organizacional como sistemas generativos .............2 24

Figura 3: Formação da Rotina Organizacional ..................................................26

Figura 4: Interação entre as performances e os entendimentos ........................28

Figura 5: Formas utilizadas para a coleta de dados ........................................4 41

Figura 6: Triangulação dos dados para a análise............................................4 44

Figura 7: Empresa objeto de estudo.......................................................... 48

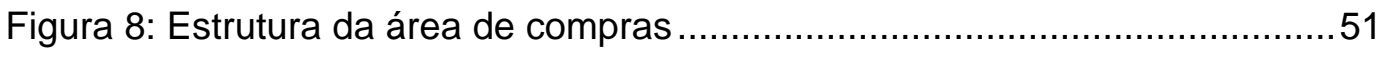

Figura 9: Modelo de Organização dos Processos............................................65 


\section{Lista de quadros}

Quadro 1: Resumo dos Participantes das Entrevistas .....................................40

Quadro 2: Fontes de Evidências e descrição ................................................ 41

Quadro 3: Categorias encontradas com a análise das transcrições ...................53

Quadro 4: Resumo de entendimentos e resultados ........................................59

Quadro 5: Comparação entre as Rotinas Organizacionais ................................70

Quadro 6: Interações e Dinâmica das Relações ................................................. 76

Quadro 7: Variações das rotinas, impactos e tratamento..................................88 


\section{Lista de tabelas}

Tabela 1: Matriz gerada na triangulação dos dados. 


\section{1. \\ O problema}

\section{1. \\ Introdução}

As empresas são formadas por conjuntos de áreas, sistemas, rotinas e processos, as quais precisam funcionar como as peças de um motor, ou seja, cada qual recebendo, processando e provendo "insumos" para o desempenho do seu e dos demais papéis, como uma grande cadeia de valor interna. A Teoria da Administração (in JONES et al., 2011) aponta para a necessidade da eficiência e eficácia organizacional, desde a época de Adam Smith, ainda no Séc. XVIII, com a temática sobre a especialização do cargo e a divisão do trabalho, passando por Taylor (1911), em sua abordagem à Administração Científica, com o estudo das relações entre as pessoas e as tarefas, até mesmo permeando as Teorias Clássicas da Administração, com Weber (1920) e os princípios da burocracia, os quais produziam um sistema formal de organização, além de Fayol (1925), com seus princípios para a eficiência do processo gerencial.

A dinâmica da economia contemporânea exige que as organizações sejam capazes de lidar com mudanças constantes, sempre procurando melhorar as suas estratégias para a busca de vantagens competitivas e sustentabilidade financeira dos negócios. A questão relacionada à perpetuidade nos mercados pode ser explicada mediante a compreensão das características comuns de empresas que alcançaram desempenho superior, focando na compreensão profunda de seus processos organizacionais (MINTZBERG, 2000; WHITTINGTON, 2007).

Um instituto de tecnologia é uma empresa prestadora de serviços, cujo propósito é desenvolver pesquisas de base tecnológica para criar soluções e melhorias aplicáveis aos processos industriais. Para que um instituto de tecnologia em química possa fazer análises e ensaios é imperioso o acesso a três tipos de recursos: pessoas qualificadas, equipamentos adequados e insumos químicos específicos. Para garantir este tripé, áreas organizacionais devem apoiar, formando uma cadeia de valor interna apta a prover o suporte necessário. Portanto, o desalinhamento do papel, da estrutura e das rotinas das 
áreas de suporte às atividades fim implica em obstáculos que impedem a boa prestação do serviço e a eficiência da operação.

Este trabalho pretendeu investigar as rotinas organizacionais que apoiam um instituto de tecnologia e inovação em química na compra de insumos específicos às análises e ensaios. A empresa objeto deste estudo é um instituto do Rio de Janeiro e presta serviços de análises ambientais, toxicologia e higiene ocupacional para as indústrias. Trata-se de um instituto reconhecido como parceiro da indústria na busca pela redução do impacto de suas atividades ao meio ambiente e pela melhoria contínua das condições da saúde do trabalhador, pois o compromisso com questões socioambientais tornou-se, ao longo dos últimos anos, fundamental para a existência das empresas no mercado. Para preservar a identidade e integridade da organização neste trabalho, ele será chamado de "Instituto A".

A decisão pela investigação das rotinas organizacionais de compra de insumos químicos do "Instituto A" foi baseada em três fatos, que apontaram para possíveis problemas. O primeiro fato foi a percepção de que o gestor dos laboratórios estava sendo solicitado por sua equipe técnica, demasiadamente, sobre assuntos ligados à compra de suprimentos. O segundo fato foi uma não conformidade recebida pelo "Instituto A" em uma auditoria de processos, em razão ao descumprimento dos prazos de compra previstos no Acordo de Nível de Serviço (ANS). Por último, um trabalho de mapeamento de problemas realizado junto aos técnicos do "Instituto A", identificou impacto negativo da atividade de compras de insumos no resultado do negócio, uma vez que a área técnica assumiu a responsabilidade direta de realizar a maior parte das compras de insumos necessários à prestação de serviços, mesmo existindo uma área específica para as compras organizacionais, o que consiste em uma variação da rotina organizacional de compras.

Esta pesquisa foi embasada em estudos sobre as rotinas organizacionais que vêm possibilitando a evolução da teoria com base em uma perspectiva prática utilizada por Feldman e Pentland (2003), que definem rotinas organizacionais como padrões repetitivos e reconhecíveis de ações interdependentes realizadas por vários atores. A importância do entendimento da construção da rotina e de sua mudança é legitimada pela consciência do quão essencial é, para qualquer análise, de como o conhecimento organizacional é retido e transferido, para o desenvolvimento da estratégia de negócios e para a criação de políticas de incentivo de práticas empresariais mais eficientes (HODGSON, 2004). As diferentes atividades 
realizadas pelas pessoas dentro do contexto da rotina resultam em experiências únicas, o que qualifica o entendimento da rotina dos participantes como parcial, idiossincrático, e distribuído (FELDMAN e PENTLAND, 2008). Nesse sentido, entende-se a necessidade da visão holística das rotinas de determinada área, as quais permeiam a organização e devem ser investigadas como fenômenos individuais e coletivos.

Portanto, boa parte da base teórica deste trabalho está associada aos achados de Feldman e Pentland, fundamentada na grande quantidade de estudos empíricos desses autores, principalmente nos aspectos performativo, ostensivo e artefatos, bem como na relação entre eles (FELDMAN, 2003). A priorização dessas teorias nesta pesquisa está associada à característica de dualidade da rotina para gerar a estabilidade e flexibilidade, ao poder da agência e à necessidade da investigação das partes da rotina, que vêm permitindo aumentar o entendimento sobre a natureza das rotinas organizacionais, uma vez que o tema requer um olhar aprofundado, já que o complexo mundo real das organizações confronta e impõe aos pesquisadores uma série de desafios aos estudos de campo.

Nesse sentido, considerando que o "Instituto A" é uma unidade de negócio que faz parte de uma organização composta de várias estruturas de apoio, entre elas, uma grande área de compras e suprimentos; considerando a importância dos insumos para a operação do negócio do "Instituto A"; e, considerando a pressão do mercado por redução de custos e aumento dos níveis de serviço, o que legitima a busca pela a eficiência na gestão empresarial, faz-se importante avaliar as rotinas de organizacionais de compra, respondendo-se à seguinte questão: quais fatores motivam as variações nas rotinas de compra de insumos químicos para um instituto de tecnologia e inovação?

Para responder à pergunta de pesquisa, Pentland e Feldman (2005) sugerem a abordagem das rotinas organizacionais a partir da abertura da caixa preta, analisando cada parte da rotina e a relação entre elas, para examinar como o fenômeno das rotinas acontece. O estudo procedeu conforme segue em seis partes, onde a primeira introduz o problema de pesquisa, define os objetivos e delimitação da pesquisa; o segundo apresenta as teorias referenciais utilizadas; o terceiro aborda a metodologia, o quarto a contextualização da pesquisa de campo, o quinto capítulo apresenta a discussão de resultados e, o sexto, as conclusões da pesquisa, limitações e recomendações futuras. 


\section{2.}

\section{Objetivos}

Portanto, este trabalho pretende entender os motivos das variações nas rotinas de compra de insumos químicos de um instituto de tecnologia e inovação. Reitera-se que, embora o foco deste estudo seja nas rotinas de compras, a investigação de problemas organizacionais intrínsecos à área de compras não faz parte do escopo deste trabalho.

Para se atingir o objetivo geral proposto esse estudo prevê, como objetivos intermediários a serem alcançados:

- Investigar se existe alinhamento de interesses e necessidades entre o "Instituto A" e a área de compras, bem como se há alinhamento conceitual sobre a compra de insumos químicos.

- Analisar a estrutura das rotinas de compras por meio do aspecto ostensivo, do aspecto performativo e dos artefatos, constatando se ela traduz o objetivo proposto para a compra de insumos químicos.

- Investigar como é a relação entre os aspectos ostensivo e performativo das rotinas de compra e seus artefatos.

- Verificar se existe transferência de conhecimentos sobre as rotinas de compra de insumos químicos.

- Entender o impacto da variação das rotinas de compra para o negócio.

\section{3.}

\section{Delimitação do estudo}

A "Organização S" é uma empresa privada e sem fins lucrativos, que apoia a indústria fluminense oferecendo, entre outros, serviços de tecnologia e inovação para aumentar sua produtividade, lucratividade e competitividade. O apoio tecnológico à indústria é realizado através de quatro institutos $(A, B, C$ e D), considerados "unidades de negócio". A escolha do "Instituto A" para este estudo de caso se justifica pelas seguintes razões:

- Sofre pressão pela busca contínua da eficiência por ser um dos maiores institutos de tecnologia e inovação do país.

- Precisa garantir o tripé de recursos necessários à prestação de serviços, entre eles, a provisão de insumos químicos.

- Possui laboratórios acreditados pelo INMETRO, que exige qualidade diretamente relacionada ao uso de insumos químicos específicos. 
- Oferece acessibilidade aos dados e informações, além de apoiar o desenvolvimento deste estudo de caso.

A "Organização S" possui várias áreas que apoiam as suas unidades de negócios com a gestão de pessoas, a gestão do planejamento, a gestão financeira contábil, a gestão da comunicação e marketing, a gestão comercial, a gestão de compras e suprimentos, entre outras. Cada uma dessas estruturas possui suas próprias rotinas organizacionais, cujas características transversais são importantes e necessárias ao suporte organizacional. Este estudo de caso pretende focar nas rotinas de compras pelas seguintes razões:

- Em 2015, o "Instituto A" participou de uma avaliação da maturidade da gestão, obtendo uma não conformidade pelo descumprimento da regra de prazo estabelecida para a rotina organizacional de compras.

- A compra de insumos químicos é um dos eixos fundamentais do tripé de recursos necessários à operação do "Instituto A".

- A pressão por eficiência na gestão tem valorizado cada vez mais as atividades relacionadas ao suprimento de materiais, devido ao seu potencial de gerar economias significativas, de reduzir riscos e melhorar os índices de serviço (BAILY et al., 2000).

Por último, esta pesquisa está priorizando a perspectiva teórica das rotinas organizacionais baseada na prática, apoiada nos preceitos dos autores que sugerem a investigação das rotinas a partir do entendimento de suas partes e interações, o que pode ampliar o conhecimento e o entendimento sobre suas variações.

\section{4.}

\section{Relevância do estudo}

Para a empresa, a importância da pesquisa é evidenciada à medida que indica a necessidade de estruturar novas rotinas ou aprimorar as rotinas existentes, estabelecer papéis para a equipe, além de apoiar os processos de gestão, aumentando e eficiência operacional. Além disso, este estudo poderá subsidiar o aumento da Maturidade da Gestão dos Institutos de Tecnologia, uma vez que poderá apontar novos padrões e melhorias necessárias. 
Outrossim, tendo em vista que a "Organização S", que abriga o "Instituto A", faz parte de um conjunto de organizações que apoiam a indústria brasileira, a identificação de melhorias na gestão pode auxiliar outros institutos de tecnologia a reduzir a curva de aprendizagem sobre a gestão da cadeia de suprimentos para a tecnologia, através do uso de boas práticas e lições aprendidas.

Conjuntamente, em um sentido amplo, é relevante para a indústria que a boa gestão do "Instituto A" garanta a prestação de serviços de excelência em química, meio ambiente, saúde e segurança do trabalho, o que contribui para o fortalecimento de programas de apoio, onde inúmeros esforços são aplicados no sentido de levar a inovação tecnológica para aumentar a competitividade empresarial.

A relevância para a teoria é sua aplicação ao contexto organizacional real, a partir da observação das performances in loco, à luz da corrente teórica das rotinas com base na prática, tendo em vista que há poucos estudos neste sentido, justamente pela dificuldade da observação direta promovida pela peculiaridade das observações serem distribuídas no tempo, no espaço e entre vários atores (FELDMAN e PENTLAND, 2008).

\section{5 .}

\section{Estrutura do trabalho}

O presente trabalho está estruturado em seis capítulos ilustrados na Figura 1, que apresenta a organização e estruturação dos tópicos da pesquisa deste estudo de caso. O primeiro capítulo apresenta a introdução ao tema com o problema de pesquisa, os objetivos, a delimitação e a relevância da pesquisa, ou seja, as informações para a compreensão geral do trabalho.

O segundo capítulo aborda o embasamento teórico sobre rotinas organizacionais como o "pano de fundo" essencial deste trabalho.

O terceiro capítulo descreve a metodologia da pesquisa, contendo cada etapa de sua estrutura, bem como os atores participantes e os desafios encontrados.

O quarto capítulo evidencia o estudo de caso propriamente dito, com a análise dos dados coletados à luz da teoria, de acordo com as rotinas existentes na empresa e as interações. Neste momento a análise cruzada dos dados coletados deve prover um diagnóstico sobre a estrutura das rotinas de compra ${ }^{1}$ da empresa.

\footnotetext{
${ }^{1}$ Apenas as rotinas de compra de insumos químicos.
} 
No quinto capítulo serão apresentadas as discussões de resultados do estudo e, por último, o capítulo seis apresentará as conclusões do estudo, as limitações da pesquisa, além de sugestões de agenda de pesquisas futuras que permitam o aprimoramento do trabalho desenvolvido. Ainda nesta etapa, estarão presentes as sugestões e proposições de melhorias para as rotinas organizacionais.

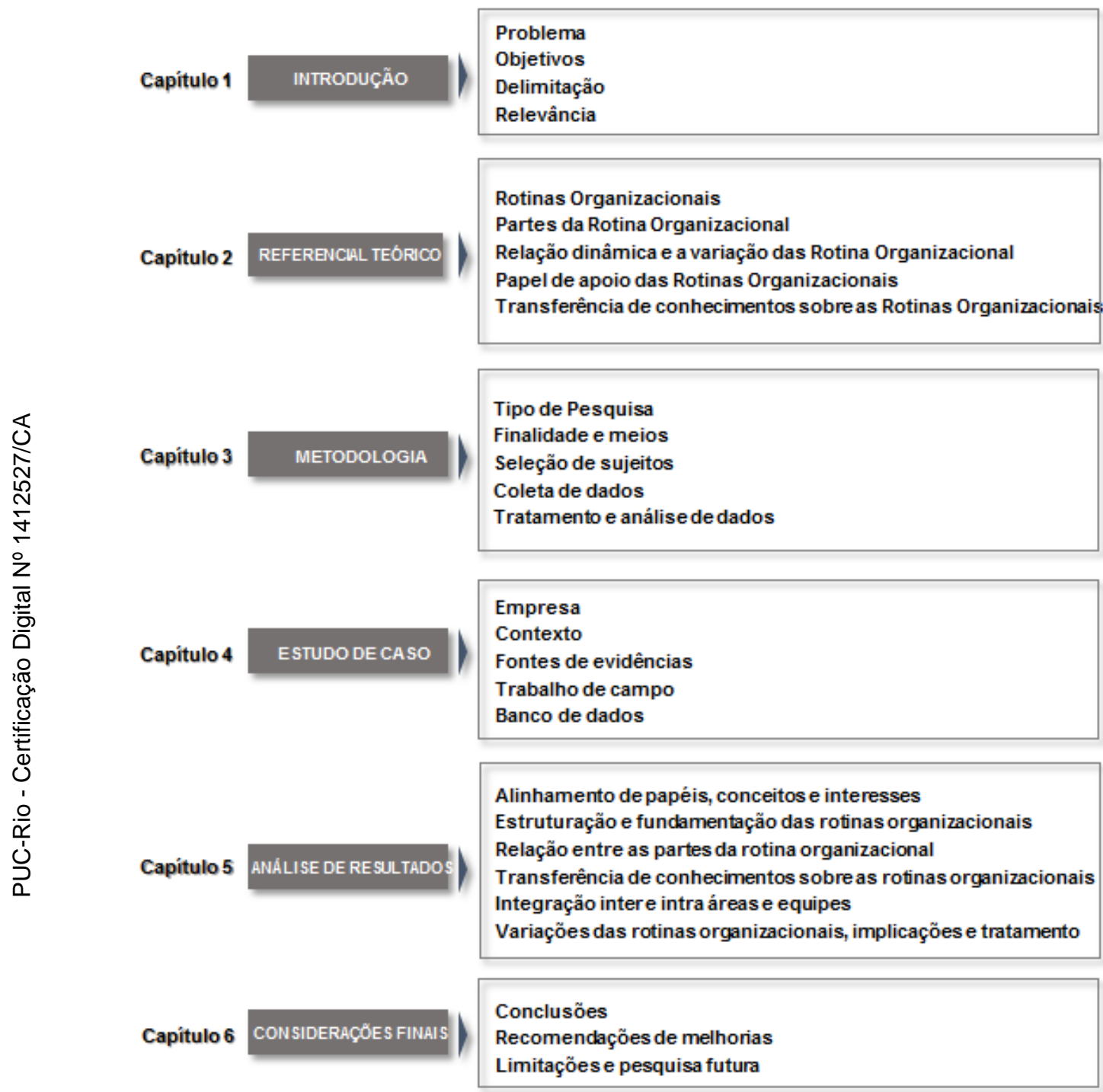

Figura 1: Estrutura do Trabalho

Fonte: Elaborado pela pesquisadora com base em Yin (2003) e Creswell (2010). 


\section{2. \\ Referencial teórico}

\section{1. \\ Rotinas organizacionais}

Uma empresa é formada por vários tipos de recursos que, a partir de rotinas organizacionais, transformam insumos em resultados. Esses recursos podem ser pessoas, dinheiro, ativos físicos, entre outros; os insumos podem assumir desde formas abstratas, como informações e ideias, até as formas mais concretas, como matérias primas diversas. E os resultados consistem em onde a empresa quer chegar e permeiam por objetivos estratégicos com maior ou menor nível de tangibilidade. Segundo Feldman (2004) as rotinas organizacionais são unidades fundamentais para o desempenho de um negócio, uma vez que elas carregam consigo este poder de transformação. Sendo assim, sua gestão se constitui uma função organizacional crítica.

O tema rotinas organizacionais foi abordado pela primeira vez por Stene, em 1940 (apud FELDMAN e PENTLAND, 2003), e vem sido estudado por inúmeros autores que as consideram características comuns a todas as organizações de cunho humano e social, constituindo, inclusive, elementos que podem explicar muitas teorias amplamente aceitas. Desde então, o conceito de rotinas organizacionais vem se aprimorando, tendo iniciado por um conceito tradicional, passado por um conceito evolutivo e tendo alcançado uma teoria baseada na prática.

Seguindo um conceito bastante tradicional, Cyert e March (1963), baseados na Teoria da Firma, conceituam as rotinas organizacionais como regras ou padrões operacionais recorrentes, os quais são explícitos e mudam de acordo com os estímulos recebidos do ambiente. Para esses autores, as rotinas organizacionais evitam a incerteza e garantem comportamentos padronizados que dará estabilidade à empresa, além de conferir certa coordenação e controle. Seguindo, também, uma visão tradicional, Simon (1957) aponta que as rotinas organizacionais permitem a economia do esforço mental, cuja capacidade de decisão e processamento de informações da empresa seguem regras estabelecidas, principalmente, em função da racionalidade limitada dos agentes, da teoria comportamental das empresas e dos vieses na decisão dos indivíduos. 
Sob a ótica evolucionária, Nelson e Winter (1982) contribuíram fortemente para o avanço do estudo sobre as rotinas organizacionais, transpondo a visão restrita ao conceito de procedimentos e programas. Esses autores associaram as rotinas às capacidades organizacionais em um sentido mais amplo, as quais traçam a trajetória da empresa, entendendo a habilidade organizacional como a capacidade de agir de forma coordenada e sequencial, alcançando objetivos de acordo com o contexto. Em seu livro "An Evolutionary Theory of Economic Change" (1982), Nelson e Winter fazem uma analogia entre rotinas e genética, apontando que as rotinas organizacionais estão para a teoria evolutiva econômica, assim como os genes estão para a teoria evolutiva biológica. Desta forma, o comportamento organizacional deixa de ser previsível e regular e passa a ser alternativo e variável, guiado, em parte, por regras já estabelecidas e, em parte, por acontecimentos inesperados, caracterizado pelo sentido darwinista que inspirou os autores a nivelar as rotinas aos genes, lidando bem com o fluxo contínuo e com a diversidade (NELSON e WINTER, 1982).

Por fim, assumindo a perspectiva com base na prática, a teoria de Feldman e Pentland (2003), define rotinas organizacionais como padrões repetitivos e reconhecíveis de ações interdependentes realizadas por vários atores. Os mesmos autores, em 2008, complementam o conceito, referindo-se às rotinas organizacionais como sistemas generativos que podem produzir uma grande variedade de performances, dependendo das circunstâncias sociais e materiais (PENTLAND e H/EREM, 2015; FELDMAN E PENTLAND, 2008). Conjuntamente, Cohen e Bacdayan (1994) reiteram que as rotinas organizacionais são baseadas em conhecimento explícito e tácito (MILLER et al., 2012), construídos por meio das habilidades individuais e podendo definir o desempenho de uma empresa (PENTLAND e FELDMAN, 2005).

A repetitividade se refere aquilo que é contínuo, regular ou igual. Pentland e Hærem (2015) exemplificam esta característica em dois extremos. No primeiro extremo ficam aquelas ações e atividades que podem ser feitas e refeitas inúmeras vezes da mesma forma. Em outro extremo, os autores apontam para a execução de planos ou programas que, ainda que sigam uma orientação definida, jamais terão padrões absolutos, já que são situacionais. 
O padrão reconhecível quer dizer que uma ação é legitimada por características que permitem seu reconhecimento como similar ou que preserva certa semelhança. Quando um padrão não é reconhecido como igual, não é possível afirmar que ele tem sido repetido ou não. Pentland e Hærem (2015) afirmam que as ações padronizadas podem ser distribuídas no tempo e no espaço e, assim, conterem interrupções, exceções, erros, improvisação e mudança ao longo do tempo, implicando em dificuldade no reconhecimento e contagem das ocorrências de uma rotina. Entretanto, Feldman (2000), aponta que alguns padrões da rotina não mudam, ou seja, sua essência é conservada, embora as rotinas possam sofrer algumas variações.

Da mesma forma, se um conjunto de ações não é interdependente, possivelmente não se trata de uma rotina organizacional, mas de ações esporádicas ou singulares. As rotinas são compostas de ações interdependentes, não importando o quanto se repetem ou o quanto são fáceis de serem reconhecidas. Tal interdependência pode estar representada por uma ordem, um fluxo ou uma sequência de ações que seguem um encadeamento lógico (FELDMAN E PENTLAND, 2003).

Por último, as rotinas organizacionais exigem que múltiplos atores estejam envolvidos em sua execução. Cada membro deve ter plena consciência sobre o seu papel ou sobre o papel de cada um no desenvolvimento da rotina, muito embora as pesquisas recentes incorporem a possibilidade de atores não humanos, como sistemas computadorizados ou robôs para a realização de partes de uma rotina (FELDMAN e PENTLAND, 2005). Aquelas atividades, tarefas ou hábitos individuais, ainda que fundamentais para a empresa, não fazem parte do conceito de rotinas organizacionais. Entretanto, Lazaric (2011) reitera que cada padrão de ação recorrente da organização pode esconder uma rotina, embora, também mencione que nem todas as interações constituem rotinas, devendo-se evitar rotulagem imprecisa.

Considerando as rotinas organizacionais como práticas sociais, a materialidade e a agência vem sendo objeto de estudo em várias pesquisas do campo das organizações e tecnologia. O interesse por esses tópicos se justifica pelas rotinas serem formadas a partir de estruturas materiais e ideológicas que influenciam padrões de ação que os participantes criam e recriam (PENTLAND e FELDMAN, 2008). Os mesmos autores reforçam a utilização da rede de 
narrativas ${ }^{2}$ como mecanismo de pesquisa, porque permite expressar os padrões reais e possíveis da ação que pode ser gerada pela rotina quando a tecnologia faz parte do processo (PENTLAND e FELDMAN, 2007). A inseparabilidade da agência social e material traz à tona a sociomaterialidade defendida por Leonardi et al. (2012) e, ainda que cada parte mantenha sua forma distinta, dependem uma da outra para a produção e perpetuação das práticas, a partir de tecnologias que trazem mudanças organizacionais profundas na forma de agir, organizar e comunicar.

A visão com base na teoria prática, principalmente a partir dos teóricos que focam no poder da agência e apontam a necessidade da investigação das partes da rotina, foi priorizada nesta pesquisa. Algumas categorias foram introduzidas, segundo D'Adderio (2008), a fim de identificar e analisar os mecanismos internos da rotina, enfatizando-a como um sistema sofisticado e caracterizado por sua estrutura interna e dinâmica, que vem motivando os teóricos a entender um pouco mais. Feldman (2004) reitera que a estrutura interna da rotina é capaz de prover informações imprescindíveis que aumentarão o conhecimento sobre a Teoria de Rotinas Organizacionais, muito embora, posteriormente, a mesma autora aponte a complexidade da rotina organizacional como um fenômeno que requer cuidado metodológico ao utilizá-la como unidade de análise (FELDMAN E PENTLAND, 2008; HANNANA e FREEMAN, 1983).

\section{2.}

\section{Os aspectos da rotina organizacional}

Pentland e Feldman (2005) apontam três formas diferentes para a abordagem das rotinas organizacionais como unidades de análise. A primeira delas é a visão da rotina como uma "caixa preta", considerada a forma mais utilizada pelos pesquisadores, onde apenas os inputs e outputs são analisados, sem considerar o processamento; a segunda forma de abordagem é mediante a análise das partes da rotina organizacional, considerando seus aspectos ostensivo, performativo e artefatos; por último, os autores apontam a análise das interações entre as partes da rotina. Cada abordagem conduz a um determinado resultado e a opção por uma delas depende da pretensão da abordagem e nível

\footnotetext{
${ }^{2}$ A rede narrativa é o método que representa e visualiza padrões de ação, retendo possibilidades e alternativas. Para a representação explícita de uma rotina organizacional como um padrão de ação é necessário ouvir cada evento funcional em cada performance, pois cada um fornecerá uma ocasião para a variação (PENTLAND e FELDMAN, 2007).
} 
de profundidade sobre um comportamento organizacional (FELDMAN e PENTLAND, 2008).

Com o objetivo de propor um melhor entendimento sobre o conceito das rotinas organizacionais, Feldman e Pentland (2003) desmembram as rotinas em partes, utilizando a abordagem sugerida por Latour (1986), cuja aplicação original foi no campo da Sociologia. Dessa forma, os autores consideraram que a rotina possui um aspecto "ostensivo", ou seja, o conhecimento abstrato de tudo aquilo que permite aos seus participantes a orientação e explicação sobre como uma rotina deve ser realizada; por outro lado, a rotina possui um aspecto "performativo" o qual está ligado à sua realização, uma vez que ela será performada por pessoas específicas, em horários específicos, em locais específicos. Sem estes dois aspectos, a rotina não pode existir.

Feldman e Pentland (2003) ressaltam, ainda, que os aspectos da rotina organizacional podem ser ativados por artefatos, que contribuem bastante para a pesquisa sobre o tema, pois apoiam a construção da base de dados e servem como identificadores dos aspectos ostensivo e performativo da rotina. A Figura 2 ilustra as partes das rotinas organizacionais desenvolvida por Feldman e Pentland (2008), evidenciando o arcabouço de recursos que constitui um sistema generativo capaz de produzir uma variedade de ações.

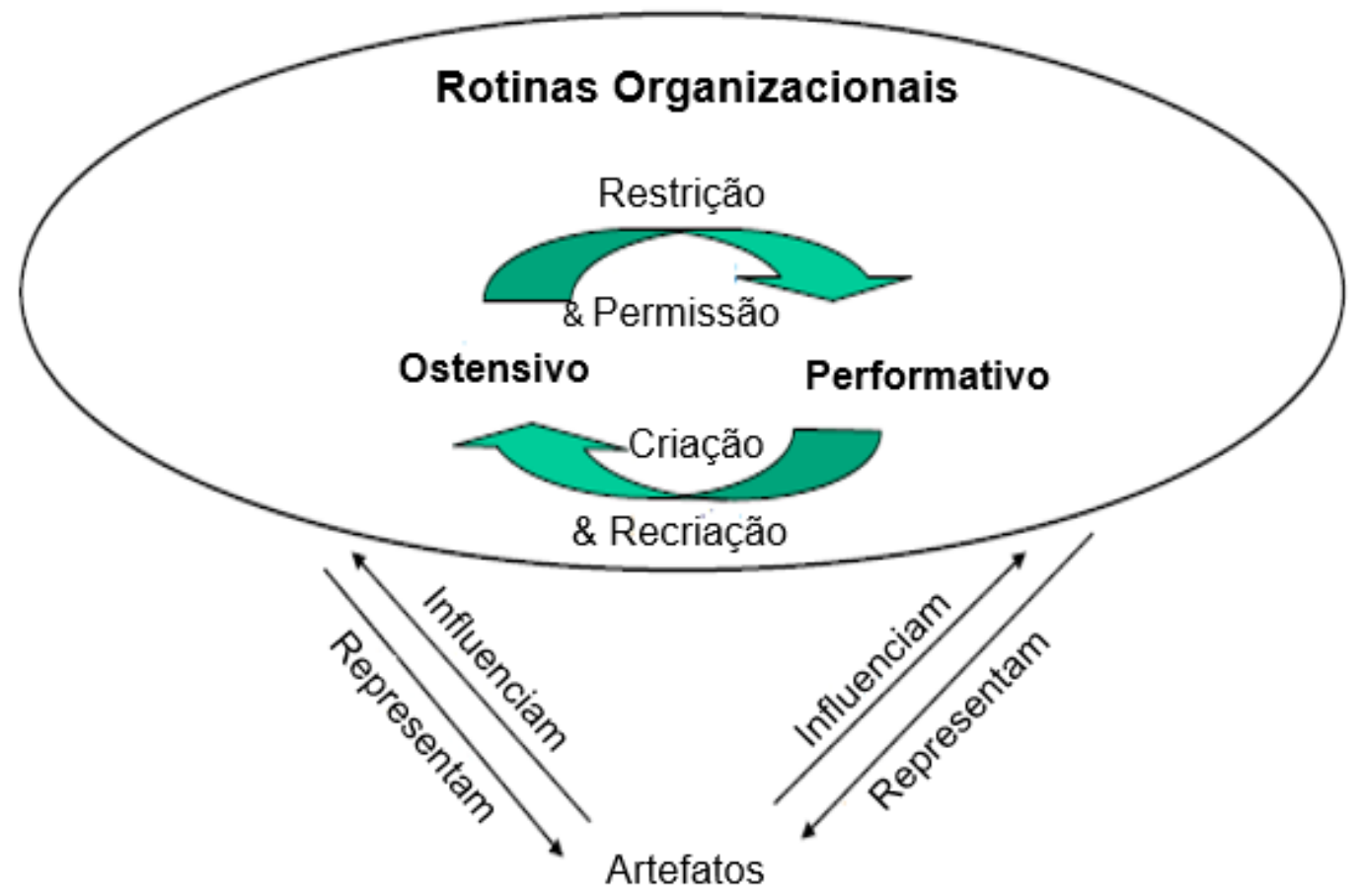

Figura 2: Partes da Rotina Organizacional como sistemas generativos Fonte: Pentland e Feldman (2008), p. 241. 
A dualidade de estrutura e ação promovida pelo sistema generativo da rotina, onde os padrões estabelecidos representam sua estrutura e o ato de realizá-la representa a sua ação, promove a estabilidade e o dinamismo simultâneos (FELDMAN E PENTLAND, 2005). A relação entre suas partes torna a rotina uma fonte de mudança, já que ela pode ser executada de forma diferente, de acordo com as pessoas, os locais e os tempos, mesmo que tenham estruturas ostensivas padronizadas.

\section{O Aspecto Ostensivo}

O aspecto ostensivo da rotina se refere aos padrões usados para guiar os participantes nas performances específicas, como se fosse um script (PENTLAND E FELDMAN, 2005). Ele representa a narrativa da rotina pelos participantes e não pode ser observado como o aspecto performativo. Além disso, as narrativas podem não ser coerentes ou consensuais, já que não são visíveis (FELDMAN e PENTLAND, 2008), pois diferentes pessoas podem ter entendimentos diferentes sobre uma mesma tarefa, que está correta sob o ponto de vista do seu papel, mas pode gerar conflitos de ideias sobre como uma rotina deve ser performada. Portanto, o aspecto ostensivo é muito dependente do contexto, seu entendimento pode variar de acordo com a pessoa e o evento, podendo ser formado por meio de suposições tácitas que devem fazer sentido, ou mesmo um conjunto de sobreposições e relatos parciais (FELDMAN E PENTLAND, 2008). Segundo esses autores, o grande desafio do aspecto ostensivo é encontrar o "fio da meada", a conexão da narrativa que permite identificar o fluxo das ações e atividades coerentes como parte de uma rotina.

A Teoria da Identificação (WHITE, 1992 apud FELDMAN e PENTLAND, 2008) preconiza a necessidade do pesquisador identificar as fronteiras da rotina a fim de reduzir a ambiguidade e a variação. A Teoria da Comparação (RAGIN, 1987 apud FELDMAN e PENTLAND, 2008) sugere que, após a identificação de uma rotina, deve ser possível compará-la. Entretanto, a dificuldade na identificação e comparação do aspecto ostensivo da rotina é justificada pelos múltiplos participantes, cada um com o seu ponto de vista confundindo a noção de sequência de ações. Esta complexidade de análise vem forçando os pesquisadores a realizar confrontos de dificuldades e desenvolver novos conceitos que permitam a abertura da "caixa preta" do fenômeno rotina organizacional (FELDMAN e PENTLAND, 2008). 
Paralelamente, Feldman e Pentland (2008) consideram que a armadilha do aspecto ostensivo está na simples tendência das pessoas fazerem confusão sobre o conceito da rotina. Contudo, as conexões entre pessoas que trabalham juntas ajudam no entendimento sobre o que é necessário fazer em um momento específico da performance e com qual objetivo realizar a rotina (FELDMAN e RAFAELI, 2002). Para essas autoras, esses dois entendimentos podem traduzir a forma como a empresa busca se adaptar às circunstâncias, podendo ser relevantes para a compreensão do resultado da rotina organizacional.

Sobretudo, ainda que os indivíduos percebam a familiaridade em relação à realização de uma rotina, não têm essa mesma facilidade para explicá-la verbalmente. Devido a esse fato é possível verificar a ação clara de um componente tácito que está implícito na rotina e que depende do ponto de vista do participante (MILLER et al., 2012; COHEN e BACDAYAN, 1994). Corroborando a observação sobre o elemento tácito, também, a pesquisa de Cohen e Bacdayan (1994), abordou a memória de procedimento, onde os indivíduos demonstram saber executar a tarefa usando, inclusive, com conhecimento tácito, ainda que não haja a consciência dele. Mais tarde, Miller et al. (2012), estudaram a dinâmica recíproca entre a ação e a memória das rotinas, evidenciando três tipos distintos de memória que permitem a criação das rotinas: a memória de procedimento (saber o que deve ser feito); a memória declarativa (conhecimento sequencial sobre o que deve ser feito); e a memória transacional (busca de ajuda em outras pessoas para apoiar na tarefa). Esses três tipos de memórias são essenciais para o aspecto ostensivo da rotina organizacional e estão ilustrados na Figura 3, com a representação da interação entre as performances individuais da rotina e seu entendimento ostensivo (FELDMAN AND PENTLAND, 2003).

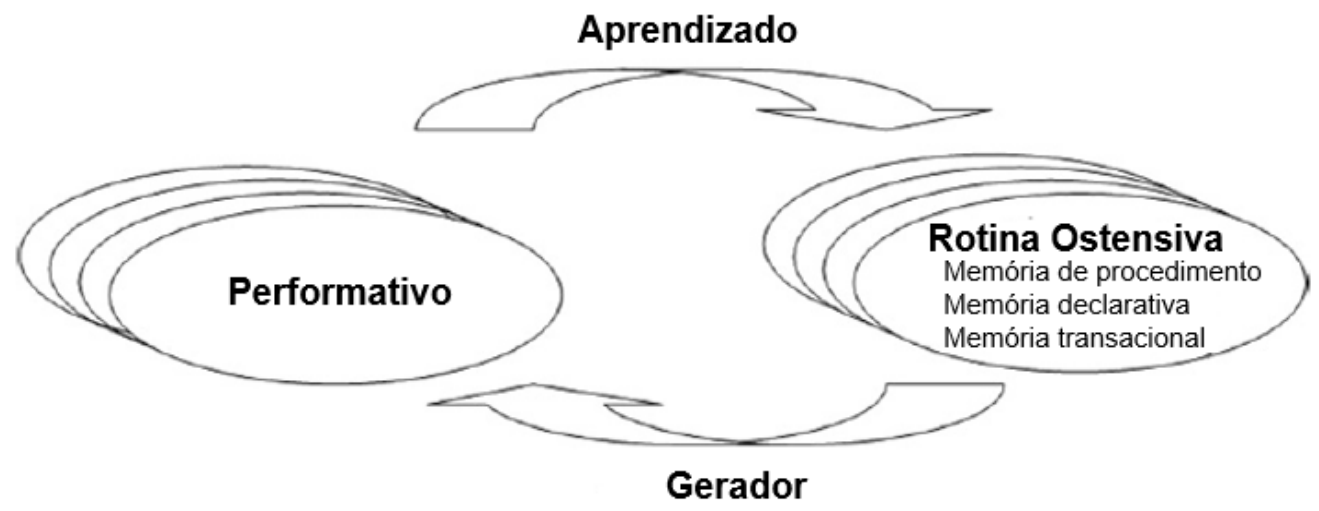

Figura 3: Formação da Rotina Organizacional Fonte: Miller et al. (2012) 


\section{Os Artefatos}

Os artefatos são usados para tentar garantir a reprodução de padrões de ação particulares (PENTLAND e FELDMAN, 2008). Muito embora eles apoiem os aspectos ostensivo e performativo da rotina, esses autores apontam a tendência da confusão dos artefatos com o aspecto ostensivo e dizem seguir a compreensão adotada por Weber (1968) de que cada artefato deve estar de acordo com sua intenção de produzir e usar. Por exemplo, a descrição do fluxo da rotina compras é um artefato que reflete seu aspecto ostensivo; já um histórico de transações com fornecedores é um artefato que reflete o aspecto performativo. Sendo assim, os artefatos devem ser tratados como indicadores subjacentes dos aspectos ostensivo e performativo. Entretanto, os artefatos podem não apontar os procedimentos necessários para o desempenho de uma rotina. Podem estar incompletos, desatualizados, ambíguos ou mesmo não apontarem a lógica correta que guia a ação (FELDMAN E PENTLAND, 2008). Além disso, a existência de artefatos não garante a existência de uma rotina organizacional (PENTLAND e H/EREM, 2015; PENTLAND e FELDMAN, 2005).

Pentland e Feldman (2008) argumentam que, ao menos em parte, a criação de artefatos cuja intenção é proporcionar padrões de ação acabam causando uma desconexão entre metas e resultados. Segundo os autores grande parte das rotinas são tentativas da organização em projetar as práticas de trabalho eficientes e eficazes, em vez de entender que esse é um processo que acontece naturalmente. As equipes que desenham e redesenham as rotinas acabam produzindo um arcabouço de instrumentos diversos, como formulários, listas de verificação, procedimentos e softwares, esperando obter um resultado que nem sempre virá, pois, o artefato limita-se às interações entre o indivíduo e o próprio artefato, desconsiderando a característica generativa da rotina organizacional, que deve coordenar as ações de múltiplos atores (PENTLAND e H/EREM, 2015; FELDMAN e PENTLAND, 2008). Os artefatos são importantes como instrumentos capazes de prover uma padronização de ações individuais, porém, não garantem a coordenação da performance das ações coletivas dos atores (PENTLAND, e FELDMAN, 2008).

A ontologia sobre o material (artefatos) versus o social (ações coletivas) traz implicações práticas para quem quer criar mudança nas rotinas organizacionais. Artefatos criados para rotinas que exigem padrões de ação rígidos podem funcionar melhor, pois as regras serão seguidas (COHEN, 2007). $\mathrm{O}$ autor argumenta que mesmo na atualidade as rotinas organizacionais são interpretadas como padrões estúpidos ou rígidos e faz um trocadilho entre 
"rotinas vivas" e "rotinas mortas", referindo-se às rotinas mortas como os artefatos rígidos, sem sentido e que podem ser explicitamente arquivados ou armazenados. O autor aponta o exemplo de um artefato qualquer, uma Ficha de Especificação de Material, por exemplo, que é desenvolvida por pessoas diferentes das que criaram a rotina e é inútil na maior parte das vezes por aqueles que a desempenham. Por outro lado, as "rotinas vivas" são aquelas que envolvem as pessoas e que são capazes de aprender com a experiência.

\section{O Aspecto Performativo}

A performance está relacionada com ações específicas realizadas por pessoas específicas, em um tempo específico dentro da rotina organizacional (PENTLAND E FELDMAN, 2005). Em geral, estão distribuídas no tempo e no espaço, podendo ser difíceis de serem observadas, pois algumas ações podem estar totalmente visíveis e outras menos evidentes (FELDMAN E PENTLAND, 2008). A qualidade de um serviço pode ser alterada ou variar de acordo com sua performance, ainda que tenha havido um acordo inicial entre as partes interessadas.

Feldman (2003) apresenta uma proposta que fundamenta como as performances de uma determinada rotina influenciam as performances futuras desta mesma rotina, a partir de performances relevantes, com a repetição dos entendimentos sobre como a organização opera e performa uma rotina particular, conforme ilustrado na Figura 4. As performances criam e recriam os entendimentos enquanto os entendimentos restringem e permitem as performances (FELDMAN, 2003).

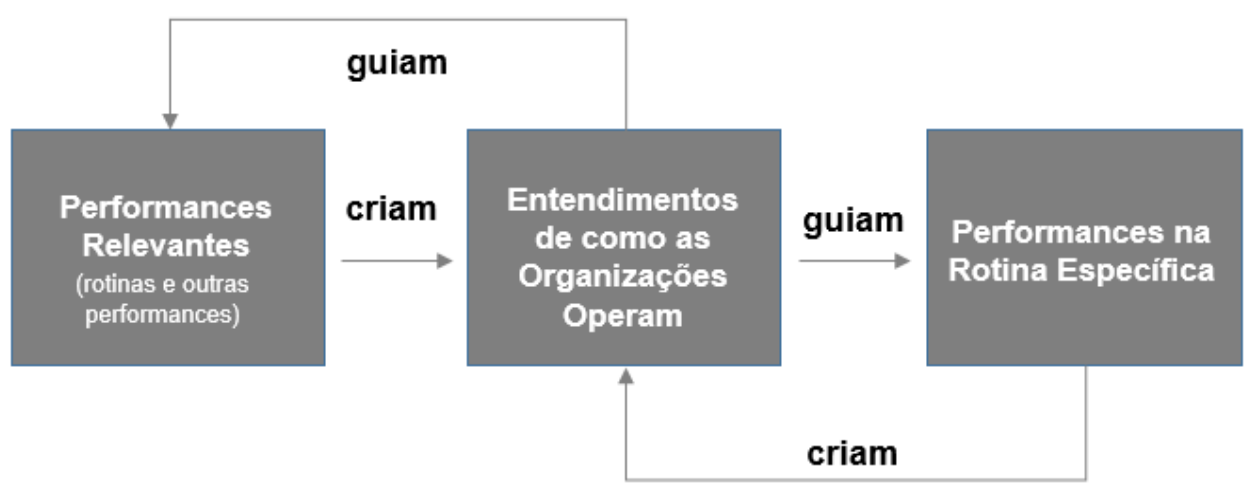

Figura 4: Interação entre as performances e os entendimentos Fonte: Feldman (2003) 
O aspecto performativo permite a criação, atualização e manutenção dos artefatos a partir das ações performadas pelos sujeitos, que envolvem, inevitavelmente, uma série de comportamentos, pensamentos e sentimentos (FELDMAN, 2000). Os mecanismos para guiar, referir e explicar ajudam a produzir uma variação legítima da performance que cria, mantém e modifica a ideia da rotina. No momento de performar uma rotina é possível usar mecanismos que a deixam igual às demais, gerando estabilidade; ou usar mecanismos que façam com que a performance fique diferente, gerando mudança.

O ponto de vista da performance da rotina é crítico durante as observações dos pesquisadores, pois, a performance pode ter um significado diferente, além de só poder ser observada em períodos curtos de tempo. Nesse sentido, Feldman e Pentland (2008), apontam que muitos pesquisadores adotam esquemas e codificações para representar as observações. A maioria dos estudos sobre a performance das rotinas comparam performances em circunstâncias específicas de mudança e outros criam experimentos e simulações que não poderiam acontecer em ambiente organizacional real (PENTLAND e FELDMAN, 2005).

\section{3. \\ Relação dinâmica e a variação das rotinas organizacionais}

Com a intenção de explicar como as empresas ficam estáveis, mudam ou sobrevivem nos mercados, Feldman e Pentland (2003) desafiaram a compreensão tradicional de rotinas organizacionais como criadoras de inércia na empresa (CYERT e MARCH, 1963; SIMON, 1957), direcionando-as para importantes meios capazes, também, de gerar flexibilidade e mudança. Entender a relação dinâmica da rotina é fundamental para a sua gestão, alteração ou manutenção (FELDMAN e PENTLAND, 2003). Porém, conforme mencionado por D'Adderio (2008), a complexidade apresentada por este tema indica que ainda há muito que explorar sobre a Teoria da Rotina, muito embora tenha havido avanços teóricos neste sentido nos últimos anos. Essa lacuna de completude sobre a compreensão teórica da rotina, na presença de mudanças endógenas e exógenas também foi apontado por Safavi (2013). 
A obra de Pentland e Feldman (2005) aponta três formas de entender as relações entre as partes das rotinas organizacionais, a partir de interações entre os aspectos ostensivos e performativos; entre os aspectos ostensivos e os artefatos e entre as performances e os artefatos. Apesar de haver muitas formas de analisar essas relações, esses autores focaram nas divergências entre as três partes, argumentando que as rotinas organizacionais são o resultado de suas performances e de seu entendimento, valorizando o papel da agência destacado por Emirbayers e Mische (1998), como ingrediente que origina a capacidade endógena de promover a mudança.

Ainda que os aspectos ostensivos e performativo tenham características de repetitividade e de se constituírem mutuamente, segundo Pentland e Feldman (2005) eles sofrem variações, principalmente na performance, já que é muito difícil repetir um padrão. O aspecto ostensivo varia uma vez que pode considerar ações necessárias e apropriadas de acordo com a situação, além de que cada participante terá uma visão sobre ele e fará uma narrativa diferente. Quanto maior a diversidade entre esses dois aspectos, maior será a variação, ou seja, a falta de consenso ou ambiguidade no aspecto ostensivo implica em variação no aspecto performativo. Por outro lado, o aspecto ostensivo pode se tornar uma meta a ser atingida, requerendo o esforço dos participantes em mantê-la estável. Porém, o aspecto performativo poderá variar no sentido de combinar formas melhores de atingir o aspecto ostensivo. As variações no aspecto performativo trazem novas visões para os participantes, expandindo a capacidade das rotinas (PENTLAND e FELDMAN, 2005). Segundo Feldman (2000) a dinâmica da relação entre os dois aspectos provoca a mudança endógena contínua na rotina organizacional, podendo afetar a eficiência e a produtividade da empresa de forma positiva e negativa, revitalizando ou paralisando as atividades.

A pesquisa de D'Adderio (2011) buscou melhorar a compreensão da influência dos artefatos na dinâmica das rotinas. Segundo Pentland e Feldman (2005), a habilidade da observação de performances pode influenciar a divergência entre os artefatos e as performances. As situações em que as performances sejam difíceis de monitorar ou observar suscitam a novas performances como improvisações ou uso de atalhos. Nesse caso, os artefatos permanecem estáveis, pois as regras e normas não mudaram, porém, a prática mudou significativamente. Outra condição de divergência é o nível de especificidade do artefato. Algumas condições dificultam seu detalhamento, tornando impossível especificar os comportamentos particulares dos 
participantes. Com regras vagas, a performance fica mais predisposta às variações. Rafaeli e Pratt (2006) defendem os "artefatos ligados", como procedimentos escritos e performances, que mantêm uma relação especial mútua, evoluindo uns dos outros ou feitos para replicar o outro.

Entretanto, para Pentland e Feldman (2005), o relacionamento entre os artefatos e as performances encobrem as relações de poder dentro das organizações, por meio do controle de comportamentos. Se existem regras, é porque elas devem ser cumpridas e sua adoção é uma medida de controle. Alguns mecanismos e técnicas são utilizados para conter as divergências nos contextos onde o comando hierárquico quer garantir que as ações sejam realizadas. Nos contextos onde há maior empoderamento dos participantes, os gestores entendem e legitimam o trabalho dentro das pequenas variações. Porém, grandes variações em um contexto de muito controle apontam para resistência aos artefatos ou desentendimentos em relação ao trabalho a ser desempenhado. A variação entre os artefatos e as performances em ambientes de grande controle pode indicar a desatualização ou a desatenção na criação do artefato (PENTLAND e FELDMAN, 2005).

D'Adderio (2008) cita duas correntes teóricas ao considerar a influência das regras formais sobre as performances. A primeira aponta a visão dos artefatos indicando um "enquadramento" para as ações, com poder para definilas e prescrevê-las. A segunda segue uma lógica de "transbordamento" das ações, com agentes humanos capazes de interpretar, modificar e, em alguns casos, substituir totalmente uma regra ou procedimento.

Feldman (2000) aponta que, frequentemente, os artefatos assumem o papel das rotinas, sua ideia e entendimento, sendo confundidos com o aspecto ostensivo. O artefato precisa expressar o entendimento consensual sobre a rotina e sua intenção, muito embora, às vezes não haja este entendimento. Pentland e Feldman (2005) afirmam que o relacionamento entre artefatos e aspecto ostensivo está ligado ao alinhamento de documentos e regras para o entendimento do que deve ser realizado e as divergências entre eles indicam desalinhamento entre o trabalho e a gestão, podendo expressar a divergência entre metas e necessidade de grupos e áreas diferentes ou entre o relacionamento entre a empresa e públicos relevantes. 
Além dos artefatos originados no ostensivo como regras, normas e formulários, os artefatos oriundos das performances como os registros sobre interações, as ligações, os e-mails e todo o networking dos profissionais suscitam possibilidade de relacionamentos que potencializam os artefatos como objetos das rotinas. Portanto, diferentes tipos de artefatos revelam as diferentes relações entre esses artefatos e o aspecto ostensivo da rotina organizacional (PENTLAND e FELDMAN, 2005).

O conceito das rotinas como fonte de estabilidade e controle e, ao mesmo tempo, como fontes de mudança endógena nas organizações tem alterado a compreensão sobre as mudanças nas empresas (GEIGER e SCHRÖDER, 2014). Nesse contexto, é comum que os participantes das rotinas frequentemente sofram as pressões por equilíbrio para manter a consistência nas rotinas, ainda que haja a mudança nos padrões (TURNER e RINOVA, 2012).

Em geral, crises ou circunstâncias exógenas podem desencadear mudanças nas rotinas. Porém, Feldman (2000) aponta para mudanças em ambientes estáveis. A teoria sobre a dualidade da rotina foi apoiada pelo construto do dinamismo das rotinas organizacionais da Teoria da Estruturação de Giddens (1984), uma vez que preconiza que os atores, a partir do seu conhecimento, monitoram o ambiente social e sua ação, assim como a de outros atores e essa competência do agente humano, possibilita a mudança da prática da rotina organizacional. Portanto, este autor também afirma que as rotinas não são simplesmente repetitivas ou inconscientes, mas podem ser conscientes ou reflexivas (GIDDENS, 1984; PENTLAND e HÆREM, 2015). Para Feldman e Pentland (2003), a relação entre os dois aspectos da rotina cria oportunidade para a variação, seleção e retenção de novas práticas e padrões de ação, possibilitando inúmeros resultados, reiterando que o potencial da rotina como um mecanismo de mudança só pode ser entendido mediante a interação entre os dois aspectos (FELDMAN e PENTLAND, 2003).

Alguns elementos situacionais, como os participantes das rotinas, podem favorecer a variação de performances, principalmente porque os indivíduos e grupos têm diferentes interações com as rotinas organizacionais, seguindo intenções e orientações particulares, sugerindo que o papel da agência pode moldar a performance das rotinas (HOWARD-GRENVILLE, 2005). A mesma autora aborda a questão do contexto organizacional, que não impede a flexibilização da rotina, mas pode restringir sua adaptação. Feldman e Pentland (2003), também trazem a agência para o centro das discussões, explorando a 
questão do poder e da subjetividade na performance da rotina, apontando que o desempenho exige a adaptação aos contextos, com mudanças em curso para manter o sentido das ações para realidades futuras. Nesse sentido as rotinas requerem uma autorreflexão dos participantes e o resultado é a mudança endógena da rotina organizacional. A agência sugere a performance das rotinas como um fluxo que inclui as ações que as pessoas experimentam no trabalho.

Portanto, entende-se como fundamental a argumentação de Feldman e Pentland (2003), que apontam as práticas das rotinas como inerentemente práticas de improvisação, realizadas num contexto de regras e expectativas, cujos participantes sempre escolhem novas formas de performar. Rerup e Feldman (2011) exploram o papel da aprendizagem por tentativa e erro como uma forma de mudança nas rotinas organizacionais a partir de novas interações. Assim, a mudança endógena nas rotinas é possível em função da agência, pois as pessoas combinam elementos passados ou ações de outras fontes de informação para lidar com situações presentes, afetando o entendimento original sobre a rotina. Feldman (2000), também, aponta as crises ou aspectos exógenos como causadores de variações.

\section{4. \\ O papel das rotinas organizacionais}

As rotinas formam a estrutura para as ações da empresa, exercendo o papel de coordenação, apresentando sequência e uniformidade (DOSI; NELSON; WINTER, 2000), auxiliando o gerenciamento da empresa e trazendo coerência às suas ações (NELSON; WINTER, 1982). De acordo com esse papel de coordenação, há uma expectativa sobre os comportamentos a serem desempenhados, sugerindo referências para os indivíduos que as executam (SIMON, 1997) e formando um conjunto de ações que podem ser acompanhadas e controladas pelas empresas. Portanto, sem rotinas, as organizações perdem em eficiência estrutural que guiam as atividades de seus colaboradores (COHEN; BACDAYAN, 1994).

Por um lado, as rotinas apoiam o desenvolvimento da empresa, ajudando a pavimentar o caminho para o sucesso, como elementos fundamentais para a coordenação de processos, aperfeiçoamento contínuo, armazenamento e transferência de conhecimentos (GOUSSEVSKAIA et al., 2005). Por outro lado, alguns autores contrapõem que, embora sejam reconhecidas como um aspecto essencial do trabalho organizado, também podem ser uma fonte de inércia, de inflexibilidade e de ausência de raciocínio para quem as executa (HANNANA e 
FREEMAN, 1983; WEISS e ILGEN, 1986; GERSICK e HACKMAN, 1990; e ASHFORTH e FRIED, 1988). Porém, é possível admitir que as rotinas organizacionais reunem recursos importantes para a empresa prestar suas contas e estabelecer suas políticas de segurança.

As rotinas possuem, também, o papel de gatilhos, podendo ser acionadas e acionar outras rotinas. Nelson e Winter (1982) apontam que "certas maneiras de se fazer as coisas" podem levar a resultados consistentemente satisfatórios. Porém, quando houver o estabelecimento de padrões fixos, e a situação requeira algum tipo de customização ou personalização, pode haver inadequação do uso da rotina como gatilho, o qual desencadeará rotinas inapropriadas para a situação.

Outro papel comum das rotinas é na minimização dos conflitos. Os atores agem de acordo com seus interesses e suas ações são norteadas por seus valores, habilidades, hábitos e reflexos. Como esses atores precisam interagir no ambiente corporativo, as diferenças de personalidade se constituem em um grande potencial de conflitos. Contudo, as rotinas organizacionais acabam criando referenciais para as ações dos indivíduos, minimizando este potencial. Para Nelson e Winter (1982) as rotinas propiciam trégua, atuando no sentido de mediar disputas e conflitos organizacionais.

A redução da incerteza, também, é um papel das rotinas organizacionais. No contexto da incerteza, as pessoas se adaptam e imitam comportamentos para buscar o sucesso, com base na tentativa e erro, podendo criar rotinas para resolver problemas (FELDMAN, 2003; RERUP e FELDMAN, 2011).

Para ser competitiva no mercado, uma empresa precisa promover a inovação em seus processos a fim de garantir a satisfação de seus clientes, ofertando melhores serviços e produtos. Nesse sentido, as rotinas exercem papel fundamental para a inovação, a qual consiste no resultado do aprendizado quando vários agentes se unem e utilizam seus conhecimentos, de maneira complementar, para construírem algo novo. Inclusive, através delas, é possível entender como ocorre o processo de inovação nas empresas, uma vez que concretizam grande parte do trabalho realizado e, ainda, a partir de seu conceito, é possível entender as diferenças de comportamento e performances das empresas (GUENNIF; MANGOLTE, 2002). 
Portanto, a partir de suas rotinas uma empresa pode acumular estocar, aplicar, alterar e transmitir conhecimento, servindo como memória da empresa (NELSON; WINTER, 1982; DOSI; LEVITT; MARCH, 1988). Sendo assim, as rotinas possuem o papel de incorporar e transmitir o conhecimento organizacional. Além disso, já que representam um repositório do conhecimento acumulado pela empresa, possibilitam que a execução do padrão seja de forma rápida e automática, permitindo a economia de recursos cognitivos para outras atividades em que o esforço mental seja indispensável (BECKER, 2004). E, muito embora as rotinas construídas a partir de sistemas emergentes sejam mais efetivas para beneficiar a organização e gerar interações entre os participantes, elas possuem uma importância estratégica menor, visualizadas isoladamente (WITT, 2011).

\section{5 .}

\section{Transferência de conhecimento sobre rotinas organizacionais}

Correntes estratégicas baseadas em recursos consideram as capacidades, competências e conhecimento como formas de ativos chaves para a empresa obter vantagem competitiva sustentável e melhorar seu desempenho (BARNEY et al.,1991; ARGOTE e INGRAM, 2000). Por sua vez, a gestão do conhecimento apresenta um vasto campo teórico que este trabalho não pretende abranger, concentrando-se, de forma ainda que não exaustiva, na transferência interna dos conhecimentos sobre as rotinas organizacionais, inter áreas e intra equipes. Entende-se como transferência de conhecimentos ${ }^{3}$ nas organizações o processo por meio do qual uma unidade de negócios (área, divisão ou departamento) é afetada pela experiência de outra (ARGOTE, 2003).

As rotinas organizacionais resumem o que as empresas fazem e como fazem, sendo um produto da aprendizagem organizacional (ARGOTE, 2003) e, por essa definição, são formas de transferência de conhecimento organizacional. Levitt e March (1988), apontam a rotina como um mecanismo básico para a aprendizagem organizacional e Pentland et al., 2012 afirmam que o aprendizado organizacional é baseado nas rotinas. Feldman (2003) destaca, também, as rotinas como capacidades organizacionais e conhecimento codificado e estocável que se apresentam como componentes chaves no processo de aprendizagem organizacional, reforçando que a estrutura da rotina, como

\footnotetext{
${ }^{3}$ Este conceito se refere à transferência de conhecimento em um sentido mais amplo, não apenas à transferência de informações entre pessoas, mas à replicação de rotinas para novos contextos organizacionais, que não será abordado neste trabalho.
} 
elemento mais estável, cumpre bem esse papel. A autora salienta, ainda, o aspecto ostensivo da rotina como um estoque de conhecimento socialmente distribuído, mas, atribui ao aspecto performativo uma distribuição desigual de conhecimento. Dosi, Nelson e Winter (2000), que consideram as rotinas como um fenômeno coletivo, justificam que o conhecimento está disperso nas organizações e cada membro possui domínio sobre determinado fragmento, sendo que a troca de informações, percepções e conhecimentos é fundamental a fim de desenvolver o trabalho.

Sem as rotinas organizacionais, as empresas perderiam eficiência nas ações coletivas, muito embora, conforme afirmam Cohen e Bacdayan (1994), as ações repetitivas transferidas para situações inapropriadas podem prejudicar o desempenho. Estes mesmos autores salientam que a dificuldade em transmitir o conhecimento sobre as rotinas se deve a alguns fatores: elas são desempenhadas por vários atores, portanto, mais difícil de observar do que fenômenos individuais; a qualidade emergente das rotinas varia de acordo com o poder e subjetividade da agência (FELDMAN e PENTLAND, 2003), trazendo evolução para os padrões de comportamento pelas experiências dos usuários; e, por último, o conhecimento subjacente das partes da rotina realizadas pelos participantes é parcialmente desarticulado.

As rotinas organizacionais são constituídas pelos conhecimentos sociais dos seus participantes e pelas estruturas materiais, promovidas pelos artefatos físicos. As novas tecnologias trazem mudanças para a forma com que as pessoas se comunicam, organizam e agem nas suas relações sociais (LEONARDI, et al. 2012), tendo em vista que computadores, softwares e sistemas tecnológicos têm um potencial transformador e permitem o controle de ações de forma supostamente mais precisa, rápida e efetiva. Portanto, as novas tecnologias vêm reconfigurando as práticas sociais, concebendo a estrutura material e a agência como processos "inseparavelmente ligados", constituindo um fenômeno sociomaterial que, de acordo com Leonardi et al. (2012), é definido por insights coletivos que as pessoas têm ao utilizar as propriedades das tecnologias, as quais transcendem tempo e espaço, a fim de produzir artefatos para diferentes funções. Complementando esta ideia, Orlikowski (2007) aponta que não há social que não seja, também, material e nem material que não seja, também, social. 
Tal emaranhado entre o material e o social constitui a tecnologia e sugere que o conhecimento sobre as rotinas organizacionais seja um fenômeno sociomaterial, com implicações intrínsecas à prática organizacional (HILARICUS, 2011). Neste sentido, entende-se que as tecnologias, assim como as pessoas, contribuem para a vida organizacional. $\mathrm{O}$ uso da sociomaterialidade ${ }^{4}$ para a construção e transferência de conhecimento acontece a partir dos efeitos das práticas sociais que moldam os artefatos materiais inerentes à tecnologia e permitem que as informações permeiem o ambiente organizacional e sejam disseminadas (LEONARDI, 2012).

Outra proposta sobre a transferência do conhecimento de rotinas é o "reservatório de conhecimentos", desenvolvido por McGrath e Argote (2001), relacionando-se ao conhecimento incorporado nos três elementos básicos da organização e suas combinações: as pessoas, as ferramentas e as tarefas. Estes componentes são encontrados nas rotinas, cujas conexões ${ }^{5}$ entre seus participantes constituem mecanismos capazes de promover a estabilidade ou a mudança da rotina organizacional. O indivíduo desenvolve a tarefa a partir dos entendimentos sobre as ações que devem ser executadas em uma rotina específica e precisa entender o quanto esta ação está associada ao contexto organizacional. O compartilhamento destes entendimentos ajuda a empresa a manter os padrões de comportamento que orienta as ações dos indivíduos, enquanto as adapta às variações nos ambientes internos e externos (FELDMAN e RAFAELI, 2002).

Se a criação e transferência de conhecimento são a base da vantagem competitiva das empresas (ARGOTE e INGRAM, 2000), logo, entende-se que a replicação das rotinas para novos contextos se trata de uma estratégia de criação de valor para as organizações (FRIESL e LARTY, 2013; PARMIGIANI, et al., 2011). Argote e Ingram (2000) afirmam que a transferência de conhecimento pode ser medida a partir da mudança do conhecimento e da mudança da performance organizacional.

\footnotetext{
${ }_{5}^{4}$ Fusão entre os termos social e materialidade (LEONARDI, 2012).

5 Elementos de comunicação em rede com resultados chaves que provêm suporte social e transferência de informações (FELDMAN e RAFAELI, 2002).
} 
Porém, Argote (2000) reforça que a transferência efetiva de conhecimento pode variar de empresa para empresa e de área para área e, em seu trabalho sobre curvas de aprendizagem (DARR e ARGOTE, 1999 in PARMIGIANI et al., 2011), demonstra como as melhorias nas rotinas organizacionais podem ser transferidas para outras unidades, muito embora os autores admitam que se trate de um processo complicado, que requer desde a análise de nível individual até altos níveis dentro da organização. Witt (2011) corrobora que as rotinas são formadas através de processos coletivos que emergem dentro do contexto organizacional e que dependem de atitudes cognitivas e motivacionais dos membros da organização para acontecerem, muito embora o desempenho da rotina sugira uma perspectiva individual. Pentland e Feldman (2005) apontam que algumas rotinas são fáceis de transferir e outras não. Por último, Lazaric (2003) reflete que, mesmo com a evolução dos estudos sobre o tema rotinas organizacionais, alguns conhecimentos ainda precisam ser descobertos: como as rotinas surgem, em qual contexto e como elas são elaboradas uma vez que estão inseridas em várias camadas organizacionais que suportam e permitem sua criação. 


\section{3. Metodologia da pesquisa}

Este capítulo pretende apresentar a forma como este estudo foi realizado. Está dividido em quatro seções que informam o tipo de pesquisa, apresentando a finalidade e os meios empregados, os critérios de seleção de sujeitos que compõe a amostra, os processos de coleta de dados realizados e, por fim, os procedimentos de tratamento dos dados coletados e a análise.

\section{1.}

\section{Tipo de pesquisa - fins e meios}

As rotinas de compra de insumos químicos, suas partes e interações foram consideradas como unidades de análise, pois, segundo Pentland e Hærem (2015), "tratar os padrões de ações interdependentes como unidades de análise implicam em uma variedade de tópicos que explicam o comportamento organizacional". Também, segundo Lazaric (2003), o conhecimento sobre rotinas organizacionais requer sistematização para oferecer certa abundância de subsídios e evidências para a identificação de lacunas nas rotinas existentes ou a necessidade de ferramentas e artefatos. Portanto, quanto a sua finalidade, esta pesquisa pretendeu investigar as rotinas de compra de insumos químicos para entender os fatores que motivam suas variações. Conforme D'Adderio (2008), a investigação dos mecanismos internos da rotina vem proporcionando cada vez mais entendimento teórico para a construção da Teoria das Rotinas Organizacionais.

Quanto aos meios, este estudo possui natureza qualitativa e buscou explorar o estudo de caso único como estratégia de pesquisa. Segundo Yin (2003), o estudo de caso único exige uma investigação cuidadosa para minimizar equívocos e maximizar a coleta das evidências. O rigor na condução desta pesquisa foi reverenciado no uso de um conjunto de evidências, considerando a subjetividade natural do método (YIN, 2003).

A investigação de campo contou com entrevistas, observações empíricas e pesquisa documental dos artefatos existentes na empresa. Também pretendeuse sondar, identificar e recomendar soluções e ajustes para as melhorias necessárias às rotinas de compra. 


\section{2.}

\section{Seleção dos sujeitos}

A investigação das rotinas de compra foi feita por meio de pessoas do nível estratégico, tático e operacional, que detalhassem os aspectos da rotina, conforme os preceitos sugeridos por Pentland e Feldman (2005) e apontados por Turner e Rindova (2012), para captar múltiplas visões.

As rotinas de compras de insumos químicos permeiam duas das três áreas participantes desta pesquisa: o "Instituto A", com 50 pessoas; e a área de Compras, com 150 pessoas. A área de Processos, com menos de dez pessoas, é um importante ator no contexto desta pesquisa, por ter conhecimento sobre as rotinas de compras e por estar desenvolvendo um trabalho de melhoria nesses processos. Uma amostra de cada área participou das entrevistas, somando o total de 18 pessoas. O Quadro 1 apresenta as informações sobre os participantes das entrevistas.

Quadro 1: Resumo dos Participantes das Entrevistas

\begin{tabular}{|c|c|c|c|c|c|}
\hline Cód. & Área & Ator & $\begin{array}{c}\text { Nivel } \\
\text { Hierárquico }\end{array}$ & $\begin{array}{c}\text { Experiência } \\
\text { na área }\end{array}$ & $\begin{array}{l}\text { Duraçáo da } \\
\text { Entrevista }\end{array}$ \\
\hline $\mathrm{C} 1$ & \multirow{8}{*}{ Compras } & Gerente Geral de Compras & Estratégico & 29 anos & $58^{\prime}$ \\
\hline $\mathrm{C} 2$ & & Gerente de Compras & Estratégico & 26 anos & $54^{\prime}$ \\
\hline $\mathrm{C} 3$ & & Chefe de Setor de Compras & Tático & 10 anos & $50^{\prime}$ \\
\hline $\mathrm{C} 4$ & & Chefe de Setor do Planejamento e Cadastro de Materiais & Tático & 2,5 anos & $47^{\prime}$ \\
\hline $\mathrm{C} 5$ & & Coordenador do Centro de Distribuição & Tático & 4,5 anos & $1 \mathrm{H}$ e $18^{\prime \prime}$ \\
\hline C6 & & Almoxarife & Operacional & 9 anos & $34^{\prime}$ \\
\hline $\mathrm{C} 7$ & & Compradora 1 & Operacional & 2,5 anos & $42^{\prime}$ \\
\hline $\mathrm{C} 8$ & & Compradora 2 & Operacional & 1 ano & $46^{\prime}$ \\
\hline \multirow{2}{*}{ P1 } & \multirow{2}{*}{ Processos } & Gerente de Processos & Estratégico & \multirow{2}{*}{4 anos } & \multirow{2}{*}{$44^{\prime}$} \\
\hline & & Especialista em Processos & Tático & & \\
\hline $\mathrm{T} 1$ & \multirow{8}{*}{ "Instituto A" } & \begin{tabular}{|l} 
Gerente do "Instituto A" \\
\end{tabular} & Estratégico & 7 anos & $38^{\prime}$ \\
\hline $\mathrm{T} 2$ & & Chefe de Setor da Metrologia & Estratégico & 1,5 anos & $51^{\prime}$ \\
\hline T3 & & Chefe Administrativo Financeiro & Tático & 5 anos & $56^{\prime}$ \\
\hline $\mathrm{T} 4$ & & Especialista de Laboratório 1 & Tático & 8 anos & $25^{\prime}$ \\
\hline T5 & & Especialista de Laboratório 2 & Tático & 1 ano & $36^{\prime}$ \\
\hline T6 & & Analista Técnico de Laboratório & Operacional & 6 anos & $25^{\prime}$ \\
\hline $\mathrm{T7}$ & & Assistente Administrativa 1 & Operacional & 6 anos & $28^{\prime \prime}$ \\
\hline T8 & & Assistente Administrativa 2 & Operacional & 8 anos & $13^{\prime}$ \\
\hline
\end{tabular}

Fonte: Elaborado pela pesquisadora com base nas entrevistas.

A seleção de alguns sujeitos da área de compras foi a utilização do método "bola de neve", onde um participante indica outro participante a ser entrevistado (GOODMAN, 1961). Este método foi útil por ter estabelecido uma relação de confiança entre o entrevistado e a pesquisadora (BIERNACKI e WALDORF, 1981). 


\section{3.}

\section{Fontes de evidências}

Os dados foram coletados a partir das três formas apresentadas na Figura 5, escolhidas por apontar um caminho adequado para a busca das informações para a construção de um banco de dados para a análise.

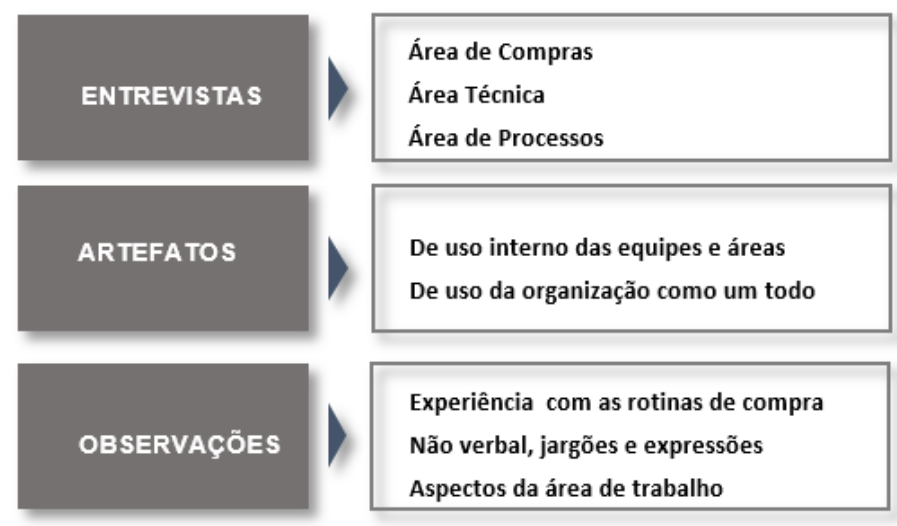

Figura 5: Formas utilizadas para a coleta de dados

Fonte: Elaborado pela pesquisadora com base nos dados coletados.

O Quadro 2 descreve cada uma das fontes de evidências utilizadas e o conteúdo compilado de cada delas. Os artefatos estão listados no APÊNDICE A deste documento. É importante salientar que não houve a autorização da empresa para anexar a este trabalho os artefatos de compra utilizados na pesquisa, como os regulamentos, normas e procedimentos.

Quadro 2: Fontes de Evidências e descrição

\begin{tabular}{|l|l|}
\hline \multicolumn{1}{|c|}{ Fonte de Evidências } & \multicolumn{1}{c|}{ Descrição } \\
\hline Artefatos & $\begin{array}{l}\text { Organogramas, Fluxos de trabalho, Listagem de planejamento de } \\
\text { compras, Fluxo paralelo de compras, Matriz de problemas, Checklit } \\
\text { de recebimento de material e a nova Ficha de especificação de } \\
\text { produto. Regulamento de licitações e de compras, Acordo de nível de } \\
\text { serviço, Processo oficial de compras, Norma administrativa de } \\
\text { aquisição de bens e serviços, Instruções operacionais de cada etapa } \\
\text { do processo de compras e Ficha de Especificação de Produto. }\end{array}$ \\
\hline Entrevistas & $\begin{array}{l}\text { Relatos, narrativas e depoimentos dos 18 participantes da pesquisa, a } \\
\text { partir de um roteiro semi estruturado. }\end{array}$ \\
\hline Observações de campo & $\begin{array}{l}\text { Experiência da compra e aspectos não verbais dos entrevistados, } \\
\text { impressões das entrevistas, aspectos do ambiente de trabalho. }\end{array}$ \\
\hline
\end{tabular}

Fonte: Elaborado pela pesquisadora. 


\subsection{1.}

\section{Procedimentos e instrumentos de coleta de dados}

Os três princípios preconizados por Yin (2003) para a coleta dos dados foram considerados neste trabalho: a utilização de várias fontes de evidências; a criação de um banco de dados para o estudo de caso; e a manutenção do encadeamento das evidências.

A coleta de cada tipo de evidência seguiu uma estratégia diferente. As entrevistas foram realizadas a partir de um questionário semiestruturado, de forma individual e gravadas com o consentimento dos entrevistados, nos seus respectivos locais de trabalho, a fim de deixá-los à vontade para falar. instrumento utilizado para a coleta de dados de entrevista está disponível no APÊNDICE B deste documento e sua construção teve base nas teorias apresentadas no Capítulo 2. É importante relatar que o instrumento de pesquisa foi constituído com a intenção de propiciar a participação todos os atores, muito embora algumas perguntas de estímulo tenham sido feitas para alguns atores. A partir das respostas dos participantes foi possível fazer perguntas não previstas e necessárias para o entendimento de alguns tópicos, conforme preconizado por Yin (2003).

À medida que os entrevistados falavam, iam exemplificando e apresentando os artefatos utilizados na pesquisa, apoiando, corroborando e valorizando o conteúdo levantado durante as entrevistas. Portanto, houve a permissão formal, sugerida por Yin (2003), para examinar os arquivos da organização estudada, muito embora não tenha sido permitida a inserção deles nesta pesquisa. Por último, conforme preconizam Feldman e Pentland (2008), as observações empíricas da compra foram realizadas, em grande parte, dentro do "Insituto A", sem interação com a pesquisadora a fim de não influenciar o processo, muito embora haja uma limitação nesse sentido.

A coleta de dados aconteceu no período entre 24/08/2015 a 29/01/2016, iniciando pelas observações empíricas e busca de artefatos. As entrevistas aconteceram entre os dias 07/12/2015 e 18/12/2015 e suas transcrições conservaram os jargões e expressões dos participantes. Além disso, foram feitas várias anotações sobre aspectos não verbalizados pelos entrevistados e sobre a aparência geral do ambiente de trabalho, úteis para enriquecer a análise. As transcrições de mais de 12 horas de gravação geraram 84 páginas de conteúdo. 


\section{4.}

\section{Trabalho de campo}

Inicialmente, o convite para os atores da área de compras participarem das entrevistas foi feito via e-mail. Porém, nem todos pareceram confortáveis em participar e, com alguns, foi necessária certa insistência, configurando-se o primeiro obstáculo do trabalho de campo. Uma preocupação da pesquisadora foi expressar que seria adotada uma posição neutra e imparcial, chancelada pela necessidade de investigar aspectos dentro do contexto organizacional para um trabalho acadêmico de mestrado ${ }^{6}$, a fim de deixar os atores um pouco mais à vontade para falar.

A área de processos teve um papel fundamental com posicionamento neutro, sendo totalmente solidários com a investigação. Inclusive, tendo contribuído com a documentação oficial e com um levantamento de problemas no processo de compras.

Ficou claro durante as entrevistas que alguns atores da área de compras não estavam familiarizados com as rotinas de compras dos insumos do "Instituto A", passando exemplos fora do contexto da pesquisa. Nesse caso era solicitado ao entrevistado a lembrança de um outro exemplo mais aderente ao contexto e, algumas vezes, essa tática ajudou, mas, em outras não. Contudo, houve aderência e colaboração das três áreas para a pesquisa.

A observação das performances da rotina de compras de insumos químicos dentro da área de compras não foi autorizada pelos gestores. No dia da entrevista com os compradores houve a possibilidade de observações de performance de compra, pois a entrevista foi realizada na área de trabalho dos mesmos. A ausência da observação da performance da compras pelos compradores não trouxe grande prejuízo para a pesquisa, pois o "Instituto A" realiza a maior parte das compras de insumos químicos (89\%), as quais foram observadas de forma distribuída no tempo, no espaço e entre vários participantes (PENTLAND e FELDMAN, 2005; PENTLAND e FELDMAN, 2008).

\footnotetext{
${ }^{6}$ O roteiro da entrevista tinha a logomarca da PUC Rio para transmitir aos participantes a neutralidade e imparcialidade da investigação.
} 


\section{5.}

\section{Tratamento dos dados e procedimentos de análise}

A análise envolveu o inter-relacionamento entre os relatos dos indivíduos sobre as rotinas de compra, os artefatos e as observações de campo. A triangulação dos dados levantados com as teorias abordadas no estudo, apontou conformidades e não conformidades, a partir das categorias de informações. A Figura 6 ilustra esta técnica de análise.

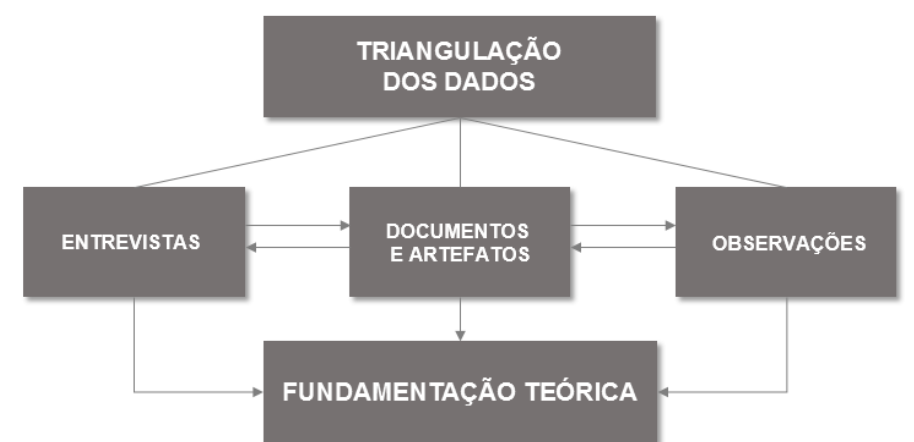

Figura 6: Triangulação dos dados para a análise Fonte: Oliveira, 2010.

Yin (2003) aponta que a organização dos dados coletados é a base para iniciar o trabalho e pode ser montada a partir das pesquisas de campo, documentos e observações. O tratamento dos dados levantados durante a fase da coleta teve por objetivo principal o encadeamento das evidências para propiciar sua triangulação, além da criação de um banco de dados que facilitasse o trabalho de análise. Além disso, houve o propósito de redução dos dados em unidades fáceis de analisar. Portanto, após as transcrições das entrevistas, o conteúdo foi lido e categorizado em blocos de informações a fim de criar uma matriz que permitisse facilitar a análise, originando um grande banco de dados em Excel (YIN, 2003), onde a ideia central dos depoimentos foi comparada com os artefatos e observações de campo para entender se existiam aderências ou divergências. Por último, foi verificado se a teoria sobre as rotinas organizacionais provê suporte para os achados. 


\subsection{1.}

\section{Banco de dados}

A criação do banco de dados foi um dos princípios observados durante o desenvolvimento desta pesquisa, cuja organização visou a permitir a acessibilidade e rastreabilidade. Após a realização das entrevistas e observações todo o conteúdo gravado foi transcrito, gerando um grande banco de dados bruto. Os documentos e artefatos foram catalogados e dispostos em uma espécie de bibliografia comentada, como orienta Yin (2003), de acordo com o seu tipo para serem usados na triangulação dos dados para a análise. A Tabela 1 a seguir apresenta parte da matriz gerada na triangulação de dados.

\begin{tabular}{|c|c|c|c|}
\hline \multirow[b]{2}{*}{ FONTES } & \multicolumn{3}{|c|}{ CATEGORIAS } \\
\hline & $\begin{array}{l}\text { CATEGORIA } 1 \\
\text { Alinhamento de papéis, conceitos e interesses }\end{array}$ & $\begin{array}{c}\text { CATEGORIA 2 } \\
\text { Estruturaçăo e fundamentação das } \\
\text { Rotinas Organizacionais }\end{array}$ & $\begin{array}{c}\text { CATEGORIA } 3 \\
\text { Relação entre as } \\
\text { partes da Rotina } \\
\text { Organizacional } \\
\end{array}$ \\
\hline Entrevistas & $\begin{array}{l}\text { (1) Conceito, necessidade e interesse } X(\mathrm{C} 1, \mathrm{C} 2, \mathrm{C} 3, \mathrm{C} 4) \\
\text { (2) Conceito, necessidade e interesse } \mathrm{Y}(\mathrm{C} 5, \mathrm{C} 6, \mathrm{C} 7, \mathrm{C} 8, \mathrm{T1} \\
\mathrm{T} 2, \mathrm{~T} 3, \mathrm{~T} 4, \mathrm{~T} 5, \mathrm{~T} 6, \mathrm{~T} 7, \mathrm{~T} 8, \mathrm{P} 1)\end{array}$ & $\begin{array}{l}\text { Faptura do Aspecto Ostensivo: } \\
\text { (1) Narrativa Compras (C1, C2, C3, C4, C5, C6, C7, C8) } \\
\text { (2) Narrativa Técnica (T1, T2, T3, T4, T5, T6, T7, T8) } \\
\text { (3) Narrativa Processos (T1) }\end{array}$ & \\
\hline $\begin{array}{l}\text { Análise } \\
\text { Documental }\end{array}$ & \begin{tabular}{|l|} 
(1) Regulamento de Compras, Norma Administratica de \\
Compras, Instruções Operacionais de Compras; Fluxograma \\
da área de compras, fluxo de compras. \\
(2) Acordo de Nivel de Serviço.
\end{tabular} & $\begin{array}{l}\text { aptura dos Artefatos: } \\
\text { 1) Processo de compras oficial e com base em licitações } \\
\text { 2) Processo de compras paralelo e com base em compras de } \\
\text { pequenos lotes }\end{array}$ & \\
\hline $\begin{array}{l}\text { Observaçöes } \\
\text { Gerais }\end{array}$ & \begin{tabular}{|l|} 
(1) Sala separada, formalismo na comunicação, burocracia, \\
exemplos fora do contexto (C1, C2, C3, C4, C5, C6, C7) \\
(2) Conhecimento tácito das rotinas, interesse em ajudar (T1, \\
T2, T3, T4, T5, T6, T7, T8)
\end{tabular} & $\begin{array}{l}\text { 1) Trabalho em silos, sala desorganizada, uso intensivo do e- } \\
\text { mail para a comunicaçăo, receio em responder aos } \\
\text { questionamentos da entrevista, escolha das palavras. } \\
\text { (2) Ambiente informal dentro do mesmo laboratório, porém, } \\
\text { desintegrado entre os laboratórios. }\end{array}$ & \\
\hline $\begin{array}{l}\text { Observações de } \\
\text { Performance }\end{array}$ & Não se aplica a esta categoria & $\begin{array}{l}\text { Captura do Aspecto Performativo: } \\
\text { (1) Disponibilidade parcial do aspecto performativo na área de } \\
\text { compras (cotaçăo, estocagem e dossiê da compra). } \\
\text { (2) A maior parte das ações de compra foram observadas na } \\
\text { área técnica (cotaçăo, abertura de SA e SC, autorização da } \\
\text { compra, acompanhamento de pedido). Certa familiaridade com } \\
\text { os fornecedores. }\end{array}$ & \\
\hline Suporte teórico & $\begin{array}{l}\text { Encontra apoio nos construtos de Feldman (2000 e 2003); } \\
\text { Pentland e Feldman (2008), Pentland e Feldman (2008), } \\
\text { Lazaric (2003), Cyert e March (1963), Simon (1957), Nelson e } \\
\text { Winter (1982). }\end{array}$ & $\begin{array}{l}\text { Encontra apoio nos construtos de Feldman (2000; 2003; 2004), } \\
\text { Feldman e Pentland (2003), D'Adderio (2008; 2011); Pentland e } \\
\text { Feldman (2005; 2008), Leonardi et al. (2012), Turner e Rinova } \\
\text { (2012); Cohen e Bacdayan (1994); Lazaric (2011); Leonardi } \\
\text { (2012), Miller et al (2012); Pentland e Hærem (2015); Cohen } \\
\text { (2007) }\end{array}$ & \\
\hline
\end{tabular}

Tabela 1: Matriz gerada na triangulação dos dados

Fonte: Elaborada pela pesquisadora a partir da análise de dados.

3.6.

\section{Limitações do método}

A característica desestruturada dos dados de um Estudo de Caso justifica a necessidade de cuidado para o estabelecimento de modelos de análise (YIN, 2003). Esta limitação do método justifica o uso de estratégias que garantam a qualidade da pesquisa, a validade do construto e a confiabilidade. Sendo assim, a análise dos dados coletados se baseou no tratamento das evidências de forma justa, a fim de produzir conclusões analíticas irrefutáveis e eliminar falsas interpretações, permitindo a extração de sentido (YIN, 2003; OLIVEIRA, 2010; CRESWELL, 2010). 
Outra limitação observada foi na escolha dos sujeitos da área de compras a partir do método "bola de neve", pois há a tendência de indicação dos membros menos susceptíveis a exporem a área, tornando os resultados passíveis de não generalização (BICKMAN e ROG, 1997).

A presença de uma pessoa observando a performance da compra pode ter alterado a forma como a compra é realizada, muito embora tenha sido uma observação discreta. Talvez a utilização de materiais audiovisuais da performance da compra pudesse garantir menor interferência à observação. 


\section{4. \\ Estudo de caso}

\section{1.}

A empresa objeto de estudo

A fim da preservação da identidade e manutenção do sigilo a empresa e unidade de negócio abordadas neste estudo receberam cognomes.

Com mais de 60 anos no mercado, a "Organização S" atua no âmbito do estado do Rio de Janeiro, posicionando-se como um importante colaborador para o desenvolvimento da indústria fluminense com a geração e disseminação de conhecimento técnico e tecnológico através de várias unidades de negócio. Conta com uma estrutura organizacional robusta com áreas para suporte institucional, cujas rotinas organizacionais formam uma cadeia de valor interna para atender as unidades de negócio, com recursos humanos, finanças e contabilidade, planejamento e processos, compras e suprimentos, comunicação e marketing, jurídico, entre outras.

Dentre suas unidades de negócios, atualmente, possui 4 institutos de tecnologia, que atuam provendo soluções para viabilizar processos industriais eficientes por meio de serviços de consultoria, metrologia e PD\& ${ }^{7}$, baseados em diferentes áreas de conhecimento. Esta pesquisa focou em um dos institutos de tecnologia da "Organização S", o qual atua na área de meio ambiente e química, chamado de "Instituto A". A Figura 7 ilustra a empresa objeto de estudo, a área de compras, responsável pelas rotinas abordadas neste trabalho, e a unidade de negócio impactada pela rotina de compras, ou seja, o "Instituto A".

\footnotetext{
${ }^{7}$ Pesquisa, Desenvolvimento e Inovação.
} 


\section{Organização S}

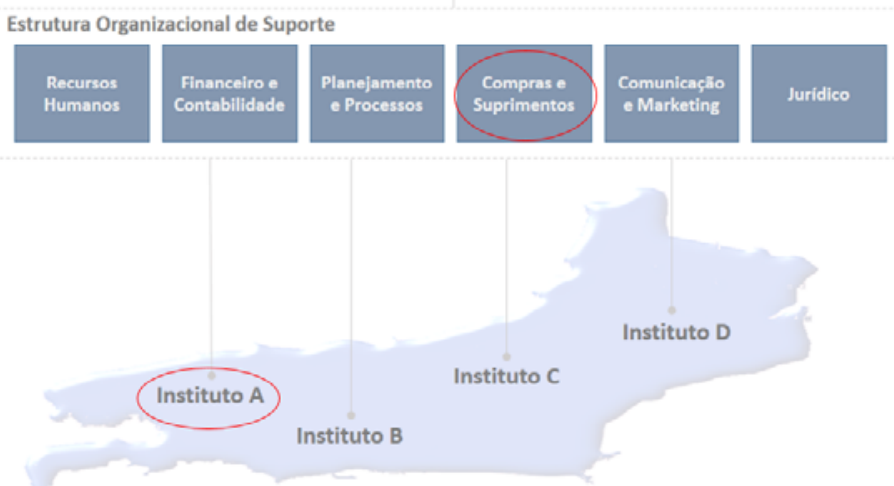

Figura 7: Empresa objeto de estudo

Fonte: Elaboração própria

\section{2. \\ O contexto organizacional}

As indústrias sofrem pressões de múltiplos stakeholders para minimizarem o impacto ao meio ambiente e proverem a saúde e a segurança do trabalhador. As exigências legais são controladas por órgãos específicos, cuja fiscalização constante é de crescente interesse para toda a sociedade para o controle de aspectos nocivos e prejudiciais às pessoas e ao ecossistema. As boas práticas são exigidas em toda a sua cadeia de suprimentos, fazendo com que as medidas de responsabilidade socioambiental transcendam a questão da conscientização e tomem um caráter de retorno financeiro, considerando as várias dimensões da sustentabilidade (SACHS, 2002).

É neste contexto que o "Instituto A" presta serviços de análises metrológicas de Toxicologia, Higiene Ocupacional e Meio Ambiente às indústrias, as quais buscam aferir alguns parâmetros importantes para o controle dos impactos ao meio ambiente a à saúde do trabalhador. A partir de resultados conformes com a legislação, essas indústrias recebem certificações, licenças e chancelas dos órgãos responsáveis, comprovando a operação dentro de preceitos legais em relação aos impactos socioambientais, o que legitima e justifica a importância e a responsabilidade de prover serviços tecnológicos com a máxima eficiência, agilidade e rapidez, garantindo laudos técnicos precisos. 
Desde 2001, o "Instituto A" vem sendo reconhecido como parceiro da indústria, apoiando os processos produtivos sustentáveis. Empresas oriundas de todo o país buscam seus serviços em química ambiental devido à variedade de análises que é capaz de realizar, a partir da sua planta laboratorial e equipe técnica altamente especializada.

Impelida pelo rigor das leis ambientais do Brasil, a demanda por esses serviços aumentou de forma expressiva nos últimos anos, seguindo uma característica de contratos anuais de serviços de análises, em geral, baseados em licitações de grandes empresas públicas e privadas; além de uma característica de pronto atendimento, com análises pulverizadas para um grande número de clientes. Esses dois perfis de demandas exigem uma gestão diferenciada para a compra de insumos químicos.

As competências do "Instituto A" são baseadas em um tripé onde em um dos pilares estão os equipamentos, instrumentos e estrutura laboratorial; em outro pilar está a equipe técnica altamente capacitada a desenvolver ensaios e métodos analíticos baseados em processos químicos; e, por último, os insumos químicos utilizados nas análises, como reagentes, diluentes, substâncias, além da vidraria e recipientes para a coleta de amostras. A falta de qualquer um desses pilares inviabiliza a operação do "Instituto A".

Os insumos utilizados nas análises possuem características incomuns. Trata-se de substâncias combinadas ou não com outros elementos, cujos nomes são oriundos de moléculas químicas complexas, apresentadas em diferentes graus de pureza para serem utilizadas de acordo com o tipo de análise ou nível de confiança pretendido pelo cliente. Algumas delas constituem materiais de referência ou padrões certificados e, outras, podem exigir autorização para uso de órgãos específicos como o Ministério da Saúde, Polícia Federal, entre outros. Além disso, a maioria delas exige armazenagem dentro de padrões rigorosos de segurança. Contudo, essas substâncias podem ser commodities ou especialidades, conforme Silva (2011) ${ }^{8}$. Como o Brasil não sintetiza boa parte dos insumos para a indústria química, muitas deles são importados, variando sua apresentação ou embalagem. Outra particularidade relevante é a característica da cadeia de fornecedores desses insumos, que é bastante restrita, além de ser muito difícil reunir em um só fornecedor uma gama

${ }^{8}$ Commodities são produtos fabricados em grandes quantidades, utilizando principalmente processos contínuos, com especificações padronizadas e preços menores. Especialidades são normalmente produzidas de acordo com as especificações de um cliente, como um determinado grau de pureza ou propriedade física, cujos preços são mais elevados (BNDES Setorial Química, 33, p 349-378). 
diversificada de insumos. Em geral os fornecedores trabalham com tipos específicos de insumos químicos ${ }^{9}$.

Como a "Organização S" gera dinheiro público, possui processos que são auditados pelo Tribunal de Contas da União (TCU) e Corregedoria Geral da União (CGU), entre eles, o processo de compras e aquisições dos insumos para a operação do "Instituto A". Para dar suporte à compra dentro dos preceitos legais, a "Organização $S$ " segue um regulamento institucional de compras baseado na Lei $n^{0} 8.666^{10}$, que apresenta as diretrizes e princípios a serem seguidos.

Basicamente, o regulamento de compras aponta a necessidade de licitar toda e qualquer compra de consumíveis utilizados por quaisquer unidades da "Organização S", superior a R\$ 44.000, por fornecedor. Portanto, todas as compras inferiores a este valor terão dispensa de licitação. Este caso é aplicável à compra de pequeno volume ou insumos muito específicos. São as chamadas "aquisições diretas", que para os insumos químicos, devem acontecer mediante algumas circunstâncias ${ }^{11}$ e cumprindo algumas regras ${ }^{12}$.

A área de compras provê dois dos três pilares do referido tripé de competências do "Instituto A": a aquisição e manutenção de equipamentos e aquisição insumos químicos. Nesse sentido, o "Instituto A" é um cliente interno desta área, principalmente para compra de insumos, cuja demanda é bastante heterogênea ${ }^{13}$. E para atender a demanda por suprimentos, a área de compras se estruturou de acordo com a Figura 8. O Setor de Compras é responsável pelas compras em todas as modalidades ${ }^{14}$; e o Setor de Cadastros realiza os cadastros de materiais e fornecedores, pois tudo deve estar devidamente registrado no sistema ${ }^{15}$, planeja as compras por licitação e coordena o Centro de Distribuição, que é responsável pelo Almoxarifado, que está localizado nas dependências do "Instituto A".

\footnotetext{
${ }^{9}$ Alguns atuam com sólidos, outros com líquidos, outros só com os controlados.

${ }^{10}$ Lei Federal que rege o processo de compras de empresas públicas. Entretanto, o regulamento interno apenas se baseia nessa lei, sem segui-la literalmente.

${ }^{11} \mathrm{Em}$ caso de emergência, quando caracterizada a necessidade de atendimento a situação que possa ocasionar prejuízo ou comprometer a segurança; ou em caso de urgência, para o atendimento de situações comprovadamente imprevistas ou imprevisíveis em tempo hábil para se realizar a licitação.

12. Compra de até R\$ 880: necessária autorização dos gestores.

- Compra superior a R\$ 880 e inferior a R\$ 44 mil: necessária autorização dos gestores e obrigatória a cotação com 3 fornecedores diferentes e apresentação de sua regularidade fiscal.

${ }^{13} \mathrm{Em}$ função das especificidades e peculiaridades dos insumos químicos.

${ }_{14}^{14}$ Por Licitação, por dispensa de licitação e por inexigibilidade.

${ }^{15}$ Módulo de Compras do Sistema ERP utilizado pela empresa.
} 


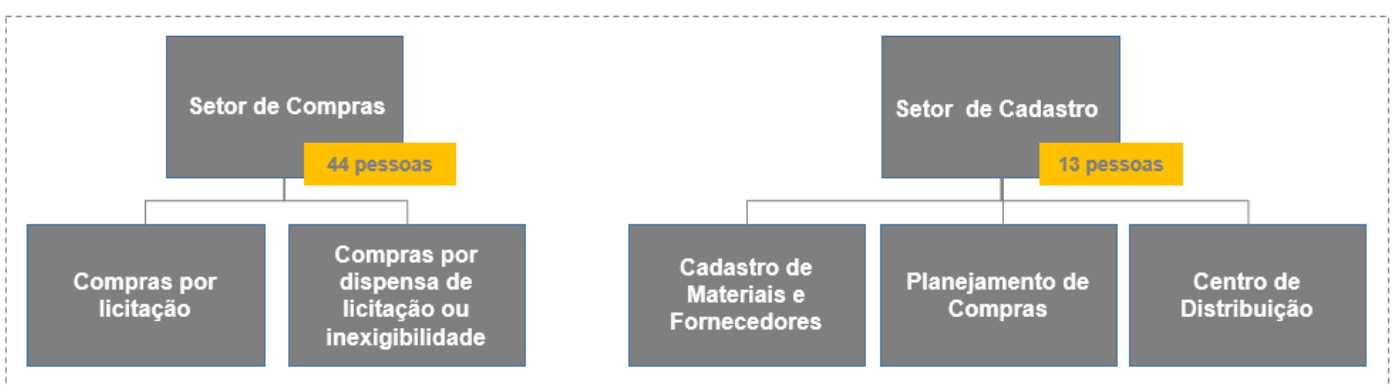

Figura 8: Estrutura da área de compras Fonte: Elaboração própria

A modalidade de compras por licitação é preconizada e apoiada pela área de compras, que precisa garantir a proteção institucional da empresa (HANNANA e FREEMAN, 1983). Portanto, as rotinas organizacionais de compras foram estruturadas de forma a promover as licitações, mantendo compras programadas, inclusive de insumos químicos.

Porém, há quatro ou cinco anos, a área de compras vem tendo dificuldade em prover um fluxo adequado de suprimentos, fazendo compras erradas, fora da especificidade, fora do prazo necessário. Essas desconexões têm acontecido em função de uma mudança no contexto organizacional, impulsionada pela alta demanda por serviços do laboratório, principalmente após as melhorias de equipamentos e tecnologias, que proporcionaram novos serviços de análises e requerem insumos diferenciados; e, também, pelo mercado fornecedor ter se reorganizado e trazido novidades de produtos, padrões, combinações de substâncias e outras facilidades para as análises. A área de compras passou a não acompanhar essas alterações e os materiais que estavam com compra programada ficaram obsoletos e não serviam mais para a operação. É neste contexto, impelido por uma real necessidade de suprimentos para operar, que as compras passam a ser realizadas pelos técnicos do "Instituto A", que desenvolveu a competência de comprar mediante "aquisição direta", por dispensa de licitação, uma vez que precisava de itens emergenciais para suportar sua operação ${ }^{16}$. A alta demanda impedia que os técnicos parassem para explicar as peculiaridades da compra de insumos para a área de compras. Até mesmo o distanciamento da comunicação entre ambas áreas intensificou o problema. Naquele momento, a atividade da compra era relevante para os técnicos no processo de operação do laboratório e o envolvimento da área de compras passou a ser apenas o fechamento da compra no sistema.

\footnotetext{
${ }^{16}$ A compra passou a ser realizada em pequenas quantidades para cumprir os preceitos do
} regulamento interno de compras. 
Esta forma de conduzir o processo de compras é considerada, pela área de compras, como prejudicial para a organização, pois vários pequenos pedidos para um mesmo fornecedor podem configurar fracionamento da despesa ${ }^{17}$, prática considerada ilegítima pelo TCU. Porém, foi a forma de garantir a operação das demandas emergenciais do "Instituto A".

Um trabalho ${ }^{18}$ realizado no mês de agosto de 2015 , junto aos técnicos do "Instituto A", salientou a dificuldade para comprar. Segundo os depoimentos dos técnicos durante este trabalho, a área de compras não sabe comprar insumos químicos e a área técnica aponta a dificuldade em seguir as regras internas do processo de compras. Para contornar essas dificuldades, hoje em dia, a área técnica do "Instituto A" realiza $89 \%$ das compras de materiais de consumo a partir da compra de pequenos lotes. Esta condição está sendo abordada neste estudo como uma "variação da rotina organizacional", a qual possui uma característica desfavorável, uma vez que atesta a ineficiência dos processos internos, além de comprometer a eficiência da produtividade do "Instituto A", passando, gradativamente, a responsabilidade pela performance da rotina organizacional de compra para outro ator, cujo papel não é performá-la. Segundo Feldman e Pentland (2003), a relação entre os aspectos ostensivo e performativo das rotinas organizacionais cria uma oportunidade para a variação positiva da rotina e é importante sondar se ela está acontecendo, a partir da performance da rotina organizacional pelos atores da área técnica.

\footnotetext{
17 Pode configurar a fuga da licitação para beneficiar fornecedores em particular ou fugir das regras de compra que protegem a empresa.

${ }^{18}$ A aplicação do MASP (método de análise e solução de problema), onde foi realizado um focus group com 40 técnicos dos laboratórios do "Instituto A".
} 


\section{5. \\ Análise dos resultados}

Esta pesquisa buscou compreender quais fatores motivam as variações na performance da rotina de compras. Para facilitar a análise, os dados coletados foram categorizados em seis grupos de informações, que representam os tópicos de análise dos resultados, conforme apresentado no Quadro 3.

Quadro 3: Categorias encontradas com a análise das transcrições

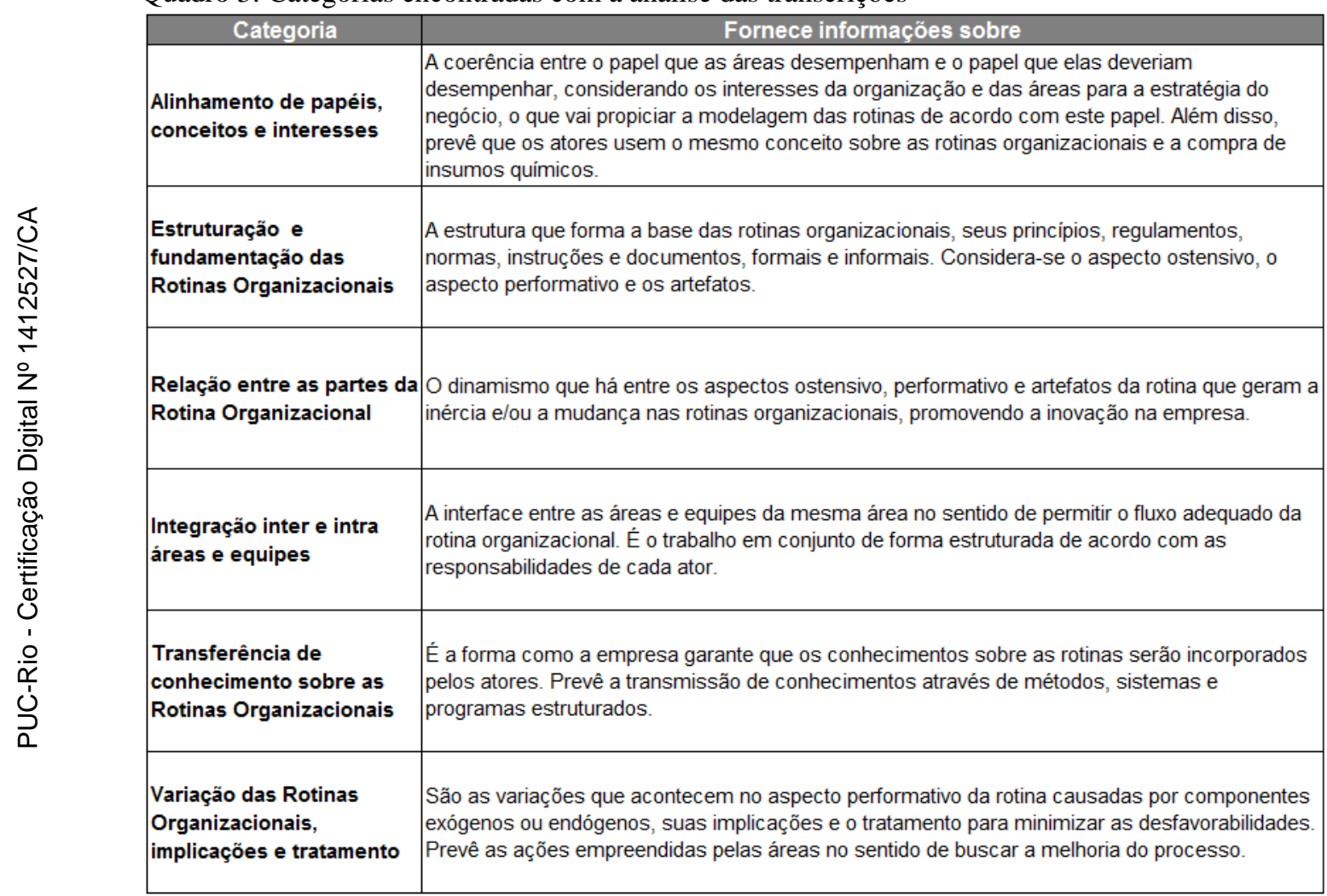

Fonte: Elaborado pela pesquisadora a partir da análise do conteúdo das entrevistas.

O fenômeno das rotinas organizacionais foi investigado dentro do contexto da empresa, tanto na área de compras, quanto na área técnica do "Instituto A", pois o conjunto de atores envolvidos na realização de uma rotina pode ser amplamente distribuído no tempo e no espaço (PENTLAND e FELDMAN, 2005), além de estarem inseridas em várias camadas organizacionais que suportam e permitem sua criação (LAZARIC, 2003). 
A primeira variação observada na rotina de compras, e que originou o interesse na pesquisa, foram as performances de compra a partir da área técnica em vez de serem realizadas ela área de compras. A triangulação dos dados permitiu a identificação de outras variações que serão apresentadas ao longo deste capítulo. A partir da compra realizada pela área técnica, considerada uma variação desfavorável e indesejáve ${ }^{19}$, acabou-se criando outras variações que possibilitaram a performance desejada dentro do prazo adequado, pois os elementos da rotina não mudaram, o que mudou foi a forma de realização (FELDMAN, 2000; FELDMAN, 2003). A mesma autora afirma que a forma de performar cada elemento da rotina traz implicações para esses elementos, bem como para o resultado da tarefa, sendo que alguns padrões podem sofrer variação e melhoria, embora os elementos sequenciais ainda estejam incluídos na rotina.

Os achados de cada uma das seis categorias serão abordados a seguir.

\section{1.}

\section{Alinhamento de papéis, conceitos e interesses}

Esta categoria buscou analisar se a rotina organizacional de compra possui estrutura adequada para atender às demandas do "Instituto A" por insumos químicos e se existe coerência conceitual sobre o que é comprar esse tipo de material.

Em relação ao alinhamento de papeis das equipes, reitera-se que a área de compras deve realizar as compras corporativas para a empresa como um todo, apoiando seus clientes internos, utilizando as normas e regulamentos internos de compra. A área técnica representada pelo "Instituto A" possui um papel de execução de análises, ensaios e calibrações para os clientes externos que demandam esses serviços, seguindo os procedimentos metodológicos. Portanto, é possível afirmar que há dois papéis distintos e importantes para cada área: atender a necessidade do cliente (interno e externo) e seguir as regras.

A metade dos entrevistados da área de compras $(C 1, C 2, C 3, C 5)$ afirmou que as rotinas está totalmente alinhado para atender ao regulamento de compras da empresa. O comentário de um deles reitera a necessidade do cumprimento das regras como uma premissa para a proteção institucional, porém, percebe de que o cumprimento das regras é uma aspecto que atrapalha o processo de operação do negócio:

\footnotetext{
${ }^{19}$ Porque interfere na produtividade dos técnicos do "Instituto A", que perdem tempo fazendo as compras de insumos.
} 
"[...] existe um tripé de defesa da organização, que é formado pelo jurídico, pela auditoria interna e pela nossa gerência (compras) [...]”; "[...]nós da área de compras somos considerados os caras que estão aí para atrapalhar." (Entrevista C2)

A outra metade dos entrevistados da área de compras (C4, C6, C7, C8) admite que a rotina organizacional de compras existente desconsidere 0 atendimento a necessidade do cliente interno, pois o cumprimento das regras e regulamentos aumenta o tempo para comprar. A área processos atestou que a área de compras não cumpre seu papel de parceiro das outras áreas para a realização das compras, estando muito presa às questões legais, fundamentando a ideia do atributo automático ligado à rotina e da concepção de irracionalidade, onde o executor não pensa para a sua execução (CYERT e MARCH, 1963; SIMON, 1957; NELSON e WINTER, 1982; FELDMAN, 2000; FELDMAN, 2003). Portanto, é tão mecânico o cumprimento do regulamento, que a necessidade do cliente interno acaba sendo suplantada. Da mesma forma, a área técnica, comentou a falta de parceria da área de compras:

[...] a gente ouve muito da área de compras é que ela é uma espécie de legalista e nós, não sendo legalistas, nós somos o quê, nós somos os fora da lei[...].(Entrevista T1)

Eu acho que a estrutura (da área de compras) que, às vezes, pode não estar de forma adequada para nos atender na velocidade que nós precisamos[...].(Entrevista T4)

Muitos artefatos acompanham as rotinas organizacionais (FELDMAN e PENTLAND, 2005). Os artefatos de compras existentes na empresa indicam o objetivo prioritário do cumprimento do regimento interno de compras. O único artefato que menciona a relação de parceria e atendimento às necessidades dos clientes internos é o "Acordo de Nível de Serviço ${ }^{20}$ - ANS", que apresenta em sua redação a parceria e a contínua busca por melhoria nos processos e serviços prestados além da responsabilidade em entregar produtos dentro dos níveis de qualidade e nos prazos, de acordo com as modalidades da compra. Portanto, a necessidade de atender regras não deveria sobrepujar o atendimento das necessidades do cliente interno, mas ser um compromisso concomitante. Contudo, o artefato não produz efeito.

20 Estabelece os padrões da prestação dos serviços de compras, com prazos para cada modalidade de compra. 
Em relação ao alinhamento de conceitos sobre a compra de insumos químicos, algumas contradições e incoerências foram observadas no discurso de um mesmo ator da área de compras, sugerindo que o conhecimento abstrato da rotina pode estar com indefinições que impactam na variação da performance (FELDMAN e PENTLAND, 2003).

[...] comprar aqui nesta empresa é uma rotina muito simples, muito padronizada [...] para nós é muito difícil comprar, somos uma organização privada, mas com processos quase que públicos...isso torna a nossa vida bem mais penosa...somos obrigados a cumprir determinadas rotinas que constam nas licitações... temos um processo com um peso burocrático muito alto [...] a gente tem um profissional de compras dedicado ao "Instituto A" [...] não existe dedicação de compradores a determinada área. (Entrevista C1)

O conceito da compra de insumos químicos está dividido dentro da área de compras. Os atores estratégicos $(\mathrm{C} 1, \mathrm{C} 2)$ afirmaram que a compra de insumos químicos é igual a qualquer compra, demonstrando não perceberem diferença sobre características. Um dos atores comentou sobre a compra de insumos químicos:

"Essa compra é igual a compra de lápis em função da especificação" [...] "eu compro material para aviação, para metrologia [...] "[...]não há dificuldade para a compra desses insumos"[...] "impossível que o meu comprador tenha dificuldades porque nós compramos materiais assim, assim...muito mais difíceis, muito mais específicos. E a gente consegue fazer isso com maestria". (Entrevistas C1 e C2)

Os demais atores da área de compras $(\mathrm{C} 3, \mathrm{C} 4, \mathrm{C} 5, \mathrm{C} 6, \mathrm{C} 7, \mathrm{C} 8)$ apontaram diferenças significativas na compra de insumos químicos e o quanto é difícil realizar esta aquisição, denotando certo desalinhamento conceitual da compra de insumos químicos dentro da própria área.

Da mesma forma, a área técnica apontou que as especificidades dos insumos qualificam esta compra como difícil, reiterando "isso é muito complexo até para um químico (entrevista T2)." A área de processos comentou que "as particularidades do serviço de Tecnologia, não ficam claras para a empresa como um todo (entrevista P1)", deixando explícito que há uma ausência de conhecimento sobre o negócio do "Instituto A" pelas demais áreas e isto traz implicações práticas para a performance da rotina (FELDMAN, 2003). 
O artefato chamado de "Ficha de Especificação de Material" ${ }^{21 "}$ é igual para qualquer material utilizado pela empresa, desconsiderando as características dos insumos químicos e de sua cadeia de fornecimento. Possivelmente haja uma dificuldade intrínseca da área de compras em comprar insumo químico com base neste artefato, podendo ser um ponto de partida para provocar a mudança ou adaptações nos padrões da rotina (FELDMAN, 2000).

Em relação ao alinhamento de interesses entre as áreas, verificou-se que pode haver espaço para formar rotinas a partir de sistemas generativos capazes de provocar outros tipos de performances (FELDMAN e PENTLAND, 2008). Existe uma necessidade de compras rápidas ou de quantidades menores que não justificam abrir um processo licitatório. Porém, a solução não é deixar a compra em espera até que forme o volume necessário à licitação, conforme posicionamento defendido pela área de compras. O comentário de um ator da área de compras aponta que "o tempo exíguo para a compra emergencial provoca a dificuldade, por não haver um processo formal instituído para este tipo de compra (entrevista C3)". Um comentário da área técnica, também ilustra a afirmação sobre a inadequação do aspecto ostensivo:

"Precisamos lembrar que o laboratório é um prestador de serviço[...] temos aquelas demandas esporádicas, que são necessidades de última hora para atender um cliente ou um contrato específico e pontual, para os quais nós precisamos ser ágeis para conseguir os insumos necessários.” (Entrevista T2)

A inexistência de tratamento adequado das compras emergenciais ou não programadas também foi apontada pela área de processos: "[...] tem que entender a angústia de quem está na ponta, de cara para o cliente"; ainda, comentou "área de compras é muito focada em compras de rotina, e não alinhada de fato com todo o plano estratégico, com suas ações e com seus projetos (entrevista $\mathrm{P} 1$ )", corroborando que há uma lacuna no aspecto ostensivo da rotina para atender este tipo de necessidade.

Por outro lado, ainda que o comentário da área de processos tenha sido o de que as "compras para projeto foram sempre atropeladas (entrevista P1)", apontou que não existe um envolvimento da área de compras durante a construção do projeto, mas apenas quando o planejamento do projeto está pronto, ou seja, "muito em cima da hora de comprar (entrevista P1)", isso se constitui uma contrapartida para a parceria necessária entre as áreas técnicas e de compras. Já que a rotina de compras é constituída de "ações

\footnotetext{
${ }^{21}$ É o artefato que mostra os detalhes e características do material a ser adquirido. É a grande referência utilizada pelos compradores.
} 
interdependentes desempenhadas por múltiplos atores", segundo Feldman (2003), é importante haver certa integração entre áreas, pois essa aderência está refletida no aspecto ostensivo da rotina organizacional que, por sua vez, pode ser ativada e restringida por vários artefatos (FELDMAN e PENTLAND, 2008).

A análise desta categoria demonstrou haver certos desacordos entre áreas e participantes. Pentland e Hærem (2015) apontam que os valores, normas e cultura são aspectos distintivos das organizações e nem sempre implicam em rotinas organizacionais, podendo ser, muitas vezes, incompatíveis com elas. Além disso, recomendam que a algumas orientações não podem ser seguidas de forma absoluta, justamente por serem situacionais, devendo haver uma adequação de acordo com o contexto, necessidade e interesses organizacionais. $O$ fato de haver múltiplos atores envolvidos na rotina organizacional não implica na duplicidade de papéis e falta de clareza sobre a responsabilidade (FELDMAN e PENTLAND, 2005), conforme apontado pela entrevista "[...] não existe uma matriz de responsabilidade clara [...] as funções se sobrepõem" (entrevista P1).

Portanto, os achados na categoria "Alinhamento de papéis, conceitos e interesses" ofereceram suporte que corrobora desalinhamento, provocando ou fomentando a variação na performance da rotina. Parte do papel da área de compras é desempenhado, à medida que foca no cumprimento das regras para comprar e desconsidera o compromisso de parceria com seu cliente interno, o "Instituto A". Para cumprir o papel de atender o cliente externo, a área técnica precisa incorporar a competência da compra de insumos químicos. O conceito da compra de insumos químicos está nebuloso dentro da própria área de compras, principalmente com base no discurso dos atores estratégicos, os quais norteiam o trabalho das equipes. O aspecto ostensivo da rotina de compras está focado no cumprimento da regulamentação interna de compras, desconsiderando o interesse da área técnica nas compras emergenciais para atender os clientes, muito embora possa haver um desconhecimento da área de compras sobre essa necessidade, uma vez que não foi observada a atitude de parceria mútua entre as áreas de compras e a técnica. O Quadro 4 resume as divergências entre os entendimentos das áreas e os resultados da análise desta categoria. 
Quadro 2: Resumo de entendimentos e resultados

\begin{tabular}{|l|l|l|}
\hline \multicolumn{1}{|c|}{\begin{tabular}{c} 
Entendimentos sobre $\begin{array}{c}\text { alinhamento de papeis, } \\
\text { conceitos e interesses }\end{array}$ \\
\cline { 2 - 3 } Papel da área de compra
\end{tabular}} & \multicolumn{1}{|c|}{ Área de Compras } & \multicolumn{1}{c|}{ Área Técnica } \\
\hline Defender a empresa nas auditorias & $\begin{array}{l}\text { Deveria ser de parceria, o que seria estratégico } \\
\text { para a área técnica. Mas, não há como } \\
\text { depender da área de compras }\end{array}$ \\
\hline $\begin{array}{l}\text { Conceito de compra de } \\
\text { insumos químicos }\end{array}$ & $\begin{array}{l}\text { Atores estratégicos consideram indiferente da } \\
\text { compra de outros insumos } \\
\text { Atores táticos e operacionais consideram } \\
\text { específico e difícil }\end{array}$ & $\begin{array}{l}\text { Especifica, difícil, peculiar e totalmente diferente } \\
\text { de qualquer compra da empresa }\end{array}$ \\
\hline $\begin{array}{l}\text { Interesses das áreas em } \\
\text { relaçäo à compra de insumos } \\
\text { quimicos }\end{array}$ & $\begin{array}{l}\text { Cumprir os requisitos legais da compra é a } \\
\text { prioridade }\end{array}$ & $\begin{array}{l}\text { Ter processos ágeis que garantam o suprimento } \\
\text { para projetos urgentes é a prioridade }\end{array}$ \\
\hline $\begin{array}{l}\text { Rotinas Organizacionais de } \\
\text { compras }\end{array}$ & $\begin{array}{l}\text { Adequadas para manter os controles para a } \\
\text { auditoria }\end{array}$ & $\begin{array}{l}\text { Ineficientes, engessadas e não prevêm a } \\
\text { necessidade da área técnica }\end{array}$ \\
\hline
\end{tabular}

Fonte: Elaborado pela pesquisadora com base nas narrativas e análise documental

\section{2.}

\section{Estruturação das rotinas organizacionais}

Esta categoria buscou analisar como a rotina de compra de insumos químicos está estruturada para atender os interesses e necessidades dos clientes internos e externos, considerando o aspecto ostensivo, o aspecto performativo e os artefatos. Para obter a explicação da dinâmica que ocorre em uma rotina específica é necessário "desempacotar" suas partes, abrindo a "caixa preta" e verificando cada uma delas em separado (FELDMAN e PENTLAND, 2005; D'ADDERIO, 2008).

\section{FOCO NO OSTENSIVO}

Como o aspecto ostensivo guia as pessoas, explica e se refere às performances específicas da rotina, nesta pesquisa, ele foi investigado a partir das narrativas que os entrevistados da área de compras passaram sobre a ideia geral da rotina que fundamenta a realização do trabalho, da forma como ela está estruturada e deveria acontecer (FELDMAN, 2003; PENTLAND e FELDMAN, 2005; COHEN et al., 1996; CYERT e MARCH, 1963). De forma geral a rotina de compras é composta por sete etapas, descritas a seguir, cujos padrões são reconhecíveis e se desdobram para algumas tarefas realizadas por múltiplos atores (FELDMAN e PENTLAND, 2003; PENTLAND e H/EREM, 2015). O detalhe sobre o aspecto ostensivo da rotina de compras está apresentado no ANEXO A deste documento. 
O grande desafio foi encontrar o "fio da meada", pois, cada participante deu sua visão sobre as rotinas (PENTLAND e FELDMAN, 2008). Nem sempre as etapas apresentaram clareza sobre a interdependência e alguns depoimentos deixaram claros que os atores não possuem a visão global das rotinas, bem como o entendimento da importância das etapas do processo, evidenciando a teoria de Cohen (2007), que salienta as rotinas inúteis, citando aquelas que são estabelecidas, muitas vezes, por pessoas que não a desempenham.

Foi observado controvérsias entre os atores sobre os aspectos ostensivos, não ficando claro se estão bem fundamentados ou se a divergência de discurso está ligada ao entendimento que cada ator tem sobre a rotina (PENTLAND e FELDMAN, 2005). Os comentários abaixo reiteram este problema:

[...] a área de compras deve fazer as cotações para efetivar a compra e a área técnica deve fazer a cotação apenas para a evidência de preço. São duas coisas completamente diferentes; [...] há uma confusão mental da área solicitante que enxerga os três preços já como uma cotação de preço...cotar preço é o trabalho do comprador, senão eu não preciso dele. [...] se a área técnica não fizer as cotações, a compradora vai precisar de pelo menos uma semana a dez dias para fazer a cotação...não por ela ser lenta, mas o mercado demora [...] a gente está discutindo com auditoria agora, tentando criar uma linha de corte, onde pelo menos, até determinado valor, a área requisitante mande apenas uma evidência de preço, não precisa mandar três [...]. (Entrevista C1)

Eles (área de compras) pedem uma cotação, que é a chamada evidência de preço, mas a gente manda as três para agilizar o processo... não sei pra que a gente precisa fazer a evidência de preços. Eles também poderiam fazer [...]. (Entrevista T6)

A equipe técnica tem que passar uma evidência de preço [...] em cima dessa mesma evidência de preço nós fazemos a cotação e mandamos a solicitação para o mesmo fornecedor"; "a evidência de preço tem que vir assinada, então o fornecedor escaneia e manda [...] mas não sei informar o motivo desse procedimento, só sei que deve ser cumprido. (Entrevista C7)

Além de fazer todo o levantamento da quantidade suficiente do estoque, nós temos que buscar evidências de preços no mercado... até então nós precisávamos buscar uma evidência, a partir de agora do mês passado nós temos que usar três evidências para passar para a área de compras [...]. (Entrevista C4)

[...] para comprar qualquer valor eu preciso, pelo menos, cotar três preços no mercado. (Entrevista C2)

[...] no afã do processo ser realizado mais rápido, a área técnica faz as três cotações [...]. (Entrevista C3)

Até 880 reais basta mandar uma evidência de preços só, acima desse valor tem que mandar três [...]. (Entrevista T2)

Eles (área de compras) informaram que o TCU exige três cotações assinadas, carimbadas e datadas pelo fornecedor. (Entrevista P1) 
"A dificuldade em comprar os materiais químicos pode ser em função da Ficha de Especificação do Material estar desatualizada.” (Entrevista C5).

“[...] há falhas na distribuição das compras para os compradores, pois, às vezes as compras precisam ser feitas por uma mesma pessoa, porque elas estão interligadas, pelo mesmo fornecedor ou pelo mesmo tipo de produto [...]." (Entrevista C7)

O fato dos compradores não serem segmentados por tipo produto e terem perfil generalista pode dificultar a formação da competência para a compra de insumos químicos e o estabelecimento de relacionamento com o fornecedor. Alguns comentários denotam incoerências dentro da própria área de compras que podem motivar a variação na performance da rotina organizacional:

"Nossos compradores têm noções, muitas noções de materiais...se não conhecerem o material eles não seriam compradores...a ficha de especificação é só detalhe." (Entrevista C2)

"Nossos compradores compram para a empresa como um todo. Não há um comprador específico para cada segmento de produto ou unidade de negócios". (Entrevista C2)

Já tem o costume de comprar um determinado material...eles (compradores) já até sabem se a especificação do produto está correta ou não” e, ainda, “...quando o material nunca foi comprado, é o mercado que vai acusar qualquer erro ou inconsistência. (Entrevista C3)

"A ficha de produto não deixa clara as informações sobre o produto...onde vai ser utilizado, qual é o produto, com é manuseado, então a gente tem que buscar muitas informações para que não tenha erro"; "não sabemos se o material é perigoso, explosivo ou corrosivo. (Entrevista C7)

Outro aspecto observado no ostensivo, foi a citação de uma rotina ainda não formalizada na empresa a partir de estrutura e artefatos, que é o planejamento de compras. Ao iniciar as entrevistas com a área de compras, esta informou que a ausência de um planejamento para comprar insumos químicos é o grande gargalo, que justifica o fato de não conseguirem performar. Todos os atores da área de compras afirmaram que não há planejamento da área técnica para a compra de insumos químicos. Houve divergência de relato entre os entrevistados evidenciado pelos comentários a seguir:

"[...] eu afirmo para você com todas as letras maiúsculas, negritado e sublinhado que se houver planejamento, a compra funciona”. (Entrevista C2)

"Há dois anos nós da área de compras implantamos as visitas técnicas, que chamamos "O que vem por aí?". Elas servem para concentrarmos as demandas, abrindo os procedimentos de licitação" (Entrevista C2). 
"Se o "Instituto A" não tem planejamento ou não quer entrar em um procedimento licitatório, que é mais pesado, então eles compram para fugir disso. (Entrevista C2)

Ainda não notei diferença alguma com as visitas técnicas para planajemanto. Porque a maior parte das unidades alega que não tem como prever a demanda. (Entrevista C3)

"Desde o primeiro ano que ouvi a área de compras falar que não havia planejamento, em 2009, logo no início do ano enviamos. Em 2010 não era só enviar o planejamento, eu tinha que cadastrar tudo que eu comprasse por fora, no sistema, porque daí eles enxergariam e isso facilitaria." (Entrevista T1)

"Colocamos numa lista tudo aquilo que a gente precisa comprar. Acho que isso é uma forma de planejamento, mas eu acho que o fluxo acabou, vem outro". É necessário implantar metodologias capazes de prover o planejamento que independam de um indivíduo específico, pois quando depende do ser humano lembrar, não rola." (Entrevista T5).

É importante destacar que o planejamento considera apenas as compras realizadas pela área de compras em função de uma regra de sistema. As compras diretas, realizadas pela área técnica vão direto para o consumo do "Instituto A" e, portanto, ficam indisponíveis para o planejamento. Esta prática está fundamentada na teoria das "rotinas mortas" e sem sentido apontada por Cohen (2007). Os comentários a seguir iustram este descompasso no ostensivo:

"Bem mais da metade da necessidade de insumos do "Instituto A" não vai para o estoque (entrevista C5)”.

“Nos foi passado que, tudo o que é material estocável ${ }^{22}$, sempre terá no estoque. Só que os técnicos compram materiais estocáveis, mas este material não chega a passar pelo estoque. E porque não passa no estoque? Porque foi feita uma compra pela área técnica e não pela área de compras. E se não é feito pela área de compras, não tem rotatividade no estoque, e sem isso eles (área de compras) não conseguem ver a demanda que a gente gasta por mês e acabam não conseguindo comprar, porque dizem que não há planejamento. A gente tem este gap hoje e está difícil de resolver, porque os materiais estocáveis não são estocados. A partir do momento que eu entro com uma nota fiscal aqui no "contas a pagar" e eles entram com uma cópia no estoque, está entrando duas vezes aquele custo. Mas é um sistema gente! Tem que ter uma maneira de entrar. Eu quero poder comprar e pegar uma cópia da nota e dizer, gente eu preciso que isso aqui entre no estoque. Até hoje ninguém me deu uma solução. E acaba que, com a demanda, eu vou ser sincero, a gente só lembra quando tem algum problema." (Entrevista T3)

"Hoje a gente pode dizer, já demonstrado pela área de compras, que 89\% das compras são feitas pela equipe técnica, porque a gente não tem um armazém que tenha essa facilidade para que a gente possa estar retirando o material." (Entrevista T7)

\footnotetext{
22 Praticamente todos os insumos químicos utilizados pelo "Instituto A" são estocáveis. Alguns têm validade de 2 a 3 meses e esses, por uma questão de margem de segurança, não são considerados itens estocáveis.
} 
O planejamento como uma espécie de gatilho para a compra é apontado por Nelson e Winter (1982) como uma busca por resultados satisfatórios, muito embora algumas situações resultem em rotinas inapropriadas e requeiram customização (FELDMAN, 2003). Entretanto, a rotina de planejamento precisa ser melhor explorada e, para isso, é importante abrir sua "caixa preta", pois analisando apenas seus inputs e outputs sem considerar seu processamento, não é factível para conduzir ao nível de profundidade do conhecimento pretendido (PENTLAND e FELDMAN, 2005; 2008). Além disso, foi observado que não existe uma definição clara sobre o que é um item estocável e quais são eles. Atualmente, o que qualifica os itens que passarão pelo estoque é quem os comprou. $\mathrm{O}$ aspecto ostensivo da rotina é útil à medida que permite guiar a sua performance para gerar um resultado pretendido (FELDMAN, 2000). A abertura da SA é o mecanismo criado para apoiar o planejamento, mas ele não se aplica à maioria das necessidades de insumos do "Instituto A", uma vez que, segundo ator da área técnica:

\section{FOCO NOS ARTEFATOS}

O aspecto ostensivo é fundamentado em regulamentos de compra, uma norma, procedimentos, instruções operacionais e formulários, além do sistema, que adiciona um componente tecnológico sociomaterial à rotina que, segundo Leonardi et al. (2012), tem grande potencial transformativo, pois poucas pessoas contestam que as novas tecnologias trazem mudanças na forma de comunicação, ação e organização (D'ADDERIO, 2011). A lista dos artefatos utilizados está apresentada no APÊNDICE A deste documento, apesar de que a presença de artefatos não garante a existência de uma rotina organizacional estruturada e funcional (PENTLAND e FELDMAN, 2005), já que podem estar ambíguos ou desatualizados.

Foi observado durante as entrevistas que alguns artefatos estão desatualizados ou carecem de ajustes. É o caso da ficha de especificação de produtos, do módulo do sistema e da rotina de planejamento, que não está formalizada. Os comentários a seguir evidenciam essas questões:

\footnotetext{
"A especificação do material é a alma do negócio... e se estiver malfeita faz com que a gente ou compre mal ou compre errado. As informações colocadas na ficha são "pífias" ou sequer informam alguma coisa...são um problema sério, muito sério" [...] Este artefato é satisfatório para a realização da compra, pois foi melhorado recentemente." (Entrevista C1)
} 
"Desconheço qualquer melhoria ou incremento na Ficha de Especificação de Material. A versão oficial é bem limitada e não apresenta uma data de validade ou processo de revisão. Podemos ter uma biblioteca de lixo dentro do sistema." (Entrevista P1)

"Foi identificado que a construção do processo de planejamento na área de compras é um ponto a melhorar.” (Entrevista P1)

Tão importante quanto atualizar as informações sobre os insumos químicos, é incrementar o artefato Ficha de Especificação de Materiais para que ele seja útil para os compradores, pois os artefatos incompletos, desatualizados ou ambíguos não apontam a lógica que guia a ação, além de serem considerados rígidos como "rotinas mortas" (FELDMAN e PENTLAND, 2008; COHEN, 2007).

Outro agravante que propicia duplicidade nos cadastros de materiais e a desatualização constante do sistema é que cada unidade de medida de insumo deve ser cadastrada como se fosse um novo material. Porém, as embalagens dos fornecedores variam muito, principalmente para os insumos importados de vários países. Por exemplo, álcool 99\% 250 ml, álcool 99\% 500 ml, álcool 99\% $1000 \mathrm{ml}$ e álcool 99\% 1L, são quatro $\mathrm{SKUs}^{23}$ diferentes, ainda que os dois últimos constituam a mesma medida. O sistema faz o cálculo automático das compras a partir das unidades cadastradas e do preço da cotação. O mecanismo criado para dar agilidade ao sistema traz uma consequência negativa para os compradores, que precisam fazer uma conversão de medidas, denotando inadequação do uso da tecnologia para ações que deveriam acontecer de forma mais precisa, rápida e efetiva (LEONARDI et al, 2012; D'ADDERIO, 2011). A correta parametrização de sistemas requer a análise apurada das ações de causa e consequência.

“Um dia desses eu peguei um reagente de 24 mil e o produto custava $R \$ 192$. É porque a gente coloca a quantidade que a gente quer e o próprio sistema calcula o valor. Se eu coloco em $\mathrm{Kg}$ e o produto está cadastrado em grama no sistema ele vai fazer o cálculo pelo valor das gramas e não do Kg que eu estou comprando." (Entrevista C8)

${ }^{23}$ Stock Keeping Unit (SKU), em português Unidade de Manutenção de Estoque, é definido como um identificador único de um produto e é utilizado para manutenção de estoque (BAILY et al, 2000). 
Outro aspecto observado foi a quantidade de processos manuais e elementos tangíveis, com uso de carimbos e validações físicas, desconsiderando o papel do sistema como um ator não humano, pois um conjunto estável de atores é desnecessário já que os sistemas de fluxo de trabalho informatizados podem incorporar algumas etapas do processo (PENTLAND e H/EREM, 2015). Leonardi et al. (2012) aponta a importância do uso do componente tecnológico como mecanismo capaz de provocar mudanças organizacionais e facilitar o processamento das rotinas. O dossiê físico de cada processo de compras deve ser montado conforme o padrão apresentado na Figura 9.

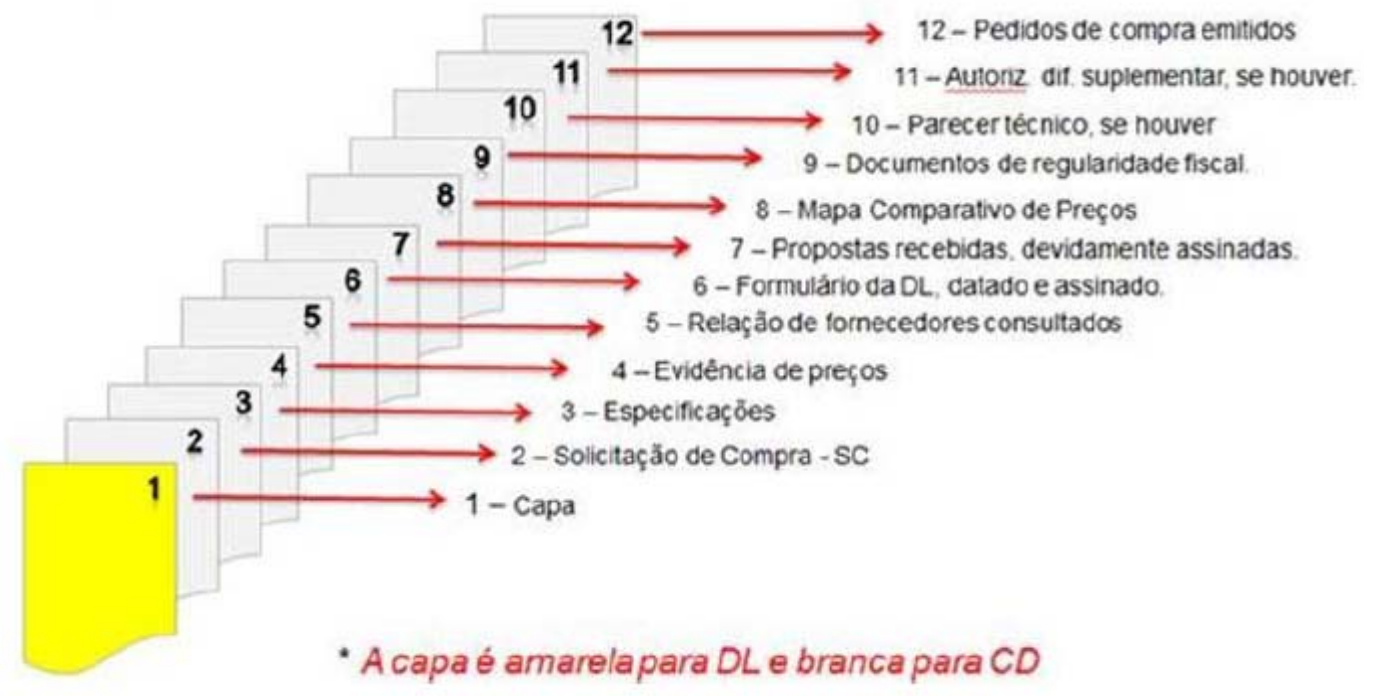

Figura 9: Modelo de Organização dos Processos

Fonte: Artefato “Efetuar compra”.

\section{FOCO NO PERFORMATIVO}

Nem todas as performances da rotina de compras foram observadas por não ter sido permitido pelos gestores. Além disso, é difícil afirmar que todas as ações ficaram visíveis, pois algumas podem ser menos evidentes (FELDMAN e PENTLAND, 2008). Contudo, a observação das performances pela área técnica, embora não exaustiva, possibilitou a comparação dos aspectos ostensivo e performativo (REAGIN, 1987 apud FELDMAN e PENTLAND, 2008). Quando foi questionado aos funcionários da área técnica como eles haviam aprendido a comprar, responderam que, frente a uma grande confusão de procedimentos, a performance foi baseada na memória de procedimento e transacional de técnicos experientes, cujo processo paralelo de compras foi fundado na pressão para a consistência das ações (MILLER et al., 2012; TURNER e RINOVA, 2012). Nem sempre as etapas da rotina acontecem, constituindo uma variação que 
indica que nem sempre a estrutura organizacional está apta a dominar os fragmentos da rotina (DOSI, NELSON e WINTER, 2000).

Segundo Feldman \& Pentland (2003), aspecto performativo cria, mantém e modifica o aspecto ostensivo da rotina. Neste sentido, na comparação das ações de compra pela área técnica com as narrativas do ostensivo pela área de compras, foram observadas algumas variações, que deram origem a resultados diferentes, alterando a qualidade da ação (FELDMAN e PENTLAND, 2008; D'ADDERIO 2008). Tentou-se observar as mesmas etapas identificadas no aspecto ostensivo (WHITE, 1992 apud FELDMAN e PENTLAND, 2008), embora a área técnica realize a performance a partir de uma sequência diferente aquela apontada no ostensivo, invertendo alguns processos. Ainda assim, a área de compras solicita que as etapas sejam respeitadas, principalmente em função dos parâmetros do sistema:

O nosso processo de compra paralelo é ágil porque a gente solicita os produtos numa lista de compras, o chefe aprova rápido, o técnico já fez as 3 cotações e já envia tudo para o administrativo, que trabalha para que o pedido seja emitido em uma semana [...] o administrativo pega esta aprovação junto com as cotações e é visto o menor preço, abre um pedido de compras, que vai automaticamente para o nosso técnico, que liga para o fornecedor do menor para agilizar a entrega assim que ele receber o pedido de compras. Às vezes a entrega é com 30 dias e ele pergunta se tem como entregar com 20 ou 15 dias, se tem como agilizar. Isso é o que acontece hoje, e talvez seria o que eles tivessem que fazer, mas a gente acaba tendo que fazer diretamente. Depois esse processo vai para a área de compras fazer o processo normal, mas a compra já foi realizada. (Entrevista T6)

"É solicitada uma autorização para o gerente para fazermos uma compra por fora, mesmo depois de eu ter solicitado ao armazém (entrevista T8)".

"A solicitação do produto ao estoque é fundamental mesmo que não haja produtos lá. Alguns produtos não são estocados e o sistema avisa neste momento [...] as duas portas de entrada de materiais para as áreas são através do estoque ou da compra. A tratativa do estoque é do setor de planejamento e a tratativa da compra é do setor de compras [...]". (Entrevista C5)

"Eu recebo várias solicitações de materiais do estoque, mas não tenho como atender, pois não há itens lá. Essas solicitações ficam pendentes, mas não causam nenhum impacto, apesar de que se acumular muito é ruim. O material que chega aqui eu já baixo direto e entrego aos técnicos.” (Entrevista C6)

A área de compras não provoca a mudança necessária nas rotinas de compra para os insumos químicos, seja pela falta de entendimento de como a área técnica opera ou pelo foco exclusivo no cumprimento do regulamento, ou outro motivo. Porém, impelida pela performance fundamental para a sua operação, a área técnica criou uma nova performance, mais ágil, as quais poderão guiar novas performances para a própria área de compras (FELDMAN, 
2003). O comentário de um ator da área de compras ilustra alguns resultados da diferença entre performances. Outro comentário de um ator da área técnica, levanta a questão sobre uma investigação mais profunda que se faz necessária nesta performance e pode indicar a pressão dos participantes para tentar manter o equilíbrio e a consistência da rotina, mesmo com as mudanças de padrão (TURNER e RINOVA, 2012).

Nessas compras emergenciais feitas pela equipe técnica eu não tenho certeza que precisa de três orçamentos [...] porque eles compram tão rápido [...] Eu não consigo entender. Eles mesmos aqui ficam cobrando a gente, porque eles compram toda hora. Acredito que eles têm um limite para comprar devido à emergência, $e$ às vezes eles podem comprar um pouquinho fora do preço. Mais caro, só pode ser, porque vem mais rápido. O pessoal entrega rapidinho, isso acontece, fornecedores entregam rápido. Agora, eu não sei por que a área de compras não tem esses fornecedores, isso eu não sei dizer, porque é que eles não conseguem. (Entrevista C6)

O cara que está lá na ponta usando o material diz: Caramba, esqueci de comprar! Então sai correndo pra comprar, entendeu? E já faz as cotações para adiantar o processo [...] vejo que o setor de compras poderia ajudar muito e não ajuda da forma que a gente necessita. (Entrevista T5)

Um dos motivos da compra sair tão rápida quando é performada pela área técnica é pelo fato deles terem desenvolvido um banco de fornecedores que respondem rapidamente às cotações. Como eles estão habituados a comprar, já sabem o preço médio dos insumos, as marcas confiáveis, julgando de forma bastante precisa quando um preço está fora das práticas do mercado. Como os compradores são generalistas e não segmentados por materiais, eles desconhecem os detalhes da compra, além de não estabelecerem uma relação com os fornecedores, conforme denotado no comentário a seguir.

Às vezes o fornecedor também responde com uma marca diferente daquela que estamos solicitando, aí pedimos para ele refazer ou responder expressamente que não tem e por isso está mandando aquela outra marca. Precisamos fazer as compras com as marcas homologadas (entrevista C7).

A falta da rotina de qualificação de fornecedores e por não haver compradores especializados em um segmento de compra pode estar dificultando a performance da rotina pela área de compras, pois, além de não sugerir uma referência (SIMON, 1997), falta uma coordenação de ações que promovem a eficiência estrutural dentro do contexto da compra (COHEN; BACDAYAN, 1994). 
Depois da área técnica ter assumido a responsabilidade pela maioria das compras, os técnicos passaram a utilizar seu conhecimento tácito para a compra de insumos, a partir do uso da habilidade individual (MILLER et al., 2012). Dessa forma, as "Fichas de Especificação de Material" passaram a ficar cada vez mais desatualizadas, provocando a obsolescência de grande parte do cadastro de materiais de produtos químicos e deteriorando a atuação da área de compras. Nesse sentido, as áreas de compras e técnica acordaram entre si fazerem uma varredura no sistema para a atualização de cadastros. Feldman e Pentland (2005) afirmam que as atividades, tarefas e hábitos individuais não fazem parte do conceito de rotinas. É necessário que essa ação seja contínua, padronizada e interdependente.

Foi observada que a comunicação da compradora com o fornecedor é bastante formal, em geral baseada em e-mail, diferente da comunicação do técnico, que embora educado, denotava um tratamento mais "personalizado e próximo" ao fornecedor. Além disso, houve dúvida em relação ao material solicitado. O sistema não provê o registro de ações dos usuários oriundas do aspecto performativo da rotina, que constituiriam os artefatos oriundos desta performance, refletindo a ausência da criação de entendimento sobre a performance da rotina organizacional (FELDMAN, 2003):

O sistema que me apoia é o ERP que não tem um campo onde a gente possa anotar nada. Eu nem posso inserir nada, pois isso é da área de cadastro. Se eu tiver alguma observação eu tenho que falar para eles.(Entrevista C8)

É importante salientar que não há aspecto ostensivo fundamentado para o acompanhamento do pedido, desde a expedição no fornecedor, até sua entrega na empresa. Os técnicos realizam esta performance, pois têm total interesse no recebimento da mercadoria o que sugere a necessidade de ostensivo e artefatos capazes de apontar esse "enquadramento" para as ações (D'ADDERIO, 2008). Então, assim que a compra é aprovada, os técnicos entram em contato com o fornecedor avisando que entrará um pedido para ele poder agilizar ou até negociam uma entrega mais rápida, dependendo da necessidade. Esta é a performance de acompanhamento do pedido, que não está prevista no ostensivo, mas é performada pela área técnica e se trata de mais uma forma da compra chegar mais rápido. A qualidade da execução dessas etapas da rotina varia de acordo com a subjetividade do participante e suas experiências, podendo provocar uma evolução nas rotinas (FELDMAN e PENTLAND, 2003). 
Quando a gente coloca o pedido no fornecedor a gente passa um call center para a área técnica, para eles entrarem em contato com o fornecedor, caso o produto demore. A gente não monitora a movimentação do pedido após deixá-lo no fornecedor. A gente só comunica a área técnica para eles fazerem isso, informando o prazo de entrega. Se passou do prazo de entrega eles têm que ligar para o fornecedor para ele verificar o que houve, ou até entra em contato com a gente, que a gente entra em contato com o fornecedor. (Entrevista C8)

Sobre o planejamento de compras, a área de compras insiste que não existe este planejamento e a área técnica aponta que encaminha uma lista de itens a serem adquiridos a cada 6 meses:

"O problema é que o ponto de equilíbrio se perdeu, e aí se inverteu o processo de compras". (Entrevista C1)

Eu não sei te dizer se a pessoa que está falando em planejamento, se ela recebeu, se ela esqueceu ou se foi pra outro lado. Tem algum boi na linha aí. Estamos nos planejando, nós enviamos e temos a evidência disso. Aí chegam no próximo ano e dizem que eu não planejei. Então tem alguma coisa estranha aí nesse processo, que este planejamento some. Se esse planejamento que a gente fez chegou nas mãos da pessoa responsável, e se esta mesma pessoa não tem um processo de planejamento formalizado, o que garante que ele vai identificar aquilo que eu mandei é o planejamento. Pode ser que o que eu mande eles não considerem que é um planejamento, a outra unidade manda e eles também não consideram. Então, ninguém planeja. Tem um buraco negro nessa história!” (Entrevista T1)

Para o planejamento existir de fato, nós precisamos estabelecer metodologias que não dependam de uma pessoa responsável, que seja uma coisa do grupo, para que isso funcione. Porque, hoje, eu acho que os processos estão muito dependentes da pessoa. E aí, se essa pessoa falta nada funciona. Acho que não basta ter um back up de outra pessoa, deve ser institucional. Tem que ser uma coisa que diga que o "Instituto A" funciona assim, independente da pessoa. Aqui o fluxo é este, muito dependente da pessoa. Tanto é que se a gente fizer análises por laboratório, é possível que a gente tenha resultados completamente diferentes. Um laboratório é muito otimizado no planejamento, outro nem tanto. Isso reflete o que? É a pessoa e não a organização.(Entrevista T5)

Segundo Feldman e Pentland (2003) o contexto organizacional é amplo e o poder e a subjetividade dos sujeitos guia inúmeras performances, as quais não foram exaustivamente observadas nesta pesquisa, já que a observação das ações é limitada a pequenos períodos e está distribuída no espaço, entre os participantes, além de ser onerosa por requerer disponibilidade de tempo para as observações (FELDMAN e PENTLAND, 2008). Portanto, sugere-se a abertura de agenda de pesquisa futura para fechar esta lacuna e explorar mais a questão do poder, da subjetividade e da agência preconizada pela perspectiva prática da rotina organizacional (FELDMAN E PENTLAND, 2003; PARMIGIANI et al., 2011; EMIRBAYER e MISCHE, 1998). Por outro lado, a estabilidade das rotinas se justifica pelo esforço consciente das áreas de compras e técnica em manter o 
foco no cumprimento da regulamentação, considerando que a compra deva ocorrer dentro dos padrões (CYERT e MARCH, 1963; SIMON, 1957; FELDMAN, 2000; FELDMAN, 2003, 2004; FELDMAN e PENTLAND, 2003).

A memória de procedimento defendida por Cohen e Bacdayan (1994) pode ser verificada na performance das rotinas de compra pela área técnica, pois os sujeitos usaram seu conhecimento tácito para fazer as compras de insumos químicos. Porém, Miller et al. (2012) defendem que a criação das rotinas acontece a partir da dinâmica entre a ação e a memória. Os autores apontam os tipos de memória utilizada pela área técnica para a construção das novas performances, entendendo o que deve ser feito (cotação, abertura de SC) e quem poderá apoiar (área administrativa, área de compras, fornecedores). Porém, a memória sequencial da rotina foi totalmente invertida, pois não há como performar a compra dentro de um prazo exíguo, a partir da sequência do aspecto ostensivo da rotina de compras (MILLER et al., 2012).

O Quadro 5 a seguir apresenta os atributos diferenciados em relação à performance da rotina de compras realizadas por ambas as equipes e cada qual implicou em um resultado diferente.

Quadro 5: Comparação entre as Rotinas Organizacionais

\begin{tabular}{|c|c|c|}
\hline \multirow{2}{*}{ Critérios } & \multicolumn{2}{|c|}{ Performance da Rotina Organizacional } \\
\hline & Área de Compras & Área Técnica \\
\hline Comunicação & $\begin{array}{l}\text { Formal e restrita entre os compradores, } \\
\text { as pessoas do cadastro, os técnicos, em geral por e- } \\
\text { mail. }\end{array}$ & $\begin{array}{l}\text { Ampliada entre os técnicos, os administrativos que } \\
\text { abrem a solicitação de compras via sistema ERP, os } \\
\text { aprovadores da compra. }\end{array}$ \\
\hline $\begin{array}{l}\text { Tamanho da } \\
\text { compra }\end{array}$ & $\begin{array}{l}\text { Precisam aguardar o fechamento de lotes maiores } \\
\text { para serem licitadas. }\end{array}$ & Compra de pequenos lotes de materiais. \\
\hline $\begin{array}{l}\text { № de pessoas } \\
\text { performando }\end{array}$ & $\begin{array}{l}\text { Um comprador faz as cotações dos insumos e todo o } \\
\text { processo burocrático do dossiê. }\end{array}$ & $\begin{array}{l}\text { Vários técnicos fazem as cotações e salvam na rede. } \\
\text { O administrativo lança as SCs com as cotações. }\end{array}$ \\
\hline $\begin{array}{l}\text { Competências } \\
\text { técnicas }\end{array}$ & $\begin{array}{l}\text { Formação gereralista, precisa de grande apoio da } \\
\text { Ficha de Especificação de Material. }\end{array}$ & $\begin{array}{l}\text { Formação especifica em Química (Técnica ou } \\
\text { Superior). }\end{array}$ \\
\hline $\begin{array}{c}\text { Banco de } \\
\text { Fornecedores }\end{array}$ & $\begin{array}{l}\text { Desconhecem o banco de fornecedores e precisam } \\
\text { buscar alguns na internet. }\end{array}$ & $\begin{array}{l}\text { Desenvolveram relacionamento com os fornecedores, } \\
\text { que enviam as cotações rapidamente. }\end{array}$ \\
\hline \multirow{2}{*}{$\begin{array}{l}\text { Processo de } \\
\text { Compras }\end{array}$} & $\begin{array}{l}\text { Montam um dossiê físico do processo de compras e } \\
\text { outro digital através do sistema ERP. }\end{array}$ & Submetem documentos digitais para o sistema ERP. \\
\hline & $\begin{array}{l}\text { A análise da proposta do fornecedor é lenta, pois às } \\
\text { vezes o aprovador da área técnica desconhece o } \\
\text { fornecedor, a marca. }\end{array}$ & $\begin{array}{l}\text { Análise da proposta do fornecedor e emissão de } \\
\text { parecer, caso não se escolha o menor preço, é rápida } \\
\text { pois os técnicos já sabem de quem e por quanto } \\
\text { comprar. }\end{array}$ \\
\hline
\end{tabular}

Fonte: Elaborado pela pesquisadora com base nas observações de campo. 
Sendo assim, em relação à categoria "Estruturação das Rotinas Organizacionais" é possível verificar alguns pontos que motivam a variação da performance. A natureza das rotinas de compras de insumos químicos requer uma dinâmica flexível em função das suas peculiaridades (pequenas quantidades, materiais específicos, compra expressa). Nesse sentido, alguns aspectos ostensivos não refletem suas performances e não estão refletidos nos seus artefatos, que podem exigir padrões de ação mais rígidos para poderem funcionar melhor (COHEN, 2007). Portanto, sempre que surge a imperiosa necessidade por insumos, o aspecto ostensivo é desprezado pelo performante, pois, segui-lo não permite o atendimento ao cliente.

Da mesma forma, aspectos ostensivos ambíguos também podem estar causando a variação da rotina durante sua performance, além da falta de definição clara da matriz de responsabilidade da área de compras por algumas tarefas, bem como do processo de interdependência de ações para prover a "passagem de bastão" para a próxima tarefa. Ainda, alguns artefatos não estão totalmente adequados para apoiar a performance da rotina organizacional. $O$ setor responsável dentro da área de compras não realiza ações periódicas de atualização dos artefatos, a partir de uma rotina padronizada com relação de interdependência com múltiplos atores performando (FELDMAN, 2000).

Os problemas no aspecto ostensivo ou artefatos da rotina de compras não são reconhecidos por alguns atores estratégicos da área de compras, os quais julgam que a ausência do planejamento é a grande impedidora da performance da compra. Contudo, a rotina organizacional de planejamento não possui aspecto ostensivo claro e totalmente definido, muito embora seja fundamental e considerada um fator crítico para o sucesso da compra. E a impossibilidade de colocar todas as compras de insumos químicos em uma grande licitação pode estar sendo caracterizada de "falta de planejamento da área técnica", o que abre uma agenda de pesquisa futura.

Outro ponto que motiva a variação é que o cumprimento do regulamento e norma de compras é mutuamente excludente ao cumprimento dos prazos de compra, uma vez que o processo foi formatado para compra em grandes quantidades e com o prazo dilatado. A área de compras não possui tratamento específico para as compras emergenciais, de pequenos lotes, não planejadas. 
Também, a burocracia extrema e desnecessária à rotina organizacional de compras atrasa o processo, deixando-o manual e burocrático. O sistema utilizado para apoiar a rotina de compras deve ser melhor ajustado para prover sua agilidade e desburocratização do processo, devendo prover o registro da performance das ações, pois boa parte do conhecimento da rotina está sendo perdida pela empresa e são informações que constituiriam artefatos importantes.

Os compradores não são segmentados por tipo de compra, prejudicando seu relacionamento com os fornecedores, cujo banco não está qualificado pela área de compras.

\section{3.}

\section{Relação entre os aspectos ostensivo, performativo e artefatos}

Esta categoria buscou analisar se existe relação entre os aspectos ostensivo, performativo e artefatos dentro do contexto da rotina de compras de insumos químicos, pois é importante que haja entendimento da inter-relação complexa que há entre os aspectos da rotina e entre cada aspecto com os artefatos existentes na empresa (PENTLAND e FELDMAN, 2005; D'ADDERIO, 2008). As rotinas são importantes à medida que promovem a variedade de habilidades e inabilidades da empresa se adaptar aos contextos e situações de mudança (PENTLAND e RUETER, 1994; FELDMAN e RAFAELI, 2002), gerando mudanças, meramente por seu desempenho (FELDMAN e PENTLAND, 2003). Sendo assim, esta categoria buscou referência sobre os mecanismos que podem provocar a mudança endógena ou a estabilidade, uma vez que o potencial da rotina como um recurso de mudança só pode ser entendido através dessa interação, a partir das informações imprescindíveis que pode ela oferecer (PENTLAND e FELDMAN, 2003; FELDMAN, 2005; FELDMAN E PENTLAND, 2008). Entretanto, Feldman e Pentland (2008) apontam a complexidade da rotina e o cuidado metodológico que deve ser utilizado ao investigá-la, contudo ao utilizar a rede de narrativas e observações para identificar as interfaces entre as partes da rotina (FELDMAN e PENTLAND, 2008; HANNANA e FREEMAN, 1983; D'ADDERIO, 2008). 
Verificou-se que os aspectos ostensivos das rotinas organizacionais abordadas nesta pesquisa possuem uma estrutura baseada no cumprimento de regulamentos necessários à proteção organizacional e os artefatos foram ajustados para este fim (GIDDENS, 1984), aplicando-se apenas a interações individuais em vez de apoiarem as interações coletivas do sistema generativo das rotinas, causando a desconexão entre metas e resultados (PENTLAND e FELDMAN, 2008). O desalinhamento entre as necessidades de áreas dificulta a gestão e o trabalho (PENTLAND e FELDMAN, 2005). Sendo assim, há uma desconsideração da rotina organizacional de compras como um sistema generativo fundamentado em um processo que envolve a coordenação de múltiplos atores (PENTLAND et al., 2012). Esta realidade encontra apoio na teoria ao se observar que as ações das rotinas estão dispostas em silos, constituídos por áreas, sem uma coordenação entre as atividades performadas por cada área (PENTLAND e FELDMAN, 2008). As rotinas não estão totalmente interconectadas, embora algumas delas tenham relação de interdependência, onde uma ação deveria apoiar outra ação. Os depoimentos a seguir ilustram que a relação entre as partes da rotina não obedece uma dinâmica necessária para a geração da mudança:

"Essa ficha de produto não é dinâmica, não é atualizada, não tem mudança, pois a equipe de compras não tem capacidade técnica para fazer a atualização e a gente tem que fazer a toda hora uma ficha de produto para algum produto que já está cadastrado, mas com uma outra especificação.” (Entrevista T6)

"Quando entra um produto novo para eu comprar eu entro na internet para pesquisar alguns fornecedores, pois não sei quem pode fornecer. Esta á a prática adotada pela área de compras para conseguir fornecedores”. (Entrevista C7)

"Buscar fornecedores de insumos químicos pela internet é a prova real de que a área de compras não está preparada para comprar esse tipo de produto. É necessário entender essa cadeia de suprimentos, sua pecualiridades. Nem todos os fornecedores bons estão na internet." (Entrevista T2).

Além disso, é importante relatar que existe variação entre os artefatos e a performance, uma vez que novas ações, adaptações, atalhos e improvisações foram acrescentados à rotina de compras pela área técnica, com o intuito de cumprir os prazos de compra, atendendo a necessidade de suprimentos e insumos químicos para a operação do "Instituto A", dentro dos preceitos legais (PENTLAND e FELDMAN, 2005). Porém, não houve a devida atualização dos artefatos, que permaneceram estáveis e não mais servem para apoiar algumas performances da área de compras. Ademais, algumas especificações são difíceis de descrever no artefato, principalmente quando se trata de uma 
especificação técnica de um insumo químico. A narrativa abaixo ilustra esse caso:

"Quando eu começo a falar em uma molécula química complexa, com grau de pureza específico, com volumes diferenciados, com classificações que podem ou não ser padrão, isso já dá ao componente um nome e sobrenome, que cria uma situação difícil inclusive de amarrar no ERP... por exemplo, clorofórmio, que aparentemente é uma coisa simples, não é uma palavra tão difícil...ou estranha...é uma substância controlada...preciso ter licença...preciso definir o grau de pureza...preciso te dizer qual é o volume que eu vou comprar...preciso informar se aquilo é um padrão de referência ou não, às vezes preciso definir inclusive a forma da embalagem. Se for um padrão eu posso querer em ampolas ou em frascos, ou eu posso querer em outra apresentação específica ou dissolvido em um outro solvente, por exemplo, uma substância de clorofórmio diluída em tolueno [...]". (Entrevista T2)

Por último, verifica-se, também, um desalinhamento entre os aspectos ostensivo e performativo, pois a rotina foi invertida para poder atender as necessidades de cumprimento de prazos. A declaração do ator de compras reitera a inversão do processo:

Ao certo, o processo seria, o técnico do "Instituto A" emitir a Solicitação de Compra com uma evidência de preço e o setor de compras entrar em contato com outros fornecedores, diferentes desse que foi utilizado para a evidência de preço, pois a gente tem que ter pelo menos três preços, para poder finalizar o processo com o preço mais barato. Só que o "Instituto A" faz o processo todo... o gerente dá o "de acordo" para iniciar o pedido de compras. O certo não seria esse. O certo seria o setor de compras fazer as pesquisas de mercado, para completar as três cotações e finalizar o pedido de compras[...] (Entrevista C8)

A performance da compra pela área técnica, desconsiderando o aspecto ostensivo da rotina, garante o atendimento das necessidades do "Instituto A". licitação de grandes volumes de compra nunca é realizado já que a característica do serviço aponta para a necessidade de processos de compra enxutos, com lotes menores. A variação do aspecto performativo se justifica pela falta de adequação no aspecto ostensivo; e a variação do ostensivo seria necessária, embora não aconteça, a fim de considerar o ajuste fundamental do processo para o atendimento das demandas urgentes (PENTLAND e FELDMAN, 2005). Um ator estratégico da área técnica comenta:

"É preciso entender melhor a característica da minha compra. Nem sempre comprar em quantidade é o que eu preciso. O descarte do insumo vencido custa caro e pode consumir toda a diferença favorável da compra em maior quantidade." (Entrevista T1) 
Portanto, o ostensivo não está restringindo o performativo, permitindo que a rotina de compras aconteça de forma invertida e essa variação conduz ao resultado desejado da compra dentro do prazo adequado para atender o cliente, o que é suportado pela teoria já que, ainda que haja uma estrutura ostensiva, a fonte de mudança está na agência do sujeito (FELDMAN, 2000; FELDMAN, 2003; D'ADDERIO, 2008). Embora Nelson e Winter (1982) considerem as rotinas como recursos capazes de mediar disputas, nesta situação, observa-se certo impasse e até mesmo conflito ocasional, uma vez que a área de compras insiste em realizar o processo de compras dentro dos padrões estabelecidos, apontando a ausência do planejamento como a grande responsável pela impossibilidade de comprar. Além disso, Rerup e Feldman (2011) consideram que elas podem reduzir a incerteza. Porém, é importante considerar, conforme as observações empíricas, que as rotinas atuais causam grande incerteza na área técnica, justamente por estarem desalinhadas das suas necessidades. Esses dois apontamentos, ou seja, mediação de disputas e redução da incerteza, constituem contrariedades aos preceitos teóricos, indicando que não basta ter uma rotina, mas ela deve estar alinhada às necessidades do contexto $e$ ser útil para o que se propõe (NELSON e WINTER, 1982; RERUP e FELDMAN, 2011). Por outro lado, o performativo recriou a rotina de acordo com as necessidades, que não foi aproveitada para alterar o ostensivo com a criação de um processo mais rápido e ágil para as compras emergenciais. Por sua vez, os artefatos não acompanharam os aspectos ostensivo e performativo, ficando defasados em relação ao contexto (HANNANA e FREEMAN, 1983; WEISS e ILGEN, 1986; GERSICK e HACKMAN, 1990; FELDMAN e PENTLAND, 2008).

O Quadro 6 apresenta um resumo sobre a relação entre os aspectos da rotina e seus artefatos. 
Quadro 6: Interações e Dinâmica das Relações

\begin{tabular}{|l|l|}
\hline \multicolumn{1}{|c|}{ Interaçóes } & \multicolumn{1}{c|}{ Resultado da Dinâmica das Relaçóes } \\
\hline Ostensivo-Performativo & $\begin{array}{l}\text { - Ostensivo permanece inflexível em função da insistência em realizar o processo a partir } \\
\text { de licitaçôes de compra de grandes lotes, desconsiderando as peculiaridade da compra de } \\
\text { químicos. Portanto, este aspecto não evolui de acordo com as melhorias do performativo, } \\
\text { não havendo mudança endógena da rotina organizacional, ainda que elementos exógenos } \\
\text { indiquem a necessidade da mudança. } \\
\text { - Performativo varia a partir das açốes da equipe técnica, com a inversão de algumas } \\
\text { etapas do ostensivo e o desempenho de ações que não estão suportadas por ele. }\end{array}$ \\
\hline Artefatos-Performativo & $\begin{array}{l}\text { - Performativo sofre adaptação e melhorias que não são incorporadas nos artefatos, pois o } \\
\text { sistema não é utilizado plenamente para favorecer a interface entre os participantes da } \\
\text { rotina organizacional. Há empoderamento da área técnica para a alteração da performance } \\
\text { justificada pela necessidade de atender o cliente. A área de compras não possui este } \\
\text { empoderamento, além de ter seu comportamento controlado pelos artefatos. } \\
\text { - Artefatos continuam estáticos, obsoletos e não mais apoiam algumas performances da } \\
\text { compra pela área de compras. Os participantes da rotina carecem de informações sobre a } \\
\text { performance, que não são registradas. }\end{array}$ \\
\hline Artefatos-Ostensivo & $\begin{array}{l}\text { - Ostensivo com gestão prejudicada e desalinhamento entre áreas. O processo } \\
\text { centralizado de compras desconsidera as compras que não seguem padrões tradicionais } \\
\text { (grandes lotes, ampla cadeia de fornecedores, materiais simples). } \\
\text { - Artefatos alinhados para cumprir regras em detrimento de outras necessidades. } \\
\text { Ausência e inadequação de artefatos. }\end{array}$ \\
\hline
\end{tabular}

Fonte: Elaborado pela pesquisadora a partir da análise das interrelações das partes da rotina

Sendo assim, a análise da categoria "relacionamento entre os aspectos ostensivo, performativo e artefatos" aponta que há oportunidade de melhoria das rotinas a partir das performances de compra da área técnica, as quais foram adaptadas para cumprir a necessidade de atendimento de prazo de compras, além de estarem dentro dos preceitos legais. Porém, ainda não houve alteração no aspecto ostensivo e nos artefatos, provocando um desalinhamento entre as partes da rotina organizacional de compras, que dificulta inclusive, sua gestão. Portanto, como as rotinas organizacionais de compra não seguem a lógica de um sistema generativo que promova a dualidade entre a estrutura (padrões) e ação (performances), logo, não existe o dinamismo simultâneo que promova a estabilidade e a flexibilidade dos padrões de acordo com a necessidade do contexto (FELDMAN e PENTLAND, 2008; FELDMAN e PENTLAND, 2005). Isto posto, entende-se que há necessidade de maior dinamismo para a alteração endógena da rotina de compras. 


\section{4.}

\section{Transferência de conhecimento sobre a rotina organizacional}

A intenção desta categoria foi a de investigar como acontece a transferência de conhecimento sobre as rotinas organizacionais de compra, tanto para as equipes participantes, quanto para a empresa, considerando que as rotinas são elementos importantes do conhecimento organizacional (FELDMAN, 2000), mas nem sempre são fáceis de transferir (PENTLAND e FELDMAN, 2005; DARR e ARGOTE, 1999 in PARMIGIANI et al., 2011). Argote e Ingram (2000) afirmam que a transferência de conhecimento pode ser medida a partir da mudança do conhecimento e da mudança da performance organizacional. Neste sentido, entende-se que a variação aconteceu, mas não foi transferida para a área de compras, ratificando a imaturidade e a resistência do processo de transferência de conhecimento.

As rotinas organizacionais investigadas estão formalizadas a partir de normas e instruções operacionais. A área de processos institucionais, participante desta pesquisa, é a responsável por organizar, publicar, manter e atualizar esses documentos, que devem estar disponíveis na intranet da empresa para consultas de todos os colaboradores da "Organização S". Porém, a própria área admite a dificuldade em controlar a efetividade dessas rotinas e entender quais etapas exigem melhorias (ARGOTE e IMGRAM, 2000; PENTLAND et al., 2012). Os comentários a seguir refletem esse problema e apontam como está planejada a transferência de conhecimento sobre as rotinas, falando especificamente do projeto de melhorias das rotinas de compra que está em andamento:

Apesar de nós temos acordo de nível de serviço, com prazos estabelecidos para a realização das compras, nós não temos como tirar esses dados do sistema...eu só tenho como contabilizar o tempo da compra do produto do início e do fim do processo, mas não tenho como contabilizar os tempos intermediários de cada tarefa de compra.

A transferência de conhecimento desses novos processos para a empresa como um todo já está dentro do escopo do projeto...a gente reúne a equipe do projeto, envolve o RH e a Comunicação,[...] então a gente começa a pensar no que que precisa ser treinado em termos de sistema físico, em termos de processo, como é a comunicação dos temas do processo, o que disso pode ser visual, o que tem que ser descritivo, o que é pode ser em $E A D$, o que a gente precisa garantir através de uma prova, uma avaliação[...]. (Entrevista P1)

Alguns apontamentos das entrevistas da equipe da área de compras remetem à transferência de conhecimento sobre as rotinas de compra, não sendo observado alinhamento entre o discurso dos atores de compras: 
[...] há treinamento formal das pessoas...pelo menos uma vez por ano, por acaso há 20 dias eu fiz um treinamento com toda a área[...] pego toda gerência, pelo menos uma vez por ano e dou uma reciclada, um freio de arrumação[...] por mais treinamento de gente faça, infelizmente alguns profissionais são levados a serem quase como tiradores de pedido. (Entrevista C1)

Quando contrato um novo colaborador para minha área, um novo comprador, nos primeiros 15 dias a gente coloca ao lado de um profissional já mais experiente, para que possa passar parte do conhecimento para ele. (Entrevista C2)

[...] existe um treinamento específico, desde a recepção do novo colaborador, os preceitos do RH, imediatamente é destacado um colaborador do seu mesmo nível, e o coordenador que o acompanhará durante 15 dias...a gente sempre escolhe pessoas com experiência...o que ele precisa aprender são os sistemas... estamos sempre fazendo treinamentos periódicos, passando instruções por e-mail. (Entrevista C3)

Não há um tempo fixo para treinar, pois alguns pegam mais rápido e outros não. À medida que a gente vê que a pessoa consegue andar sozinho a gente dá liberdade para ela trabalhar[...].(Entrevista C4)

[...]não foi indicado treinamento específico para o almoxarife, apenas relacionados NBR que devem ser cumpridas...não sei se existe necessidade de reciclagem [...].(Entrevista C5)

No momento o meu treinamento é mais virtual, à distância. Tem uns cursinhos de aperfeiçoamento, desde Excel, Office, até logística. Faço todo o ano. (Entrevista C6)

Sou formada em Administração e Logística e sempre trabalhei nessa área, logo, sei comprar. Quando eu cheguei aqui eu sentei ao lado de um comprador para que ele me passasse as informações...estou aqui há dois anos e meio nós só tivemos dois treinamentos... um foi de negociação e o outro foi para falar sobre o nivelamento de processo. (Entrevista C7)

Eu aprendi a fazer o processo de compra com a ajuda dos universitários. O meu supervisor, quando eu cheguei, fiquei um tempo lá com ele...uns 3 ou 4 meses [...]. Eu até falo que eu deveria ter ficado um pouco mais porque eu ligava muito para eles, porque eu tinha muitas dúvidas [...].(Entrevista C8)

A área técnica aponta a ausência de uma referência na área de compras, um comprador que eles possam oferecer treinamento para a compra de insumos. A memória e o conhecimento sobre a compra não são mantidos na área, apesar da área técnica já ter treinado um comprador anteriormente. Os seguintes apontamentos foram feitos pela área técnica em relação à transferência de conhecimentos sobre as rotinas de compra:

Quero muito fazer uma parceria com eles, para poder participar da construção do processo de compras, falando sobre todas as especificidades das nossas compras [...] que são coisas não triviais que fogem do receituário [...]. (Entrevista T1) 
Para passar o conhecimento de produtos químicos para se conseguir fazer a compra [...] é necessário sentar junto com as pessoas que fazem a compra, que já tem os contatos, apesar de já termos passado os contatos dos fornecedores, a forma de lidar com esses fornecedores, os macetes, entender a lábia que dos caras [...] são coisas muito específicas [...] os compradores precisam saber se as informações procedem [...] para passar essas informações só sentando junto com as pessoas que fazem a minha compra para conseguir fazer [...].(Entrevista T2)

Uma vez quando nós tínhamos um comprador nós treinamos e depois eles nos tiraram. Esse comprador participava das nossas reuniões de coordenação. O cara chegou sem saber nada e no final ele sabia tudo. Depois tiraram ele e mandaram para outra unidade [...] tivemos a maior trabalheira com ele. (Entrevista T3)

Cada hora uma pessoa diferente iniciava e a gente passava todas as informações, aí o cara ia embora, pedia demissão e aquele histórico não ficava [...] acontece isso com compras, pois várias vezes a gente treinou e ensinou o comprador, $e$ quando ia passar a demanda não encontrava mais a pessoa [...] e diziam que agora mudou e aquela fulana não está aqui. Eu digo, gente, cadê aquele histórico? Então, a memória, a história não fica na área, e eu não sei o que acontece [...].(Entrevista T4)

A iniciativa para aumentar a interação com a área de compras para melhorar o conhecimento sobre o processo partiu daqui. (Entrevista T5)

Nunca participei de treinamento com a área de compras. O que a gente participou foi quando eles nos chamaram para explicar o processo deles, como que é. Isso foi esse ano [...].(Entrevista T6)

Nunca participei de nenhum treinamento com a área de compras durante os três anos que eu tenho de empresa. (Entrevista T7)

A participação do técnico nos treinamentos de compras, passando este conhecimento teórico sobre os produtos, ajudaria bastante a área de compras. (Entrevista T8)

Um aspecto relevante sobre a transferência de conhecimentos é o sistema utilizado pela empresa, o qual deveria ser um repositório de informações para apoiar a equipe de compras (BECKER, 2004). Ainda assim, todas as informações sobre a compra de insumos estão devidamente registradas no sistema conforme aponta um ator da área técnica "[...] não existe mais nada, agora com o ERP então, não existe mais nada que não esteja no sistema [...]" (entrevista T1). Entretanto, a área técnica tem restrição de acesso ao sistema e reitera que há intermediários para seu uso "nós não temos interface com o sistema ERP, é o administrativo que faz isso pra nós" (entrevista T6). Como já apontado, este sistema não permite o registro de informações obtidas a partir da performance da rotina, impedindo a construção dos artefatos fundamentados no aspecto performativo. Além disso, as informações sobre o consumo anual, uteis para o planejamento das compras, não são utilizadas, uma vez que apenas as 
compras que passam no estoque servem a este propósito. Estes pontos dificultam a utilização da sociomaterialidade para a disseminação dos conhecimentos, através da construção coletiva do material e social que trazem implicações para a prática organizacional (LEONARDI, 2012; LEONARDI et al., 2012; ORLOKOWSKI, 2007; HILARICUS, 2011). Os comentários a seguir evidenciam estes problemas:

O sistema que me apoia é o ERP que não tem um campo onde a gente possa anotar nada. Eu nem posso inserir nada, pois isso é da área de cadastro. Se eu tiver alguma observação eu tenho que falar para eles...a orientação é que qualquer problema seja relatado por e-mail para a área de cadastro e essa informação fica na caixa de e-mail deles, pois não vai para o sistema ou não é utilizado para mais nada...quando o fornecedor não entrega um material nós devemos informar ao cadastro, pois eles precisam notificar o fornecedor, questionando sobre o porquê da entrega não ter sido realizada dentro do prazo. (Entrevista C8)

Outro dificultador para a transferência de conhecimentos sobre as rotinas de compra é a comunicação das áreas, que não é considerada efetiva pelas áreas técnica e de compras. Este aspecto é transversal às categorias de transferência de conhecimento e integração entre equipes e, Feldman e Rafaeli (2002), argumentam que as conexões entre pessoas ajudam no entendimento sobre o que é necessário fazer em um momento específico de uma rotina organizacional. Os comentários a seguir indicam algum tipo de problema de comunicação:

A área de compras tem uma estrutura muito verticalizada, tem muitas caixinhas, tem o chefe do chefe do chefe, isso atrapalha muito [...] a comunicação é muito formal [...] até uns 6 meses atrás [...] eu recebia os processos pelo malote e a área de compras fica num andar acima do meu [...] esse malote com os meus processos ia lá para a sede, na Cinelândia, para depois vir para cá, na Tijuca [...] às vezes, estávamos morrendo de pressa e o processo pedia só o meu "de acordo", isso demorava 3 ou 4 dias. (Entrevista T1)

A área de compras nunca nos pediu nossa listagem de fornecedores, mas nós encaminhamos junto com a listagem de materiais a serem comprados [...]. (Entrevista T2)

[...] tem algum processo da área de compras que eu acho que mudam lá pra eles e a gente não fica sabendo. Na hora que o nosso processo chega lá fica no gargalo e depois que a gente descobre o que aconteceu [...].(Entrevista T3) 
Portanto, a memória organizacional que poderia ser acumulada, estocada, aplicada e transmitida para construir um reservatório de conhecimento, não está acontecendo nas rotinas organizacionais de compras da "Organização S", conforme preconizam os teóricos (NELSON e WINTER, 1982; LEVITT e MARCH, 1988; MCGRATH e ARGOTE, 2001; GOUSSEVSKAIA et al., 2005). A aprendizagem organizacional, neste sentido, fica deficitária, pois um dos ativos chaves da empresa, o conhecimento, não está sendo utilizado para criar valor e gerar vantagem competitiva (ARGOTE, 2003; BARNEY et al., 1991; ARGOTE e INGRAM, 2000; FRIESL e LARTY, 2013; PARMIGIANI et al., 2011).

Para resumir esta categoria, verificou-se que o conhecimento sobre as rotinas organizacionais é construído de forma individual e não coletiva, desconsiderando a contribuição de cada participante e prejudicando o fluxo sequencial das tarefas. Além disso, as informações não são bem disseminadas para as equipes através de um processo sistematizado e estruturado. Algumas informações só chegam para as equipes se elas buscarem por sua própria vontade, dependendo muito mais de relacionamento do que de processo estruturado. A falta de memória e histórico das rotinas organizacionais de compra de insumos químicos corrobora a dificuldade da área de compras em prover a "transferência de conhecimentos". De acordo com as constatações avaliadas, a variação da rotina pode estar sendo estimulada pela dificuldade das pessoas da área de compras comprarem insumos químicos, justamente por não terem conhecimento.

\section{5 .}

\section{Integração inter e intra áreas e equipes}

Nesta categoria houve interesse no entendimento sobre a integração dentro das área e entre áreas e o primeiro ponto de atenção foi a constatação de uma possível falta de integração dentro da área de compras. A área é dividida em subáreas de acordo com a sua especialização e função no processo o que é natural para o controle do trabalho. Porém, suas atividades são desconectadas e os participantes não denotaram parceria, dificultando o processo social e a transferência de informações (FELDMAN e RAFAELI, 2002). Os comentários a seguir ajudam a ilustrar esses acontecimentos: 
A gente tem problema com valores estimados, evidência de preço, com especificação. Esses são problemas alheios a setor de compras...ir nas unidades para pedir o planejamento não é função da minha área, pois tem uma área exclusiva para isso [...]. Há duas pessoas do Setor de cadastro que só fazem esse trabalho diariamente. Em relação ao planejamento de compras eu participei indiretamente em um projeto com a área de materiais onde ela teve que levantar todos os grupos de materiais, material estocável e fazer uma solicitação com previsão para um ano. Até agora não precebi melhora no planejamento. Já tem dois anos que as visitas técnicas de planejamento acontecem.” (Entrevista C3)

$\mathrm{Na}$ realidade nós não compramos nada, nós planejarmos os materiais $e$ encaminhamos o setor de compra para seguir todo o trâmite. Na essência nós não chegamos ao detalhe de conhecer o uso e a importância dos insumos de metrologia para o "Instituto A” [...] (Entrevista C4)

$\mathrm{Na}$ área técnica há uma área administrativa que busca agrupar as compras necessárias aos laboratórios, evitando a duplicidade de solicitações do mesmo produto. Antes desse processo ser estabelecido, havia muita duplicidade de compras, pois os laboratórios trabalham de forma independente, logo, as compras também eram desconexas. Contudo, ao mesmo tempo em que a área administrativa apoia a rotina de compra, acaba executando um papel de intermediário, filtrando todas as solicitações de informação passadas pela área de compras. Quando este administrativo não consegue resolver os problemas, por se tratar de alguma informação técnica, abordam os técnicos. Este processo foi instituído com o intuito de evitar interrupções no trabalho dos técnicos, mas seu efeito colateral é trazer morosidade ao processo. Ainda assim, Feldman e Rafaeli (2002) apontam o compartilhamento de entendimentos como uma importante ferramenta para orientar as ações individuais.

Outra questão sobre a falta de integração intra área está associada a uma perspectiva cultural que envolve a empresa inteira, que diz respeito à hierarquia preconizada pela organização. O comentário abaixo reflete bem esse aspecto:

Se um técnico pede o auxílio de outro técnico, para o bem do trabalho, nada acontece. Se um analista pede, ou o especialista, ou o chefe, aí funciona. Isso não tem que ser assim. Independente da hierarquia eu tenho que ter um dever. (Entrevista T5)

A falta da integração entre as áreas de compra e técnica também foi observada durante essa pesquisa, com comunicação pouco efetiva, baseada em e-mail, com pouquíssimos comandos de informações via sistema. Além disso, não constroem as rotinas de forma compartilhada, muito embora a rotina seja distribuída no tempo e no espaço entre as duas áreas (FELDMAN, 2003). Partem do princípio que, 
"Se algo der errado na compra dos insumos, a responsabilidade é de quem não especificou os produtos de forma clara. E também não planejou com antecedência." (Entrevista C2)

O resultado dessa prática é o não entendimento mútuo sobre a necessidade das áreas. A afirmação de que a área de compras não consegue comprar sozinha é o slogan ouvido da área técnica. A afirmação de que a área técnica não consegue planejar sua compra é a justificativa da área de compras. Ambas afirmativas podem estar associadas ao desconhecimento das necessidades de cada área, impelidas pelo fato da desintegração entre si. E, considerando as rotinas como um processo de formação coletiva, embora sugiram uma perspectiva individualista, dependem de atitudes cognitivas e motivacionais dos participantes para que possam acontecer (WITT, 2011). Alguns comentários, embora não exaustivos, comprovam essa questão:

"Buscar informações do processo que ocorre no "Instituto A" é o mais penoso para a gente...o problema é que há uma visão imediatista” (Entrevista C1).

"Efetivamente a atividade fim do "Instituto A" eu conheço muito pouco" (Entrevista C5);

"[...] Não sei informar a consequência da compra desses materiais...não consigo avaliar se os processos atuais de compra são adequados para o "Instituto A" (Entrevista C7).

"A máxima da área de compras é sempre fiz assim então eu sei como funciona" (Entrevista P1).

Outro ponto abordado durante as entrevistas foi sobre haver integração entre as duas áreas a fim de buscar soluções conjuntas para a melhoria das rotinas, com treinamentos, seminários, elaboração de novas rotinas. Foi observado certo conflito de interesses que prejudica a interação no ambiente organizacional e amplia o potencial de desacordo (NELSON e WINTER, 1982). Porém, a área técnica correspondeu positivamente, demonstrando comprometimento, embora acredite que deva haver uma iniciativa da área de compras. Contudo, foi observado certo incômodo ou reação negativa em alguns atores da área de compras:

[...] a participação da área técnica no treinamento da área de compras [...] (silêncio) [...] (gaguejos) é possível, mas [...] só tem que tomar um cuidado pois, nós temos compradores generalistas que atendem a toda a empresa. Não existe dedicação de compradores a determinada área...fazer treinamento junto com área técnica não é fundamental, porque se eu tenho um planejamento, se eu tenho uma ficha de especificação de material e se eu tenho mercado mapeado...qualquer um faz o processo de aquisição. (Entrevista C1) 
Quando o profissional de compras começa, o supervisor o leva às áreas que ele vai atender, para ter mais interação com a área, conhecer as pessoas com quem vai lidar, conhecer o material, alguns fluxos. Justamente para isso...o próprio supervisor visita as áreas, para detectar problemas que a área seja identificando em relação ao atendimento, colher sugestões, a gente faz relatório dessas visitas. (Entrevista C3)

Por último, a questão da desintegração afeta a relação da área de compras "além muros". A relação da área com os fornecedores parece ser bastante distante. O mercado de químicos é bastante restrito, pulverizado e especializado, sendo difícil concentrar em um único fornecedor a compra de todos os insumos, justamente por esta peculiaridade da cadeia de suprimentos. O desconhecimento da área de compras em relação às características dos fornecedores, denota desintegração desta área com sua função primária, cujas rotinas não reduzem a incerteza e insegurança do comportamento da compra (FELDMAN, 2003; RERUP e FELDMAN, 2011; NELSON e WINTER, 1982).

Se a área de compras pretende esperar juntar 44 mil em reagentes para abrir um processo de licitação e comprar de uma única vez, mesmo para uma previsão de 6 meses...teria que juntar muito...muito...”; "aqui a gente não qualifica o fornecedor, consultamos e pronto, compramos."; "hoje os meus técnicos sabem comprar, conhecem bem os fornecedores e fazem isso rapidamente"; " $E$ necessário saber trabalhar com a vantagem e desvantagem de ter um número restrito de fornecedores. (Entrevista T2)

As rotinas organizacionais precisam servir a funções mais ou menos eficazes para serem suficientes para beneficiar os objetivos da organização e provocar a integração nos participantes. Em geral, as rotinas emergentes do contexto, embora assumam uma importância estratégica menor para a empresa, provocam boa parte das interações entre os participantes, pois são construídas a partir dos ditos sistemas generativos (WITT, 2011; FELDMAN E PENTLAND, 2005). Portanto, a disponibilidade para a "integração inter e intra áreas e equipes" deve vencer uma barreira cultural que permeia a organização como um todo. As áreas acusam uma à outra de não ser partícipe do processo, mas a exploração desta categoria deixa claro o entendimento sobre a falta de parceria, cooperação e corresponsabilidade, com iniciativas conjuntas e estruturadas para as transformações necessárias à rotina de compras, o que certamente fomenta a variação das rotinas. 


\section{6.}

\section{Variação das rotinas organizacionais, implicações e tratamento}

Esta categoria buscou analisar as principais variações das rotinas de compra de insumos químicos, suas implicações para a empresa e o tratamento para mitigar essas variações, sendo que, as variações nas rotinas podem acontecer em função de crises ou aspectos exógenos, além de mudanças quando o ambiente está estável (FELDMAN, 2000). Feldman e Pentland (2003) apontam, também, que a variação da rotina organizacional acontece em função do poder de agência das pessoas que as performam, uma vez que a performance carrega um componente de improvisação (D'ADDERIO, 2011).

As rotinas de compras abordadas neste estudo vêm sofrendo variações há uns quatro ou cinco anos. Porém, ainda não se tratam de variações preconizadas por Pentland e Feldman (2003), oriunda de movimentos dinâmicos entre os aspectos performativos e ostensivos, que oferecem grandes oportunidades para melhorias desejáveis nas rotinas organizacionais provocando inovações. A variação inicial, que alavancou o estudo é a alteração de papéis dos participantes das rotinas, cuja performance deveria ser desempenhada por um participante, que não está conseguindo executá-la. Esta variação é prejudicial ${ }^{24}$ ao negócio do "Instituto A", porém, é indispensável à sua operação. A área de compras, pressionada pela performance dentro do regulamento, acaba apenas finalizando o processo de compras no sistema, já que está incapacitada de performar a rotina em função da obsolescência de artefatos e estrutura inadequada (COHEN, 2007; HANNANA e FREEMAN, 1983; WEIS e ILGEN, 1985; GERSICK e HACKMAN, 1990; ASHFORTH E FRIED, 1988).

Entre os componentes que permitiram esta variação estão fatores exógenos e endógenos (FELDMAN, 2000; FELDMAN e PENTLAND, 2003). Entre os fatores exógenos estão à mudança dinâmica nas especificações dos insumos químicos, o aumento por sua demanda e o comportamento da cadeia de fornecedores. O fato de não ter havido uma evolução simultânea e gradual do aspecto ostensivo e artefatos das rotinas de compra de insumos químicos fez com que a performance dessa rotina ficasse cada vez mais difícil de ser executada pelo seu respectivo responsável. As compras de insumos químicos eram programadas automaticamente e não havia o devido controle sobre o que

${ }^{24}$ O prejuízo se refere ao gasto de tempo da equipe técnica em atividades que não fazem parte das suas atividades fim, pois os técnicos que deveriam se dedicar ao trabalho das análises de bancada, acabam fazendo as compras de insumos químicos. 
era adquirido, constituindo uma irracionalidade na execução da rotina (PENTLAND e HAEREM, 2015; HANNANA e FREEMAN, 1983), pois a área de compras imaginava não haver alteração nas especificações técnicas dos insumos pelos fornecedores. Como resultado, os produtos não eram adequados para a prestação dos serviços de laboratório.

Nesse sentido, a área técnica passou a comprar os próprios insumos e, ao mesmo tempo que este fato gerou variação, trouxe elementos que proporcionaram a melhoria da rotina organizacional, que poderão ser incorporados às rotinas de compra, trazendo inovação para a empresa (FELDMAN, 2000). Por um lado, os artefatos ficaram cada vez mais desatualizados e inadequados para prover a realização da rotina pela área de compras. Por outro lado, o conhecimento tácito dos técnicos em química foi utilizado na busca por melhores fornecedores, com os quais se estreitou o relacionamento, além da inversão de algumas etapas do processo de compras, favorecendo a agilidade da compra. Neste sentido, o papel da agência dos participantes da rotina trouxe efetividade ao processo, uma vez que a subjetividade e o poder precisaram ser utilizados para apoiar a performance (HOWARD-GRENVILLE, 2005). Além disso, ficou claro que é necessário haver a comunicação efetiva entre os participantes da rotina (FELDMAN e RAFAELI, 2002), pois a racionalidade limitada apontada por Dosi, Nelson e Winter (2000) requer articulação, interação e troca de experiência entre os indivíduos. Ainda, para complementar, é necessária uma especialização mínima para a compra desses insumos, pois a troca constante de compradores é um dificultador para a construção da competência da compra e de um relacionamento sólido com os fornecedores e para o conhecimento sobre os itens de compra, já que esta prática não permite formar uma referência (SIMON, 1997). As práticas adotadas dentro deste contexto material e social (PENTLAND e HÆEREM, 2015) ganharam um caráter de interdependência que não havia na rotina original, formando uma rede de participantes ativos, implicando na efetivação da rotina de compra de insumos químicos, dentro do prazo previsto e de acordo com os preceitos legais.

Contudo, os novos padrões de compra adotados pela área técnica não foram difundidos para todos os participantes da rotina organizacional, deixando de formalizar a mudança endógena favorável e concentrando-se apenas na área técnica, já que a área de compras não possui estrutura adequada ou interesse para incorporar as alterações necessárias (PENTLAND e FELDMAN, 2005). Um dos atores da área de compras comenta sobre a variação na rotina de compras, sendo performada pela área técnica: 
"Em algumas áreas isso é muito exacerbado, o volume de ocorrências é muito grande...É tolerável que se receba esse processo pronto com certa frequência...o problema é quando se torna muito grande, e que pode estar causando prejuízo, seja ele prejuízo financeiro, seja ele riscos de auditoria (entrevista C1)”.

A variação das rotinas de compra sendo performadas pela área técnica trazem, também, implicações sérias ao negócio do "Instituto A". Os depoimentos a seguir ilustram algumas opiniões:

"A alternância de ator no processo de compras é péssima para organização porque há o risco do processo ser percebido como fracionado...pega um técnico que deveria estar produzindo para área técnica, para fazer compras que é administrativo...pode causar um desvio de função, pois este profissional administrativo pode estar recebendo um salário inferior ao do técnico que está fazendo a compra e isso caracteriza desvio de função...o fornecedor pode estar manipulando...certamente não está chegando ao melhor preço...nós não colocamos com uma instituição estruturada, ao contrário, estamos nos colocando como uma empresa com processos pulverizados... Eu acho péssimo." (Entrevista C1)

"O fato da gente comprar traz implicações...eu acho que é inapropriado, mesmo...é uma sobrecarga de trabalho, em vez de eu estar executando eu estou comprando. Então isso pra mim já compromete o trabalho. E existem os riscos de um técnico ter preferência por alguma outra empresa...se a gente trabalhar em parceria com a área de compras a gente minimiza isso." (Entrevista T1)

"Se pegar 40 técnicos em química, e cada técnico perder uma hora por semana com compras é como se eu perdesse um técnico do meu quadro o ano todo. Basta ele dispensar uma hora num processo qualquer de compra...é como se eu tivesse uma mão de obra minha a menos o ano inteiro, para uma atividade que é da área meio. (Entrevista T2)

Sobre o tratamento das variações, ainda não houve uma abordagem sistematizada, mas apenas algumas ações pontuais e paliativas. A área de compras garante que todas as compras estejam inseridas e finalizadas no sistema, mantendo o registro dos dados; além disso, há um projeto de melhoria das rotinas organizacionais de compra:

"No início desse ano (2015) a área de compras nos procurou para dar aos compradores um padrão com o objetivo de aumentar a agilidade deles [...] nessa época a gente não teve um olhar de transformação do processo, era uma padronização[...] g gente apontou algumas coisas que poderiam ser melhoradas, mas nada significativo [...] ]uma demanda institucional para olhar este processo como um todo [...] tem que trabalhar os comportamentos das pessoas[...] efetivamente buscar a causa raiz do problema[...] este é o escopo do projeto que está em andamento.” (Entrevista P1)

"Eu quero saber na hora da auditoria sobre o tratamento para a melhoria desse processo. Essas não conformidades são só comigo [...]? Isso vem melhorando ao longo dos anos ou está igual? Quero ver essa gestão. Embora, ela não seja minha, ela me impacta. (Entrevista T1) 
De forma compacta e aglutinada por tipo, o rol de variações, impactos e tratamento pode ser visualizado no Quadro 7.

Quadro 7: Variações das rotinas, impactos e tratamento

\begin{tabular}{|c|c|c|c|}
\hline $\mathbf{N}^{0}$ & $\begin{array}{l}\text { VARIACGÄO DA ROTINA } \\
\text { ORGANIZACIONAL. }\end{array}$ & IMPACTO & TRATAMENTO \\
\hline 1 & $\begin{array}{l}\text { Performance realizada pelo ator indevido } \\
\text { (compra feita pela área técnica, recebimento } \\
\text { das mercadorias idem, cotação e evidência } \\
\text { de preços ibidem) }\end{array}$ & $\begin{array}{l}\text { Perda de produtividade da área técnica e risco } \\
\text { organizacional; procedimento de vistoria pode } \\
\text { ser desconsiderado, estocagem inexistente. }\end{array}$ & $\begin{array}{l}\text { Projeto de revisão de rotinas de } \\
\text { compra em andamento }\end{array}$ \\
\hline 2 & Inversão de etapas da rotina de compras & Rapidez no processo de compra emergencial & Não observado \\
\hline 3 & $\begin{array}{l}\text { Descumprimento de etapas chaves das } \\
\text { rotinas (SA e SC nem sempre são abertas, } \\
\text { insumos não passam pelo estoque) }\end{array}$ & $\begin{array}{l}\text { Não gera banco de dados útil para o } \\
\text { planejamento; } \\
\text { Estoque está sempre deficitário e não há a visão } \\
\text { dos itens estocáveis; } \\
\text { Registro no sistema fica deficitário. }\end{array}$ & $\begin{array}{l}\text { Não observado ou paliativo. } \\
\text { A área de compras faz o processo } \\
\text { de compras no sistema apenas } \\
\text { proforma, depois da compra } \\
\text { realizada. }\end{array}$ \\
\hline 4 & \begin{tabular}{|l|} 
Algumas performances são realizadas, mas \\
não existe um aspecto ostensivo que a \\
suporte (negociação da entrega com o \\
fornecedor, qualificação de fornecedores pela \\
área técnica, acompanhamento do pedido \\
pela área técnica)
\end{tabular} & \begin{tabular}{|l|} 
Inicialmente o impacto é positivo, pois ele efetiva \\
a compra (rapidez na entrega do pedido, \\
fornecedores respondem mais rápido às \\
cotações, monitoramento da entrega dá \\
segurança à área técnica). Porém, não há \\
envolvimento da área que deveria performar. \\
\end{tabular} & Não observado \\
\hline
\end{tabular}

Fonte: Elaborado pela pesquisadora a partir das entrevistas, análise documental e observações. 


\section{6. \\ Considerações finais}

\section{1. \\ Conclusão}

Para ter sustentabilidade econômica e garantir a qualidade na prestação de serviços de tecnologia, o "Instituto A" persegue continuamente a busca pela eficiência na gestão empresarial e melhoria de seus processos. Entretanto, nos últimos quatro a cinco anos a equipe técnica tem realizado sua própria compras de insumos químicos, o que consiste em uma variação desta rotina organizacional. Este trabalho buscou embasamento na teoria sobre as rotinas organizacionais a partir da constatação da existência dessa variação na rotina, cuja consequência é o fomento à ineficiência na produtividade do negócio. Este fato legitima a relevância deste estudo a fim de apontar novos padrões para a melhoria da gestão.

A literatura considera que as rotinas organizacionais são capazes de apoiar e promover o desenvolvimento e a inovação na empresa, uma vez que elas consistem em elementos de coordenação, aperfeiçoamento contínuo, armazenamento e transferência de conhecimentos, servindo como um produto da aprendizagem organizacional (GOUSSEVSKAIA et al., 2005; ARGOTE, 2003). Por outro lado, também são reconhecidas como elementos de inércia e inflexibilidade (CYERT e MARCH, 1963; HANNANA e FREEMAN, 1983; WEISS e ILGEN, 1986; GERSICK e HACKMAN, 1990; ASHFORTH e FRIED, 1988). Ainda, priorizados neste trabalho, Feldman (2000; 2003; 2004), Feldman e Pentland (2003; 2008) e Pentland e Feldman (2005; 2007; 2008) apontam o comportamento duplo da rotina organizacional, que promove sua estabilidade e flexibilidade, por meio de mecanismos como o poder da agência do sujeito que a executa, bem como pelo seu esforço por manter os padrões. Os mesmos autores orientam sobre a necessidade da investigação da rotina a partir da abertura da caixa preta para o entendimento dos motivos que promovem sua variação. 
Considerando que as rotinas organizacionais devem ser analisadas com maior aprofundamento para a compreensão das suas variações, realizou-se uma pesquisa qualitativa, cuja metodologia abordada, um estudo de caso único, utilizou múltiplas fontes de dados como entrevistas com 18 pessoas, a partir de um roteiro semiestruturado, a observação empírica da performance das rotinas de compra, a observação dos aspectos gerais das áreas envolvidas, além da análise de mais de 30 artefatos. A participação de dois atores neutros trouxe a oportunidade da visão imparcial para a análise, garantido a minimização de vieses. A escolha dos sujeitos também foi embasada na abordagem da visão de pessoas de vários níveis hierárquicos para garantir a diversidade de relatos.

A triangulação dos dados proporcionou a análise cruzada de fatos e permitiu um olhar para outras perspectivas, que possibilitaram a visualização de novas dimensões de variação para a mesma rotina, enriquecendo a compreensão, contribuindo para a validação da pesquisa e ratificando os conhecimentos sobre a teoria. Sendo assim, a partir das seis categorias analisadas na triangulação ("alinhamento de papéis, conceitos e interesses", a "estruturação e fundamentação das rotinas"; "relação entre as partes das rotinas"; "transferência de conhecimentos"; "integração das áreas e equipes"; "variações das rotinas, implicações e tratamento") foi possível obter alguns achados fundamentais que podem explicar e responder a questão de pesquisa, cumprindo o objetivo proposto de compreender os fatores que motivam as variações nas rotinas de compra de insumos para um instituto de tecnologia e inovação. Dentre as variações encontradas estão algumas performances realizadas pelo ator indevido, a inversão de etapas chaves da rotina, o descumprimento de etapas e as performances de atividades não previstas pela rotina. O resumo das variações e os seus fatores motivadores está apresentado no Apêndice $C$ deste documento.

Os resultados obtidos sugerem algum desalinhamento de interesses e necessidades entre a área de compras e a área técnica, pois as compras de insumos químicos devem se adaptar ao padrão institucional, com compras de grandes volumes a partir de processo licitatório, independentemente de suas peculiaridades. Além disso, o conceito da compra de insumos químicos adotado pela área de compras, não está alinhado dentro da própria área de compras. 
Ademais, as variações também são motivadas pela estrutura das rotinas de compra, totalmente baseada na compra de produtos padronizados, comuns e estocáveis por longos períodos de tempo, cuja cadeia de fornecedores é ampla e conhecida. O objetivo proposto por esta estrutura é o cumprimento das regras de compra a partir da modalidade de licitação, o que contradiz as especificidades da compra de insumos químicos. Impelida pela dificuldade no provimento de insumos para a prestação dos serviços, a equipe técnica do "Instituto A" vem articulando sua própria compra, provocando variações na performance da rotina. Por outro lado, estes novos padrões podem ser incorporados pela área de compras, a partir de uma estrutura dedicada às compras incomuns, com rotinas adequadas ao bom desempenho do negócio.

Também, verificou-se a necessidade de dinamismo na relação entre os aspectos ostensivo e performativo da rotina de compra, pois os artefatos requerem ajustes e adaptações para poderem apoiar as performances ou representar a ideia geral da rotina, sem a necessidade de variação na rotina organizacional. Portanto, não há a alteração endógena e incremental promovida pela relação dinâmica e fluida entre os aspectos da rotina. Os recursos exógenos têm limitado ainda mais a estruturação adequada das rotinas de compra (resultados apontados na auditoria) e, outros, são meramente desconsiderados pela área de compras para a reestruturação (aumento da demanda por serviços, característica e descrição dos insumos químicos e cadeia de fornecedores), embora tenham sido considerados pela área técnica.

Ainda, as perspectivas de comunicação e a relação de parceria requerem melhorias para facilitar a integração entre as áreas envolvidas e dentro da própria área de compras. Ficou claro que a transferência de conhecimentos não acontece de forma estruturada e sistemática, corroborada, principalmente, pela falta de memória organizacional para a compra de insumos químicos. O ostensivo, artefatos e performativo defasados não servem como repositório e transferência de conhecimentos.

A contribuição desta pesquisa para a teoria está, principalmente, ligada à convergência dos resultados encontrados com os pressupostos teóricos de Feldman e Pentland. O mecanismo do poder do agente é imprescindível para a adaptação da rotina na hora de sua performance, sempre que o contexto exigir. Esta nova performance produz um resultado aderente ao pretendido, promovendo uma variação, que pode ser incorporada à rotina, gerando uma inovação no processo para a melhoria dos resultados; ainda assim, o agente se esforça por manter os padrões de compra preconizado pelo regulamento interno 
de compras, cujas regras precisam ser seguidas em função das auditorias. O fato da observação direta da performance ter acontecido dentro do contexto organizacional é relevante para a teoria, pois há pouca pesquisa com observações empíricas das performances da rotina organizacional, sendo que a maior parte foi realizada a partir de simulações fora do ambiente organizacional real.

Contudo, embora alguns autores considerem que a mediação de disputas e redução de incertezas são papéis das rotinas, observou-se certo impasse ou conflito entre as áreas de compras e técnica, uma vez que a área de compras insiste em realizar a compra a partir de grandes quantidades, necessitando de um "planejamento" que não existe ou não pode ser totalmente previsto pela área técnica. Além disso, os dados empíricos comprovaram que as rotinas de compra atuais causam grande incerteza na área técnica, justamente por estarem desalinhadas das suas necessidades. Esses dois apontamentos, contrariam os preceitos teóricos de Nelson e Winter (1982) e Rerup e Feldman (2011), indicando que não basta ter uma rotina para evitar conflito e promover segurança, mas ela deve estar alinhada às necessidades do contexto e ser útil para o que se propõe.

Finalmente, para a empresa, este trabalho oferece uma autorreflexão fundamental no sentido de avaliar as divergências e a relação entre os aspectos ostensivo, performativo e artefatos das rotinas, apontando a necessidade da adaptação das rotinas ao contexto dos negócios, entendendo que há circunstâncias adequadas para as rotinas ficarem estáveis ou gerarem flexibilidade. Reconher a possibilidade dual da rotina em se manter estável e flexível, dentro do contexto, e permitir que essa relação dinâmica aconteça é essencial para originar a capacidade de promover a mudança endógena e incremental, preconizada pela teoria e corroborada por esta pesquisa. Então, à medida que houver a variação, seleção e retenção das novas práticas nas rotinas oficiais da empresa esta nova postura proverá a oportunidade da empresa obter desempenho superior nas compras corporativas, ganhando vantagem competitiva e inovando em seus processos, uma vez que a inovação é definida como novas combinações de rotinas existentes (PARMIGIANI et al., 2011; MINTZBERG et al., 2000). 


\section{2.}

\section{Limitações e pesquisa futura}

O fato dessa pesquisa ter sido desenvolvida por uma colaboradora da "Organização S" pode ter trazido limitações à pesquisa, pois os entrevistados podem ter restringido suas contribuições a fim de manter o zelo pela aparência das rotinas e de sua área. Outro aspecto limitante foi a escolha dos sujeitos da área de compras, cuja autorização era necessária para que participassem da entrevista. Portanto, alguns atores como supervisores, analistas, assistentes ou outros compradores poderiam trazer informações relevantes que não foram consideradas.

A observação dos aspectos performativos pelos participantes da rotina, principalmente pela área de compras, foi limitada a apenas algumas ações enquanto as entrevistas eram realizadas, uma vez que as pessoas estavam no seu local de trabalho. Esta observação teria trazido muita riqueza aos dados, além da oportunidade da comparabilidade das performances realizadas pela área técnica. Porém, esta análise ampliaria muito o escopo da pesquisa, sendo mais adequado sua aplicação em pesquisas posteriores, com foco mais restrito a poucas performances.

O aspecto ostensivo foi apresentado de forma desestruturada pelos participantes, trazendo a dificuldade do entendimento real e claro de como as rotinas organizacionais de compra estão estruturadas, mesmo com a presença dos artefatos. Os entrevistados falaram de alguns aspectos ostensivos que não pareceram necessariamente estruturados ou não são do conhecimento comum, além de não estarem fundamentados por artefatos. A limitação da pesquisa, nesse sentido, aconteceu em função do não entendimento, de fato, se o aspecto ostensivo existe ou se foi uma narrativa do entrevistado numa situação típica de stress e pressão.

Sobre a agenda de pesquisa futura é possível replicar este mesmo estudo de casos para outros institutos de tecnologia da "Organização S" ou em outros contextos organizacionais, como nas rotinas organizacionais da área comercial, da área de marketing, da área de pessoas, entre outras áreas. Além disso, é possível ampliar o olhar focando em alguns pontos obscuros destes achados, por exemplo, investigar o que é planejar para cada área e como seriam as partes dessa rotina, constatar se a qualidade da compra realizada por ambas as áreas é igual ou diferente. Enfim, temas que poderiam trazer ainda mais informações sobre como as rotinas organizacionais variam. 
Além disso, é possível investigar mais a categoria "transferência de conhecimentos sobre as rotinas" à luz de teorias específicas da gestão do conhecimento, amplamente difundidas na literatura. Esta abordagem permitiria a exploração de aspectos e dimensões não priorizadas nesta pesquisa. O mesmo poderia acontecer na categoria "integração inter e intra áreas e equipes", que pode ser melhor explorada em pesquisa futura, já que o objetivo proposto para esta pesquisa a partir deste tema era o entendimento genérico sobre a relação entre áreas e equipes. 


\section{7. \\ Referências bibliográficas}

ARGOTE, L. Introduction to the Special Issue on Managing Knowledge in Organizations: Creating, Retaining, and Transferring Knowledge. Management Science, 2003.

$\therefore$ INGRAM, P. Knowledge transfer: A basis for competitive

advantage in firms. Organizational behavior and human decision processes, $v$. 82 , n. 1, p. 150-169, 2000.

ASHFORTH, B. E.; FRIED, Y. The mindlessness of organizational behaviors. Human Relations, v. 41, n. 4, p. 305-329, 1988.

BAILY, P.; FARMER, D.; JESSOP, D.; JONES, D. Compras: Princípios e Administração. Editora Atlas, São Paulo, 2000.

BARNEY, J. B.; HESTERLY, W. S. Administração Estratégica e Vantagem Competitiva. $3^{a}$ edição. Pearson, 1991.

BECKER, M.; KNUDSEN, T. The role of routines in reducing uncertainty some empirical evidence. Academy of Management Conference, Washington, D.C., August 2001.

BICKMAN, L.; ROG, D. J. Handbook of applied social research methods. Thousand Oaks, Sage, 1997.

BIERNACKI, P.; WALDORF, D. Snowball sampling: Problems and Techniques of Chain Referral Sampling. Sociological Method Research. v. 10, p. 141 -163. 1981.

COHEN, M. D. Reading Dewey: Reflections on the study of routine. Organization Studies, v. 28, p. 773-786, 2007.

COHEN, W. M.; BACDAYAN, P. Organizational routines are stored as procedural memory: evidence from a laboratory study. Organization Science, Maryland, v. 5, n. 4, Nov. 1994.

et al. Routines and other recurring action patterns of organizations: contemporary research issues. Industrial and Corporate Change, Oxford, v. 5, n. 3, p. 653-698, 1996.

CRESWELL, J. W. Projeto de Pesquisa: Métodos Qualitativo, Quantitativo e Misto. Porto Alegre, Artmed, 2010.

CYERT, R. M.; MARCH, J. G. A Behavioral theory of the firm. 2. ed. Englewood Cliffs: Prentice Hall, 1963. 
D'ADDERIO, L. The performativity of routines: Theorising the influence of artefacts and distributed agencies on routines dynamics. Advanced Institute of Management Research (AIM), Technology Management Unit/SEE, Institute for the Study of Science, Technology and Innovation (ISSTI), The University of Edinburgh, United Kingdom, April 2008.

D'ADDERIO, L. Artifacts at the centre of routines: Performing the material turn in routines theory. Journal of Institutional Economics, v. 7, n. 2, p. 197-230, 2011.

DOSI, G.; NELSON, R.; WINTER, S. Introduction: the nature and dynamics of organizational capabilities. Oxford: Oxford University, 2000.

EMIRBAYER, M.; MISCHE, A. What Is Agency?. American Journal of Sociology, v. 103(4), p. 962-1023. 1998. Disponível em: $<$ http://doi.org/10.1086/231294>.

FELDMAN, M. S. A performative perspective on stability and change in Oganizational Routines. Industrial and Corporate Change, v. 12, n. 4, p. 727752. 2003.

Organizational Routines as a Source of Continuous Change. Organization Science, v. 11, n. 6,pp. 611-629. Nov-Dec. 2000.

Resources in Emerging Structures and Processes of Change. Organization Science, v. 15, n. 3, p. 295-309, May-June 2004.

$\therefore$ PENTLAND, B. T. Issues in Empirical Field Studies of Organization Routines. Handbook of Organizational Routines, 2008. ; Reconceptualizing Organizational Routines as a Source of Flexibility and Change. Administrative Science Quarterly, v. 48(1), p. 94118, 2003. ; Routine dynamics. In: BARRY, D.; HANSEN, H. (Eds), 2008. ; RAFAELI, A. Organizational Routines as Sources os connections and Understandings. Journal of Management Studies, May, 2002.

FRIESL, M.; LARTY, J. Replication of Routines in Organizations: Existing Literature and New Perspectives. International Journal of Management Reviews, v. 15, p. 106-122. 2013.

GEIGER, D.; SCHRÖDER, A. Ever-Changing routines? Toward a revised understanding of organizational routines between rule-following and rulebreaking. Shcmalenback Business Review. v. 66, p. 170-190. 2014.

GERSICK, C. J. G.; HACKMAN, J. R. Habitual routines in task-performing groups. Organizational behavior and human decision processes, v. 47, n. 1, p. 65-97, 1990.

GIDDENS, A. A constituição da sociedade. 2. ed. São Paulo: Martins Fontes, 1984.

GOODMAN, L. Snowball Sampling. In: Annals of Mathematical Statiscs, v. 32, p. 148-170, 1961.

GOUSSEVSKAIA, A.; MILAGRES, R.; ARAÚJO, A. L. L.; TELLO, R. Inovação interativa: capital social, knowledge sharing routines e formação de redes interorganizacionais. Nova Lima: Fundação Dom Cabral, 2005. 
GUENNIF, S.; MANGOLTE, P. Analysis of organizational routines: proposal for an analytical framework based on Nelson et Winter and Leibenstein. Paper presented to the Conference Empirical research on routines in business and economics: towards a research program, Odense, Nov. 2002.

HANNAN, M. T.; FREEMAN, J. Structural inertia and organizational change. American Sociological Review, p. 149-164, 1984.

HILARICUS, J. R. Toward a Sociomaterial Approach to Knowledgr Transfer. Ceregmia, Université des Antilles et de la Guyane Campus, 2011.

HODGSON, G. The Nature and Replication of Routines. The Business School, University of Hertfordshire, 2004.

HOWARD-GRENVILLE, J. The Persistence of Flexible Organizational Routines The Role of Agency and Organizational Context. Organization Science, v. 16, n. 6, 2005.

JONES, G. R.; GEORGE, J. M. Administração Contemporânea. Porto Alegre: AMGH, 2011.

LATOUR, B. The Powers of Association. In: LAW, J. (editor) Power, Action and Belief. A New Sociology of Knowledge? Sociological Review Monograph, Keele, p. 261-277, 1986.

LAZARIC, N. Organizational routines and cognition: an introduction to empirical an analytical contributions. Journal of Institutional Economics, Cambridge University Press (CUP), v. 7(2), p.147-156. 2011.

LEONARDI, P. M. Materiality, Sociomateriality, and Socio-Technical Systems: What Do These Terms Mean? How Are They Related? Do We Need Them?, Oxford: Oxford University Press, 2012.

LEONARDI, P.; NARDI, B.; KALLINIKOS, J. Materiality and Organizing Social Interaction in a Technological World, Oxford University Press, 2012.

LEVITT, B.; MARCH, J. Organizational learning. Annual Review of Sociology, Palo Alto, v. 14, p. 319-340, 1988.

MCGRATH, J.; ARGOTE, L. Group Processes in Organizational Contexts. Blackwell handbook of social psychology: Group processes. Oxford, UK: Blackwell, v. 3. 2001.

MILLER, K.; PENTLAND, B.; CHOI, S. Dynamics of Performing and Remembering Organizational Routines. Journal of Management Studies, v. 49:8, December, 2012.

MINTZBERG, H.; AHLSTRAND, B.; LAMPEL, J. Safari de Estratégia: um roteiro pela selva do planejamento estratégico. Porto Alegre, Bookman, 2000.

NELSON, R. R.; WINTER, S. G. An evolutionary theory of economic change. Harvard University Press, 1982. 
OLIVEIRA, M. M. Como Fazer Pesquisa Qualitativa. $3^{a}$ Ed. Petrópolis, RJ, Editora Vozes, 2010.

ORLIKOWSKI, W. J. Sociomaterial practices: Exploring technology at work, Organization Studies, v. 28, n. 9, p. 1435-1448. 2007.

PARMIGIANI, A.; HOWARD-GRENVILLE, J; Routines Revisited: Exploring the Capabilities and Practice Perspectives. Lundquist College of Business, University of Oregon, 2011.

PENTLAND, B.; FELDMAN, M. Designing routines- On the folly of designing artifacts, while hoping for patterns of action. Information and Organization, $p$. 235-250. 2008.

Narrative networks: Patterns of technology and organization. Organization Science, v. 18, n. 5, p. 781-795, 2007.

; _ Organizational Routines as Unit of Analysis. Industrial and Corporate Change, v. 14, n. 5, p 793-815, agosto, 2005.

.; H/EREM, T. Organizational Routines as Patterns of Action:

Implications for Organizational Behavior. The Annual Review of Organizational Psychology and Organizational Behavior. v. 2, p. 465-87. 2015. ; RUETER, $H$. Organizational routines as grammars of action.

Administrative Science Quarterly, p. 484-510, 1994.

et al. Dynamics of organizational routines: a generative model. Journal

of Management Studies, v. 49, n. 8, p. 1484-1508, 2012.

RAFAELI, A.; PRATT, M. G. Artifacts and organizations: Beyond mere symbolism. Psychology Press, 2013.

RERUP, C.; FELDMAN, M. Routines as a Source of Change in Organizational Schemata: The Role of Trial-and-Error Learning. Academy of Management Journal, v. 54, n. 3, p. 377-610. 2011.

SACHS, I. Caminhos para o Desenvolvimento Sustentável. Rio de Janeiro: Garamond, 2002.

SAFAVI, M. The role of multiple ostensive aspects in practicing change and stabilizing routines: A case study of a university merger. Presented in 35th DRUID Celebration Conference 2013, Barcelona, Spain, June 17-19.

SILVA, M. F. O. Grupos Estratégicos na Indústria Química Mundial: 20042008. BNDES Setorial Química, v. 33, p. 349-378, 2011. Disponível em: <https://web.bndes.gov.br/bib/jspui/handle/1408/1561>. Acesso em: 10/02/2016.

SIMON, H. A behavioral model of rational choice. Models of Man. New York: Wiley, 1957.

TURNER, S. F.; RINDOVA, V. A balancing act: how organizations pursue consistency in routine functioning in the face of ongoing change. Organization Science, v. 23(1), p. 24-46. 2012.

WEISS, H. M.; ILGEN, D. R. Routinized behavior in organizations. Journal of Behavioral Economics, v. 14, n. 1, p. 57-67, 1986. 
WITT, U. Emergence and functionality of organizational routines: an individualistic approach. Journal of Institutional Economics, v. 7, n. 2, p. 157174, 2011.

WHITTINGTON, R. Strategy Practice and Strategy Process: Family Differences and the Sociological Eye. doi:10.1177/0170840607081557. Organization Studies, v. 28(10), p. 1575-1586. 2007.

YIN, R. Estudo de Caso - Planejamento e Métodos, $2^{\mathrm{a}}$ Edição, Porto Alegre: Bookman, 2003. 


\section{APÊNDICE A - Lista de artefatos investigados}

\begin{tabular}{|c|c|c|}
\hline № & Nome do Artefato & Finalidade \\
\hline 1 & Regulamento de Compras A & Documento que regulamenta as compras de uma instituição da Organização $S$ \\
\hline 2 & Regulamento de Compras B & Documento que regulamenta as compras de outra instituição da Organização S \\
\hline 3 & Acordo de Nível de Serviço de Compras & Estabelece os prazos mínimos para a compra \\
\hline 4 & Macroprocessos de compra & Fluxograma macro das compras organizacionais \\
\hline 5 & Norma de aquisição de bens e serviços & Normatiza as compras institucionais \\
\hline 6 & Norma de cadastro de fornecedores & Normatiza o cadastro de fornecedores \\
\hline 7 & Norma de cadastro de produtos e serviços & Normatiza o cadastro de produtos e serviços \\
\hline 8 & Procedimento de solicitação de compras & Explica como é o processo de compras, seus responsáveis e papéis \\
\hline 9 & Procedimento de distribuição da demanda & Explica como as compras são distribuídas entre os compradores \\
\hline 10 & Procedimento de compras e aquisições & Explica os tipos de compras existentes na empresa e seus fluxos \\
\hline 11 & $\begin{array}{l}\begin{array}{l}\text { Procedimento de aquisição por dispensa de } \\
\text { licitação }\end{array} \\
\end{array}$ & Explica como fazer uma compra sem licitação \\
\hline 12 & Procedimento de aquisição por licitação & Explica como fazer uma compra com licitação \\
\hline 13 & Procedimento de compras por & Explica os casos possíveis de compra por inexigibilidade \\
\hline 14 & $\begin{array}{l}\text { Procedimento de emissão de parecer de } \\
\text { proposta de fornecedor }\end{array}$ & Orienta os responsáveis na avaliação das propostas de fornecedores \\
\hline 15 & Procedimento de importação de materiais & Explica como é o processo de compras de produtos importados \\
\hline 16 & Procedimento de cancelamento da compra & Explica como é o processo de cancelamento da compra \\
\hline 17 & Procedimento de recebimento de materiais & $\begin{array}{l}\text { Estabelece procedimentos para receber os materiais, lançar notas fiscais e emitir } \\
\text { notas fiscais de devolução. }\end{array}$ \\
\hline 18 & Ficha de Especificação técnica de materiais & É a ficha do cadastro do material dentro do sistema de controle de compras \\
\hline 19 & $\begin{array}{l}\text { Organograma da Gerência Geral de } \\
\text { Suprimentos }\end{array}$ & $\begin{array}{l}\text { É a estrutura da área de compras criada para atender as rotinas de compras } \\
\text { estabelecidas }\end{array}$ \\
\hline 20 & Fluxo de solicitações ao armazém & É o procedimento de solicitação de materiais estocados \\
\hline 21 & Fluxo de solicitações de compras & É o procedimento de solicitação de materiais quando não há estoque \\
\hline 22 & Planejamento de compras & É a listagem de materiais a serem adquiridos em um semestre \\
\hline 23 & Matriz de Problemas & $\begin{array}{l}\text { É o mapeamento de problemas da área de compras elaborado pela área de } \\
\text { processos }\end{array}$ \\
\hline 24 & Processo de compras paralelo & São as atividades de compras realizadas pela área técnica \\
\hline 25 & Check de recebimento do material & $\begin{array}{l}\text { É o checklist utilizado para verificar se o material entregue está em } \\
\text { conformidade com o pedido }\end{array}$ \\
\hline 26 & \begin{tabular}{|l} 
Nova ficha de solicitação de cadastro de \\
materiais
\end{tabular} & $\begin{array}{l}\text { É uma nova versão ainda não aprovada para o cadastro do material dentro do } \\
\text { sistema de controle de compras }\end{array}$ \\
\hline 27 & Lista de compras anual & $\begin{array}{l}\text { Registro do sistema de compras de todos os insumos químicos comprados } \\
\text { durante um exercício }\end{array}$ \\
\hline 28 & Cadastro de materiais e fornecedores & É a lista de materiais e fornecedores utilizada pelo "Instituto A" \\
\hline 29 & Dossiê de compras & É o arquivo físico da documentação de um processo de compra \\
\hline 30 & Módulo de compras do Sistema ERP & É o sistema que provê a automatização e controle das compras \\
\hline 31 & Evidência de Preço & É uma comunicação do fornecedor sobre o preço dos materiais ofertados por ele \\
\hline
\end{tabular}




\section{APÊNDICE B - Roteiro da entrevista}

$$
\begin{aligned}
& \text { Pontifícia U Universidade C Católica } \\
& \text { ROTEIRo dio daneiro ENTREVISTA SEMI ESTRUTURADA } \\
& \text { Entrevistado } \mathbf{n}^{\circ} \text { Cargo: } \\
& \text { Tempo de Experiência: } \\
& \text { Instruções de Aplicação: Conversar com o entrevistado sobre: }
\end{aligned}
$$

\begin{tabular}{|c|c|}
\hline Por que o local foi escolhido para o estudo? & $\begin{array}{l}\text { A área de compras é "guardiã" de rotinas organizacionais estratégicas } \\
\text { para o negócio do "Instituto A". }\end{array}$ \\
\hline $\begin{array}{l}\text { Quais atividades ocorrerão no local durante o } \\
\text { estudo de pesquisa? }\end{array}$ & $\begin{array}{l}\text { Entrevistas com roteiros semiestruturados com atores estratégicos no } \\
\text { processo de compras. }\end{array}$ \\
\hline O estudo será perturbador? & $\begin{array}{l}\text { Em absoluto. Será mantido sigilo de identidades, cargos e todo o } \\
\text { conteúdo ganhará caráter teórico, já que esta é uma proposta } \\
\text { acadêmica. }\end{array}$ \\
\hline Como os resultados serão relatados? & Em formato de relatório onde os assuntos serão categorizados. \\
\hline O que as pessoas ganharão com o estudo? & $\begin{array}{l}\text { Um estudo aprofundado à luz da teoria sobre a variação das rotinas } \\
\text { organizacionais da sua área e algumas possibilidades de melhoria, } \\
\text { caso sejam identificadas. }\end{array}$ \\
\hline Tema de pesquisa & $\begin{array}{l}\text { Variações em Rotinas Organizacionais: Um Estudo de Caso em um } \\
\text { Instituto de Tecnologia }\end{array}$ \\
\hline Delimitação do Estudo & Rotinas de Compras de insumos químicos para o "Instituto A". \\
\hline
\end{tabular}

Entrevistado $\mathrm{n}^{\circ} \_$_ Cargo:

\section{Tempo de Experiência:}

\section{BLOCO I: Sobre as áreas e os insumos}

Responsabilidades e necessidades das áreas no processo de compras.

O que é comprar insumos químicos?

\section{BLOCO II: Sobre as rotinas}

Estrutura das rotinas organizacionais de compra.

Fundamentação em artefatos.

Como elas acontecem? Quais são suas regras?

Quais são suas barreiras?

Há sugestão de melhorias?

\section{BLOCO III: Sobre o conhecimento das rotinas}

Transferência do conhecimento sobre as rotinas.

Existe treinamento? Como ele acontece?

Como as áreas estão integradas?

\section{BLOCO IV: Sobre as consequências da variação das rotinas}

Consciência sobre a variação das rotinas

Implicações da variação das rotinas.

Tratamento da variação das rotinas. 
APÊNDICE C - Variações das rotinas e justificativas 
Variações

1) Compra

realizada pela

área técnica

2) Recebimento de mercadorias pela área técnica

3) Área técnica realiza as cotações de compra

4) Inversão das etapas da rotina de compras

5) Evidência de preços é confundida com a Cotação de compras

6) Descumprimento de etapas chaves da rotina

7) Etapa do ostensivo não cumpre o seu propósito

8) Negociação do prazo de entrega

9) Acompanhament o do pedido

10) Qualificação/ desenvolvimento de fornecedores

\section{Fatores que motivam as variações (endógenos e exógenos)}

1) Necessidade de atendimento aos clientes com demandas emergenciais.

2) A estrutura da área de compras não possui uma rotina rápida e ágil para prove a compra de pequenos lotes de insumos.

3) A estrutura das rotinas de compra está adequada para a compra de insumos comuns que podem ser estocados por longos períodos e com número expressivo de fornecedores, cuja negociação é facilitada pelo poder de barganha da empresa.

4) Os aspectos ostensivo o os artefatos da rotina não apoiam a realização da compra pela área de compras, já que ficaram obsoletos ao longo dos tempos.

5) Área técnica utiliza conhecimento tácito para a realização da compra dos insumos químicos. A área de compras não tem demonstrado capacidade para produzir um repositório de conhecimento sobre a compra de insumos químicos.

6) Área de compras não se responsabiliza pela compra direta realizada pela área técnica.

7) Insumos comprados pela área técnica seguem direto para o consumo, sem passar pelo almoxarifado.

8) A área técnica realiza as cotações para agilizar a realização da compra, pois os prazos da área de compras, publicados no Acordo de Nível de Serviço, não são cumpridos.

9) A área técnica desenvolveu um bom relacionamento com o banco de fornecedores, que responde rapidamente aos pedidos de cotação de preços.

10) A área técnica inicia o processo de compras pela cotação, que é a parte mais lenta da rotina, já que depende da interação com o fornecedor. Enquanto aguarda o fornecedor responder, realiza as demais etapas do processo, buscando aprovação, abrindo a solicitação de compra, etc.

11) Antes de iniciar as cotações a área de compras se certifica que os fornecedores possuem regularidade fiscal, para não haver a perda do trabalho de cotar em fornecedor que está impedido de fornecer. Esta atividade faz parte da $5^{\mathrm{a}}$ etapa na rotina original, acontecendo após a cotação.

12) O processo de compras realizado pela área técnica preserva a relação de interdependência entre as ações e os atores, o que não é observado no aspecto ostensivo da rotina, com etapas quebradas e sem um responsável formal.

13) A Evidência de preço deve ser providenciada pela área técnica. Porém, é uma atividade similar à cotação de preços, que deve ser providenciada pela área de compras. Esta ambiguidade promove a variação, uma vez que a área técnica acaba recebendo várias respostas dos fornecedores e as utiliza para agilizar o processo.

14) Em caso de pressa para comprar a abertura da SA e/ou SC podem não acontecer e o pedido vai direto ao fornecedor.

15) SA não gera informações sobre os itens estocáveis, pois a compra direta não é considerada para tal.

16) SC é aberta após a compra ser efetuada, apenas para registro interno. Porém há alguns processos de compras que não são registrados.

17) Esta etapa não existe no aspecto ostensivo da rotina. Ela é realizada pela área técnica, que tem interesse em programar suas atividades. O próprio técnico entra em contato com o fornecedor assim que a solicitação de compra é aprovada, antes do pedido chegar no fornecedor, para que ele agilize a entrega, negociando o prazo.

18) Esta etapa não existe no aspecto ostensivo da rotina. Ela é realizada pela equipe técnica que tem interesse em saber quando o pedido chegará, cobrando justificativas do fornecedor em caso de atrasos.

19) Esta etapa não existe no aspecto ostensivo da rotina. Ela é realizada pela equipe técnica para manter um banco de fornecedores sempre atualizado, já que a cadeia de fornecedores de químicos é bastante dinâmica.

20) Os compradores da área de compras não são segmentados por tipo de produto e isso prejudica o relacionamento deles com os fornecedores, já que não gera uma referência. 


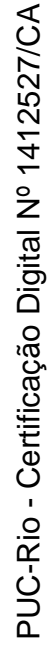




\section{ANEXO A - Processo Organizacional de Compras}

Processo Organizacional de Compras

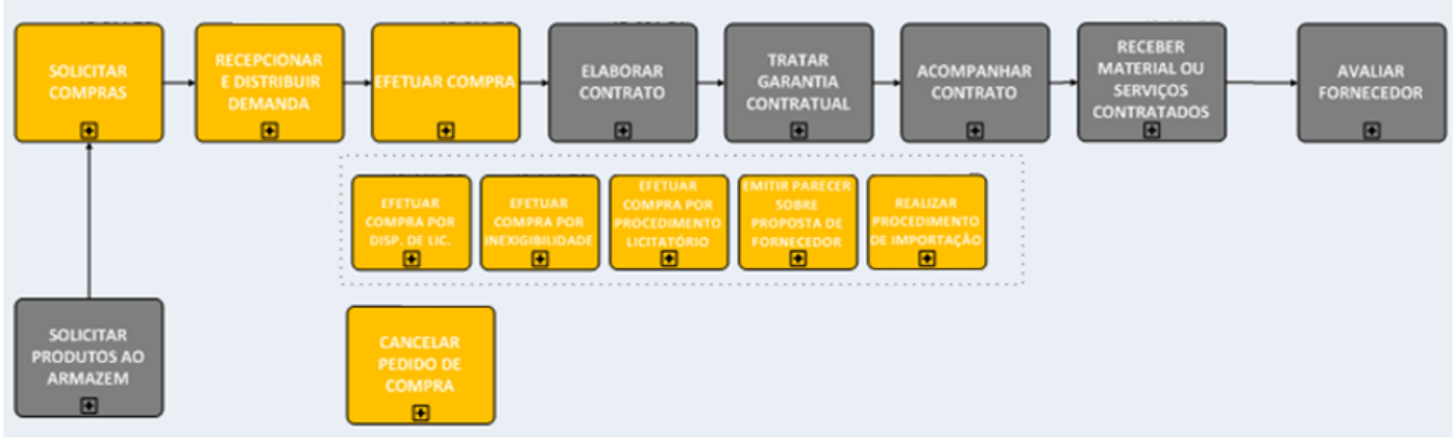

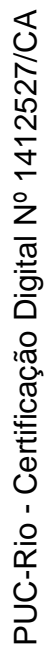

